Invited Review

\title{
Mineralogy and geochemistry of sedimentary rocks and eolian sediments in Gale crater, Mars: A review after six Earth years of exploration with Curiosity
}

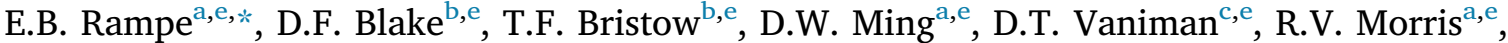 \\ C.N. Achilles ${ }^{\mathrm{d}, \mathrm{e}}$, S.J. Chipera ${ }^{\mathrm{c}, \mathrm{e}}$, S.M. Morrison ${ }^{\mathrm{e}, \mathrm{f}}$, V.M. Tu ${ }^{\mathrm{e}, \mathrm{g}}$, A.S. Yen $^{\mathrm{e}, \mathrm{h}}$, N. Castle ${ }^{\mathrm{e}, \mathrm{i}}$, \\ G.W. Downs ${ }^{\mathrm{e}, \mathrm{j}}$, R.T. Downs ${ }^{\mathrm{e}, \mathrm{j}}$, J.P. Grotzinger ${ }^{\mathrm{e}, \mathrm{k}}$, R.M. Hazen ${ }^{\mathrm{e}, \mathrm{f}}$, A.H. Treiman ${ }^{\mathrm{e}, \mathrm{i}}$, \\ T.S. Peretyazhko ${ }^{\mathrm{e}, \mathrm{g}}$, D.J. Des Marais ${ }^{\mathrm{b}, \mathrm{e}}$, R.C. Walroth ${ }^{\mathrm{b}, \mathrm{e}}$, P.I Craig ${ }^{\mathrm{c}, \mathrm{e}}$, J.A. Crisp ${ }^{\mathrm{e}, \mathrm{h}}$, B. Lafuente, ${ }^{\mathrm{e}, \mathrm{l}}$, \\ J.M. Morookian, ${ }^{\mathrm{e}, \mathrm{h}}$, P.C. Sarrazin ${ }^{\mathrm{e}, \mathrm{l}}$, M.T. Thorpe ${ }^{\mathrm{a}, \mathrm{e}}$, J.C. Bridges ${ }^{\mathrm{e}, \mathrm{m}}$, L.A. Edgar, ${ }^{\mathrm{e}, \mathrm{h}}$, C.M. Fedo ${ }^{\mathrm{e}, \mathrm{o}}$, \\ C. Freissinet ${ }^{\mathrm{e}, \mathrm{p}}$, R. Gellert ${ }^{\mathrm{e}, \mathrm{q}}$, P.R. Mahaffy ${ }^{\mathrm{d}, \mathrm{e}}$, H.E. Newsom ${ }^{\mathrm{e}, \mathrm{r}}$, J.R. Johnson ${ }^{\mathrm{e}, \mathrm{s}}$, L.C. Kah ${ }^{\mathrm{e}, \mathrm{o}}$, \\ K.L. Siebach ${ }^{\mathrm{e}, \mathrm{t}}$, J. Schieber, ${ }^{\mathrm{e}, \mathrm{u}}$, V.Z. Sun ${ }^{\mathrm{e}, \mathrm{h}}$, A.R. Vasavada ${ }^{\mathrm{e}, \mathrm{h}}$, D. Wellington ${ }^{\mathrm{e}, \mathrm{v}}$, R.C. Wiens ${ }^{\mathrm{e}, \mathrm{w}}$, the \\ MSL Science Team
}

${ }^{a}$ NASA Johnson Space Center, Houston, TX, USA

${ }^{\mathrm{b}}$ NASA Ames Research Center, Moffett Field, CA, USA

${ }^{\mathrm{c}}$ Planetary Science Institute, Tucson, AZ, USA

${ }^{\mathrm{d}}$ NASA Goddard Space Flight Center, Greenbelt, MD, USA

${ }^{\text {e }}$ Chesapeake Energy, Oklahoma City, OK, USA

${ }^{\mathrm{f}}$ Geophysical Laboratory, Carnegie Institution for Science, Washington, DC, USA

${ }^{\mathrm{g}}$ Jacobs Technology at NASA Johnson Space Center, Houston, TX, USA

${ }^{\mathrm{h}}$ Jet Propulsion Laboratory, California Institute of Technology, Pasadena, CA, USA

${ }^{i}$ The Lunar and Planetary Institute, Houston, TX, USA

${ }^{\mathrm{j}}$ University of Arizona, Tucson, AZ, USA

${ }^{\mathrm{k}}$ California Institute of Technology, Pasadena, CA, USA

${ }^{1}$ SETI Institute, Mountain View, CA, USA

${ }^{\mathrm{m}}$ University of Leicester, Leicester, LE1 7RH, UK

${ }^{\mathrm{n}}$ USGS Astrogeology Science Center, Flagstaff, AZ USA

${ }^{\circ}$ University of Tennessee, Knoxville, TN, USA

${ }^{\mathrm{p}}$ Laboratoire Atmosphères, Milieux, Observations Spatiales, Guyancourt, France

${ }^{\mathrm{q}}$ University of Guelph, Ontario, Canada

${ }^{\mathrm{r}}$ University of New Mexico, Albuquerque, NM, USA

${ }^{\mathrm{S}}$ Johns Hopkins University Applied Physics Laboratory, MD, USA

${ }^{\mathrm{t}}$ Rice University, Houston, TX, USA

${ }^{\mathrm{u}}$ University of Indiana, Bloomington, IN, USA

${ }^{v}$ Arizona State University, Tempe, AZ, USA

${ }^{\mathrm{w}}$ Los Alamos National Laboratory, Los Alamos, NM, USA

\section{A R T I C L E I N F O}

Handling Editor: Carita Augustsson

Keywords:

Mars

Mineralogy

CheMin

Mars Science Laboratory

\begin{abstract}
A B S T R A C T
The Mars Science Laboratory Curiosity rover arrived at Mars in August 2012 with a primary goal of characterizing the habitability of ancient and modern environments. Curiosity was sent to Gale crater to study a sequence of $\sim 3.5 \mathrm{Ga}$ old sedimentary rocks that, based on orbital visible and near- to short-wave infrared reflectance spectra, contain secondary minerals that suggest deposition and/or alteration in liquid water. The sedimentary sequence in the lower slopes of Mount Sharp in Gale crater preserves a dramatic shift on early Mars from a relatively warm and wet climate to a cold and dry climate, based on a transition from smectite-bearing strata to sulfate-bearing strata. The rover is equipped with instruments to examine the sedimentology and identify compositional changes in the stratigraphy. The Chemistry and Mineralogy (CheMin) instrument is one of two internal laboratories on Curiosity and includes a transmission X-ray diffractometer (XRD) and X-ray fluorescence (XRF) spectrometer. CheMin measures loose sediment samples scooped from the surface and drilled rock powders, and the XRD provides quantitative mineralogy to a detection limit of $\sim 1 \mathrm{wt} \%$ for crystalline phases.
\end{abstract}

\footnotetext{
* Corresponding author.

E-mail address: elizabeth.b.rampe@nasa.gov (E.B. Rampe).
} 
Curiosity has traversed $>20 \mathrm{~km}$ since landing and has primarily been exploring an ancient lake environment fed by streams and groundwater. Of the 19 drilled rock samples analyzed by CheMin as of sol 2300 (January 2019), 15 are from fluvio-lacustrine deposits that comprise the Bradbury and Murray formations. Most of these samples were drilled from units that did not have a clear mineralogical signature from orbit. Results from CheMin demonstrate an astounding diversity in the mineralogy of these rocks that signifies geochemical variations in source rocks, transportation mechanisms, and depositional and diagenetic fluids. Most detrital igneous minerals are basaltic, but the discovery in a few samples of abundant silicate minerals that usually crystallize from evolved magmas on Earth remains enigmatic. Trioctahedral smectite and magnetite at the base of the section may have formed from low-salinity pore waters with a circumneutral $\mathrm{pH}$ in lake sediments. A transition to dioctahedral smectite, hematite, and Ca-sulfate going up section suggests a change to more saline and oxidative aqueous conditions in the lake waters themselves and/or in diagenetic fluids. Perhaps one of the biggest mysteries revealed by CheMin is the high abundance of X-ray amorphous materials (15-73 wt.\%) in all samples drilled or scooped to date. CheMin has analyzed three modern eolian sands, which have helped constrain sediment transport and mineral segregation across the active Bagnold Dune Field. Ancient eolian sandstones drilled from the Stimson formation differ from modern eolian sands in that they contain abundant magnetite but no olivine, suggesting that diagenetic processes led to the alteration of olivine to release Fe(II) and precipitate magnetite. Fracture-associated halos in the Stimson and the Murray formations are evidence for complex aqueous processes long after the streams and lakes vanished from Gale crater. The sedimentology and composition of the rocks analyzed by Curiosity demonstrate that habitable environments persisted intermittently on the surface or in the subsurface of Gale crater for perhaps more than a billion years.

\section{Gale crater and the mission goals of the Mars Science Laboratory}

The Mars Science Laboratory (MSL) rover Curiosity landed in Aeolis Palus on the northwestern plains of Gale crater, Mars in August 2012 and has been actively exploring its surface for more than six Earth years. Gale crater is an impact basin $\sim 155 \mathrm{~km}$ in diameter that formed $\sim 3.8 \mathrm{Ga}$ before present during the late Noachian epoch (Thomson et al., 2011) near the Mars equator, on the dichotomy boundary between the southern cratered highlands and northern lowlands (Fig. 1A). The floor of Gale crater is $4.5 \mathrm{~km}$ below the Mars datum (Mars average elevation), and Gale existed as a deep depression in the Mars crust (Fig. 1B) at a time when planet-wide morphological evidence suggests that water flowed on its surface (e.g., Craddock and Maxwell, 1993; Howard et al., 2005; Irwin et al., 2005). Therefore, prior to landing it was recognized that there was a high likelihood that water was present in the crater during an early "wet and warm" (at least relatively speaking) period of Mars' geologic history, at a time when evidence of the first oceans and signs of early life are found on Earth.

The science goals of the Mars Science Laboratory mission are to: 1) assess Mars' biological potential, 2) characterize the geology of the landing region, 3) explore the past habitability of Mars, and 4) characterize the broad spectrum of surface radiation (Grotzinger et al., 2012). Since landing over six Earth years ago, the MSL Science Team has addressed each of the above goals while investigating processes that were active over much of Mars' history, from the formation of the crust to modern eolian and atmospheric processes.

The principal goal of the MSL mission is to find evidence of "habitability" on Mars. In understanding terrestrial habitability and how life originated and radiated on the early Earth, Mars serves as a valuable surrogate; nearly all of Earth's rocks of this age have been subducted and destroyed as a result of plate tectonics and the remaining rocks from early Earth have been heated to metamorphic temperatures such that the original compositions have been altered (e.g., Fedo, 2000; Mloszewska et al., 2012). Mars never experienced extensive plate tectonics (e.g., Breuer and Spohn, 2003), and there is little evidence that its surface sediments have ever been deeply buried or extensively heated. The opportunity exists on Mars, and especially in Gale crater, therefore, to characterize these ancient sediments that are in much the same condition today as they were when deposited, elucidating the habitability potential of their depositional environments and perhaps even identifying evidence of early life.

Gale is among a class of craters that, after they were formed, were partially or fully filled with sediment, and over eons of time eroded, exposing original features and any remaining sediments. Recent gravimetric analyses using Curiosity's accelerometers, however, suggest the crater was never completely filled with sediment (Lewis et al., 2019). A key distinguishing feature of Gale is the presence of a $\sim 5 \mathrm{~km}$ high central mound of layered sedimentary rock named Aeolis Mons (informally known as Mount Sharp, named for the American geomorphologist Dr. Robert Sharp; Fig. 1B). Visible and near- to short-wave infrared reflectance spectra collected from orbit reveal that the lowermost slopes of Mount Sharp contain a variety of minerals that are indicative of water-rock interactions, and that these mineral assemblages change as a function of stratigraphic position in a succession of flatlying, laterally extensive units (Fig. 1C; Milliken et al., 2010; Fraeman et al., 2013, 2016). Phyllosilicate (i.e., layered silicate minerals composed of stacked sheets of silica tetrahedra and Mg-, Fe(II,III)-, and Al-O $(\mathrm{OH})$ octahedra, including the groups smectite, vermiculite, illite, kaolinite, serpentine, micas, and chlorite, commonly called clay minerals) spectral signatures are observed in some stratigraphic units near the base of Mount Sharp, and sulfate-bearing minerals become more prevalent in younger, stratigraphically higher sedimentary units (Milliken et al., 2010). This mineralogical transition suggests that the conditions under which the sediments were deposited changed through time. The broad mineral stratigraphy with sulfate-bearing units overlying phyllosilicate-bearing units has been recognized in similarly aged deposits planet-wide (e.g., Wiseman et al., 2010; Grotzinger and Milliken, 2012), and this mineralogical succession may mark the beginning of the transition from a relatively wet and warm early Mars to a very dry and cold modern Mars (e.g., Bibring et al., 2006; Milliken et al., 2010). The lowest visible units of Mount Sharp are $\sim 3.6-3.8 \mathrm{Ga}$ old, based on crater counting ages and superposition relationships (Thomson et al., 2011). The presence of minerals in these strata that either form in water or as a consequence of aqueous alteration suggests that they preserve evidence of ancient aqueous environments. In addition to phyllosilicate and sulfate mineral spectral signatures, the lower slope of Mount Sharp displays a prominent, local ridge (informally known as Vera Rubin ridge, named for the American astronomer) characterized by strong orbital spectral signatures of the Fe(III) oxide mineral hematite (Fraeman et al., 2013, 2016). The upper portion of Mount Sharp is comprised of dust-mantled cross-bedded units that unconformably overlie portions of sulfate-bearing materials and are likely eolian deposits (e.g., Anderson and Bell, 2010).

The main goal of this paper is to provide an overview of MSL's major mineralogical and geochemical discoveries with a focus on the mineralogical results from the Chemistry and Mineralogy (CheMin) instrument. We start by describing the capabilities of Curiosity's science 

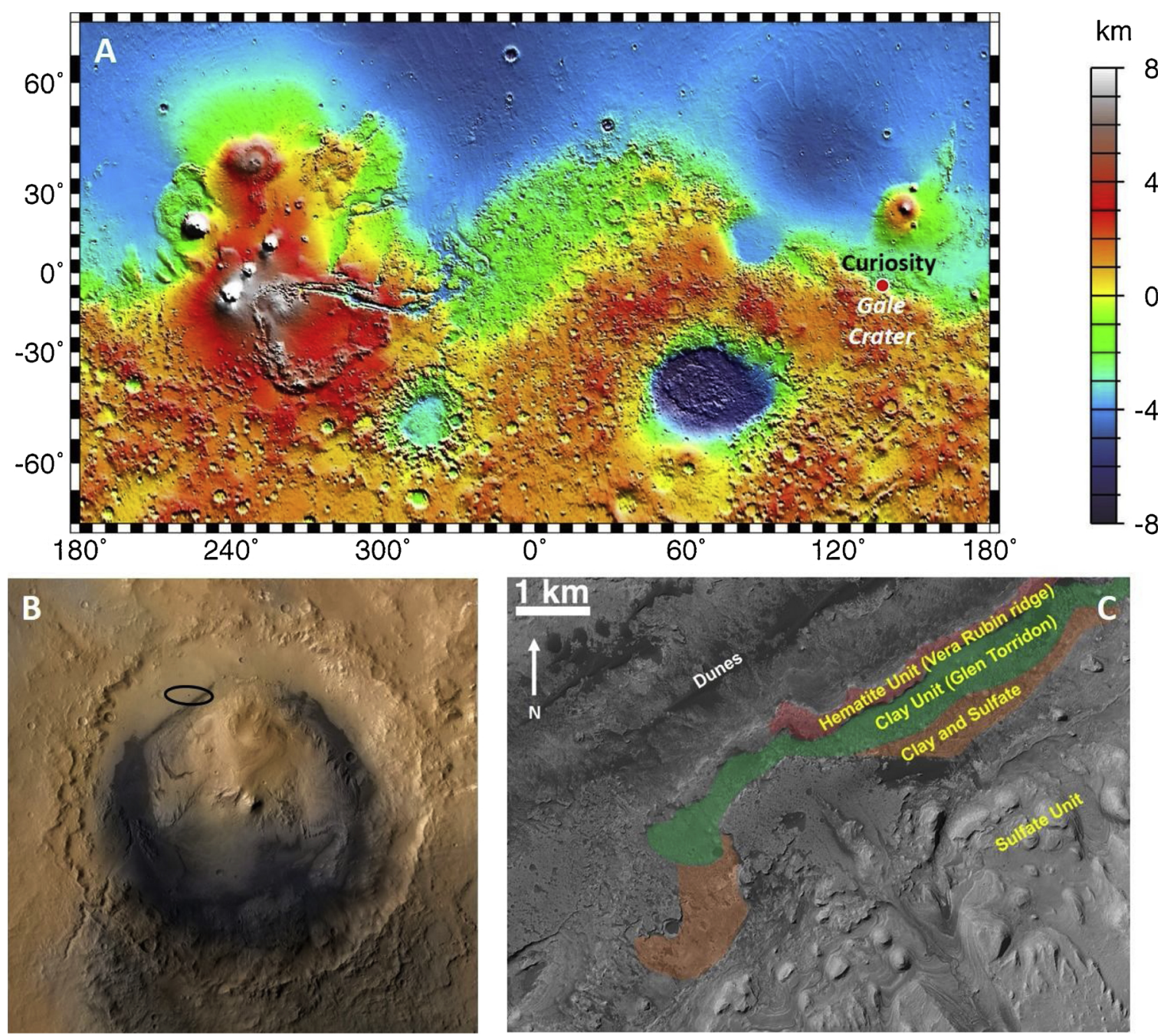

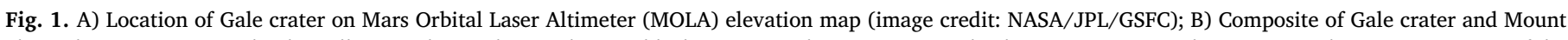

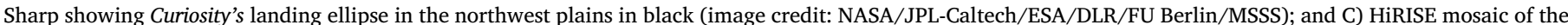

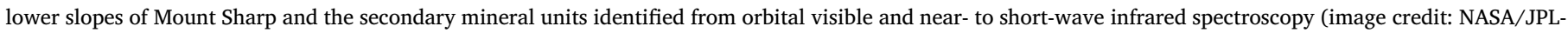
Caltech/MSSS/JHUAPL/Brown University).

payload and methods utilized to perform the mineralogical and geochemical investigations. We then summarize the geologic and geomorphologic units and materials encountered by Curiosity during its traverse. This introduction sets the stage for a more in-depth description of the mineralogy of samples, organized according to their age and depositional environment. These mineralogic details, in concert with geologic context and geochemical measurements, provide insights into the diversity of igneous materials on Mars, modern eolian processes, and the nature of ancient aqueous conditions in Gale crater, leading to the identification of ancient habitable martian environments. Finally, we discuss MSL's most recent investigation of Vera Rubin ridge and look ahead to what the rover may encounter as it climbs Mount Sharp.

\section{Curiosity's science payload}

Curiosity carries a suite of scientific instruments to characterize surface and near-surface rocks and sediments (Fig. 2). The elemental composition of rocks and loose sediments is measured remotely $(\sim 1-7$ $\mathrm{m}$ distance) using the ChemCam Laser Induced Breakdown Spectroscopy instrument (LIBS; Maurice et al., 2012, 2016; Wiens et al., 2012, 2015a, 2015b). After more than two years of nominal operations on Mars, ChemCam lost autofocus functionality for LIBS and Remote Micro-Imager (RMI) operation on sol 801. The instrument team redesigned the flight software to regain full operational capacity and improve the instrument's ability to focus on infinity, which allowed for long-distance RMI mosaics of the upper parts of Mount Sharp and other distant localities (Le Mouélic et al., 2015; Peret et al., 2016). ChemCam can also passively measure spectra in the visible and near-infrared wavelength range. These spectra are useful in identifying Fe-bearing minerals present in rocks and loose sediments (Johnson et al., 2015, 2016, 2017a) and they complement the multispectral imaging capability of Mastcam (Bell et al., 2017; Wellington et al., 2017a). ChemCam has the ability to select autonomously targets using the Autonomous Exploration for Gathering Increased Science (AEGIS) system (Francis et al., 2017). AEGIS selects geological targets in images from the rover's navigation cameras and measures them with ChemCam without input from ChemCam scientists and engineers on Earth. The system has markedly increased the pace of data collection with ChemCam since its implementation in May 2016, in particular improving the statistics on baseline bedrock compositions along the rover traverse.

The Alpha Particle X-ray Spectrometer (APXS), located on the arm of the rover, provides quantitative elemental data from $\sim 2 \mathrm{~cm}$ diameter areas of target rocks and soils (i.e., loose, unconsolidated surface materials) through the detection of characteristic X-rays emitted by incident alpha particles and X-rays from ${ }^{244} \mathrm{Cm}$ sources (i.e., using 


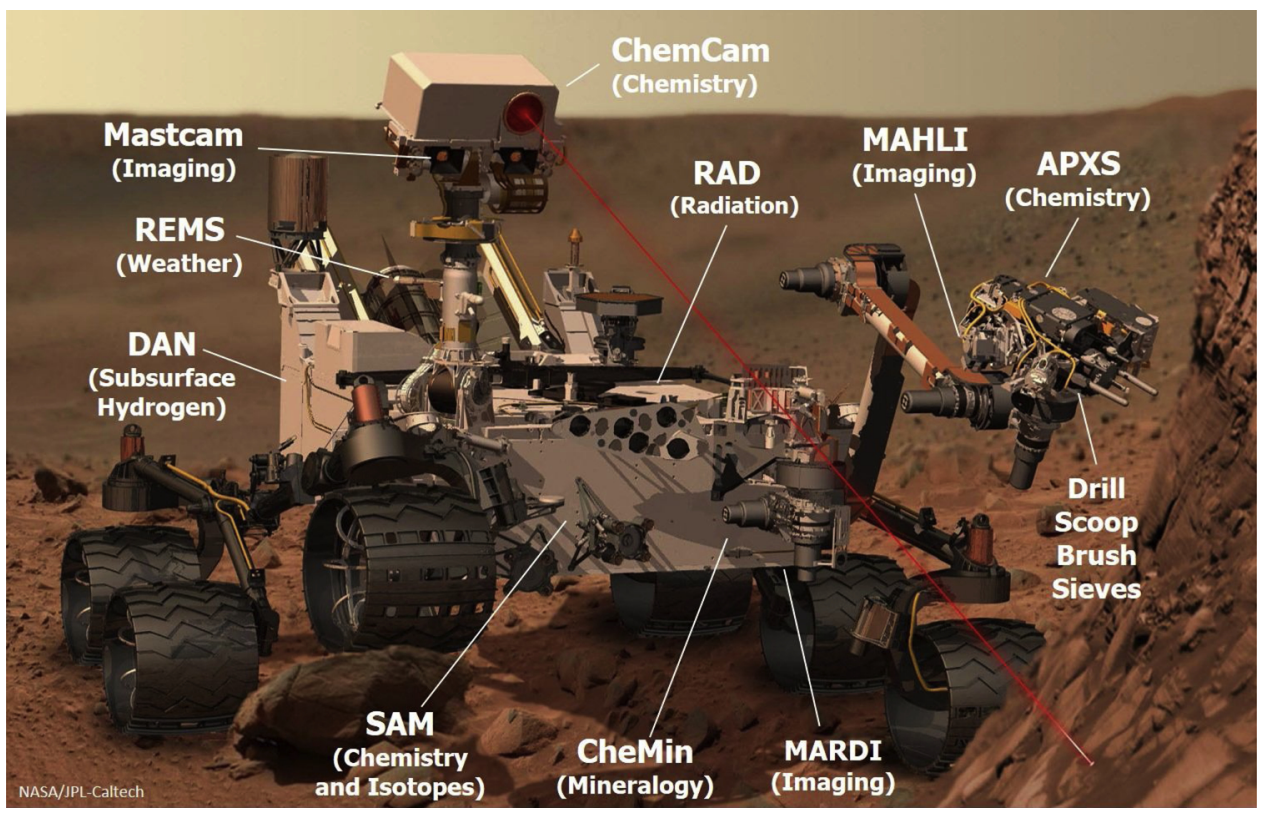

Fig. 2. Schematic of the Curiosity rover showing the location of the different science instruments. Image credit: NASA/JPL-Caltech.

particle induced X-ray emission spectroscopy and X-ray fluorescence spectroscopy; Gellert et al., 2006; Campbell et al., 2012). Minerals and $\mathrm{X}$-ray amorphous materials in scooped soil or drilled rock samples are identified and quantified by the CheMin instrument using X-ray diffraction (Blake et al., 2012). Evolved gas analyses from the Sample Analysis at Mars (SAM) instrument of these same samples can inform mineralogy as well as detect and identify organic molecules (Mahaffy et al., 2012). Geomorphological, structural, and sedimentological features are assessed with images of landscapes, outcrops, and rock and sediment textures obtained by the science cameras on the rover: Mastcam (Malin et al., 2017), the Mars Hand Lens Imager (MAHLI, Edgett et al., 2012), the Mars Descent Imager (MARDI, Malin et al., 2017), and the RMI on ChemCam (Maurice et al., 2012). Instruments that interrogate the modern environment include the Dynamic Albedo of Neutrons (DAN) instrument, which uses neutron spectrometry to quantify $\mathrm{H}$ abundances in the upper $\sim 1 \mathrm{~m}$ of the surface as a proxy for water or hydrated minerals (Litvak et al., 2008); the Rover Environmental Monitoring Station (REMS), which measures wind speed/direction, pressure, relative humidity, air and ground temperatures, and ultraviolet radiation (Gómez-Elvira et al., 2012); and the background solar and cosmic radiation detector (RAD; Hassler et al., 2012), which measures ambient particle and radiation fluxes.

Samples provided to the two laboratory instruments inside the rover (CheMin and SAM) are collected, processed and delivered by the Sample Acquisition, Sample Processing, and Handling (SA/SPaH) and Collection and Handling for In-Situ Martian Rock Analysis (CHIMRA) systems (Anderson et al., 2012). Samples can be obtained in two ways: 1) loose soil samples are scooped from the upper few $\mathrm{cm}$ of the surface and sieved to $<1 \mathrm{~mm}$ and $<150 \mu \mathrm{m}$ grain sizes. Aliquots of the $<150$ $\mu \mathrm{m}$ material are delivered to CheMin and SAM for analysis; SAM can also process the $<1 \mathrm{~mm}$ sieved fraction. 2) Powdered rock samples are obtained with a percussion drill. The drill bit is $\sim 1 \mathrm{~cm}$ in diameter and can penetrate to a depth of $\sim 6 \mathrm{~cm}$. For most of the mission to date, the powdered material that reached SA/SPaH and CHIMRA traveled up the drill stem and was sourced from the lower $\sim 4 \mathrm{~cm}$ of drilled material. The samples were sieved, and aliquots were portioned and then delivered to the two laboratory instruments inside the rover.

An anomaly in the drill feed mechanism occurred on sol 1536 that precluded its use. As a result, beginning with the sample "Duluth," rocks were drilled by a new method called "feed-extended drilling," in which the drill remains extended to its full length and is pressed into the surface by Curiosity's arm (essentially used like a hand drill). With feed-extended drilling, the sample can no longer pass through CHIMRA to be sieved and portioned. Drilled rock samples are now delivered to CheMin and SAM by hovering the drill bit over the instruments' inlets and reversing the drill rotation to allow sample material to exit the drill bit and drop into the inlets. Engineers at the Jet Propulsion Laboratory (JPL) used the testbed arm and drill to constrain drill and delivery parameters so that CheMin and SAM receive sample volumes similar to those delivered during prior drill operations. The grain size of the powder produced by the drill is typically $<<150 \mu \mathrm{m}$ (Anderson et al., 2012), and any large fragments that could potentially clog the CheMin inlet are kept from entering the instrument by a $1 \mathrm{~mm}$ screen in the funnel. Whether scooped or drilled, once the analyses are completed, the remaining material in the drill stem or CHIMRA is dumped onto the martian surface and the APXS instrument is used to obtain a quantitative elemental analysis of the bulk sample and any sieved size fractions. Dump piles are typically $>2 \mathrm{~cm}$ in diameter and the alignment of the centers of MAHLI images with the APXS field of view is precise within a few mm such that the dumped material fills the APXS field of view and the underlying surface does not contribute significantly to the APXSmeasured chemistry (e.g., VanBommel et al., 2016).

Data collected by the instruments aboard Curiosity can be used to characterize the elemental, molecular, isotopic, and mineralogical compositions of samples collected from the upper $\sim 2-6 \mathrm{~cm}$ of the surface, and the abundance of $\mathrm{H}$ in the upper meter of the surface. With this information, the MSL Science Team can infer ancient martian habitability, albeit based on an Earth-centric understanding of the requirements of microbial life (e.g., Hoehler, 2007).

\section{The CheMin instrument and methods for quantifying mineralogy}

Here, we provide a brief overview of the CheMin instrument and the methods used for calibrating the data, identifying mineralogy, quantifying mineral and X-ray amorphous abundances, and calculating crystal chemistry from refined unit-cell parameters. Blake et al. (2012) describe the instrument, its data products, and calibration, and Morrison et al. (2018a, b) discuss the methods for calculating crystal chemistry from unit-cell parameters.

The CheMin X-ray Diffraction (XRD) / X-ray Fluorescence (XRF) instrument produces XRD patterns of scooped soil or drilled rock 
powder. Samples have been either sieved to $<150 \mu \mathrm{m}$ or a comparable powder has been delivered directly; a $\sim 75 \mathrm{~mm}^{3}$ aliquot of material (this volume was more tightly constrained when the drill and CHIMRA operated nominally) is delivered to the CheMin funnel, accessed through a port on the rover deck. Sieved soils and drill powders are delivered through CheMin's inlet funnel to one of the instrument's 27 reusable sample cells. Sample cells are arrayed in pairs on the perimeter of a sample wheel (Fig. 3). The cells are designed to be used more than once. Individual cells are filled and analyzed at the top of the wheel, then rotated $180^{\circ}$ and emptied into a sump at the bottom of the instrument. Each dual-cell sample holder is shaped like a tuning fork, with a sample cell attached to each arm. The cells hold the sample in a 7 mm diameter, $170 \mu \mathrm{m}$ thick volume between two $\sim 7 \mu \mathrm{m}$-thick polymer (Mylar or Kapton) windows. A piezoelectric actuator drives the sample holder at its natural resonance and the resulting vibration causes a convective flow of sample material, randomizing grain orientations and minimizing preferred orientation effects. The instrument utilizes a transmission geometry with a microfocus Co X-ray source collimated to a $70 \mu \mathrm{m}$ diameter X-ray beam that passes through the center of the sample cell (Fig. 4). An X-ray energy-sensitive charge-coupled device (CCD) collects two-dimensional (2D) XRD images over 3-38 hours of analysis. The CCD has a $600 \times 582$ pixel data collection area, where pixels are $40 \times 40 \mu \mathrm{m}$, creating an angular resolution of $\sim 0.35^{\circ} 2 \theta$. This angular resolution allows the refinement of plagioclase and olivine unit-cell parameters such that An and Fo values are constrained to a $1 \sigma$ error of $\sim 2-10$ (Morrison et al., 2018b). On average, samples are measured for a total of $22.5 \mathrm{~h}$ over three separate nights. The CCD detector is operated in single-photon counting mode and can be used to measure the amount of charge generated by each photon (and hence its energy). Diffracted CoK $\alpha$ X-ray photons (i.e., $\lambda=1.79027 \AA$ ) are identified by their energy and are summed circumferentially to yield a 2D energy-discriminated CoKa diffraction pattern (Fig. 4). All detected photons are summed into a histogram that represents an XRF spectrum of the sample. Parts of the XRF system were descoped prior to launch such that the XRF data are qualitative, so quantitative compositional data from APXS and/or ChemCam are used to complement mineralogical data from CheMin. The 2D XRD images are converted to 1D diffraction patterns (Fig. 5) for analysis using a modification of the GSE_ADA software (Dera et al., 2013). Initial calibration of the pattern is made with reference to beryl-quartz standards contained in two of five sealed standards on the CheMin sample wheel.

CheMin's mineral detection limit is as low as $\sim 1 \mathrm{wt} . \%$, depending on the crystallinity of the phase and the presence or absence of overlapping peaks (Castle and Treiman, 2019). Quantitative mineral abundances and unit-cell parameters of the major phases (e.g. $>\sim 5$ wt.\%) are determined through Rietveld refinement of 1-dimensional XRD patterns. The Rietveld refinement technique (e.g., Rietveld, 1969; Bish and Howard, 1988; Post and Bish, 1989) is used to fit the peak positions, intensities, and breadths by adjusting the scale factors, unitcell parameters, and full-width half-maxima of peaks generated from crystallographic information files (CIFs). The CheMin team commonly uses the Jade ${ }^{\mathrm{TM}}$ software by Materials Data Inc. to perform these refinements. Mathematical relationships between unit-cell parameters and crystal chemistry are used to determine compositions of major phases (feldspar, pyroxene, olivine, spinel, and jarosite) in each sample (Morrison et al., 2018a). Tolerance variations in the machining of the sample cell assemblies cause individual cells to be offset from their ideal diffraction position by -25 to $-113 \mu \mathrm{m}$ relative to an ideal sample cell-to-CCD distance of $18.5302 \mathrm{~mm}$. To correct for this positioning offset and the resulting shift in 2-theta peak positions, an internal calibration method was developed that is based on the refined cell parameters of plagioclase feldspar, present as a major phase in all but one of the samples measured by CheMin (Morrison et al., 2018b).

Abundances of X-ray amorphous, poorly crystalline, and paracrystalline materials (e.g., volcanic glasses, opaline silica, smectite) are estimated using a modified version of the full pattern fitting program
FULLPAT (Chipera and Bish, 2002, 2013). FULLPAT uses a leastsquares minimization to optimize the fit between measured CheMin patterns and patterns of individual minerals and X-ray amorphous phases measured on CheMin test-bed instruments. X-ray amorphous materials and phyllosilicates in the FULLPAT library include basaltic and rhyolitic glasses, opal-A, allophane, Fe-allophane, ferrihydrite, illite, saponite, montmorillonite, and nontronite.

The composition of X-ray amorphous materials is estimated from mass balance calculations using mineral abundances and the crystal chemistry of major phases calculated from unit-cell parameters derived from Rietveld refinements, the estimated abundance of X-ray amorphous materials from FULLPAT, and the bulk chemical composition measured by APXS of the drill fines that best represent the sample measured by CheMin (e.g., Blake et al., 2013; Morris et al., 2013; Dehouck et al., 2014; Morrison et al., 2018b). When the drill was operating nominally, APXS data of fines sieved to $<150 \mu \mathrm{m}$ were used in the calculations. In the current drill configuration, APXS data of the bulk sample dumped from the drill stem are used. Subtracting the calculated composition of all crystalline phases from the APXS bulk composition yields the composition of the X-ray amorphous component. If the abundance of the amorphous component is underestimated by FULLPAT, its calculated composition may yield negative values for some elemental oxides, which is geochemically impossible. In such cases, the amorphous abundance determined by FULLPAT is increased until the values for all elemental oxides are zero or positive. Note that minor and trace elements in minerals and elements that are present in crystalline phases below CheMin's detection limit $(\sim 1 \mathrm{wt} . \%)$ are incorporated into the calculated amorphous composition, but may not actually reside in that component of the sample. As a result, some elemental oxides, including $\mathrm{TiO}_{2}, \mathrm{Cr}_{2} \mathrm{O}_{3}, \mathrm{MnO}$, and $\mathrm{P}_{2} \mathrm{O}_{5}$, may be unrealistically concentrated in the amorphous component.

The experimental data records (EDRs, i.e., the raw data) and reduced data records (RDRs, i.e., the processed data) for CheMin diffraction and fluorescence data are available on the Planetary Data System. Data and results for individual samples and sample descriptions

CheMin sample wheel - view of the side facing the $X$-ray source

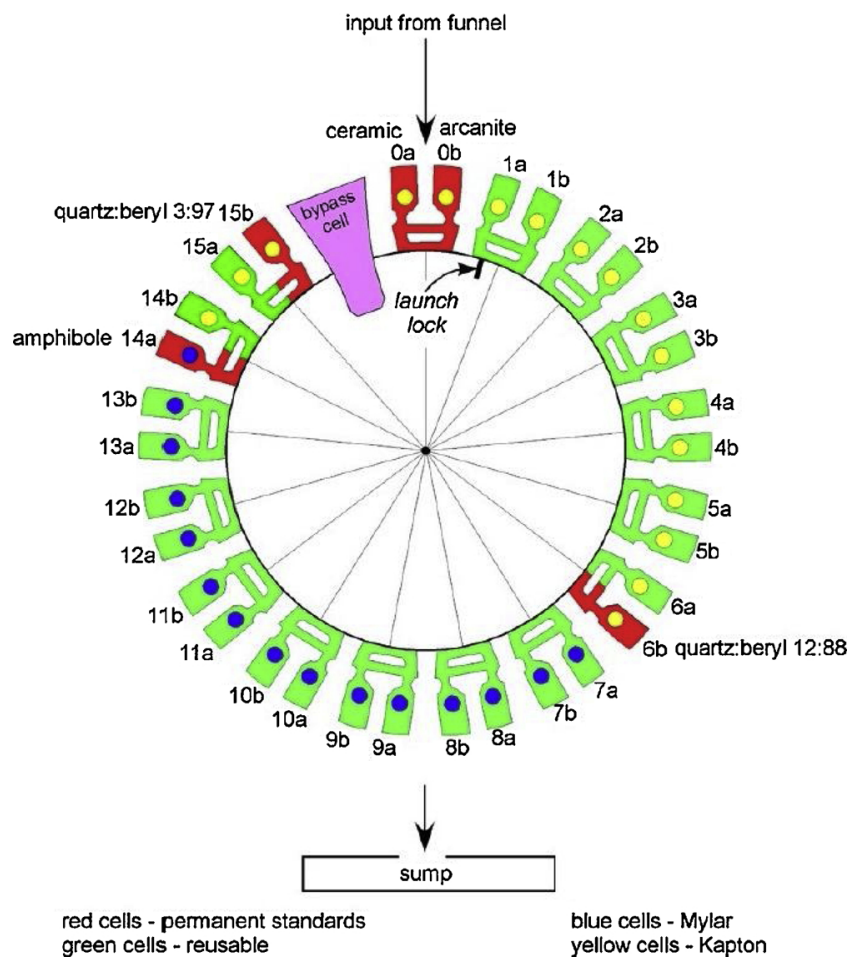

Fig. 3. Configuration of sample cells in CheMin. From Blake et al. (2012). 


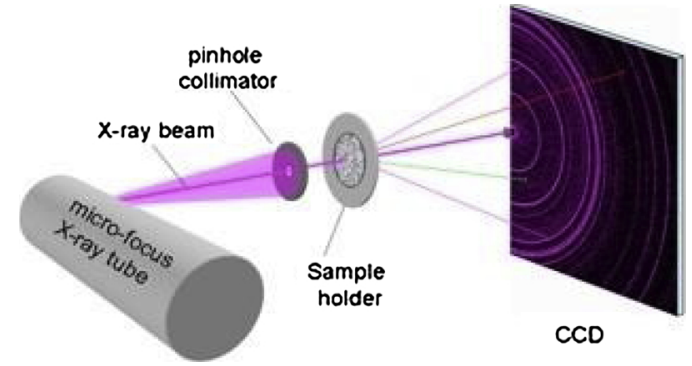

Fig. 4. Illustration of the basic components of the CheMin instrument and the path of the X-rays. From Blake et al. (2012).

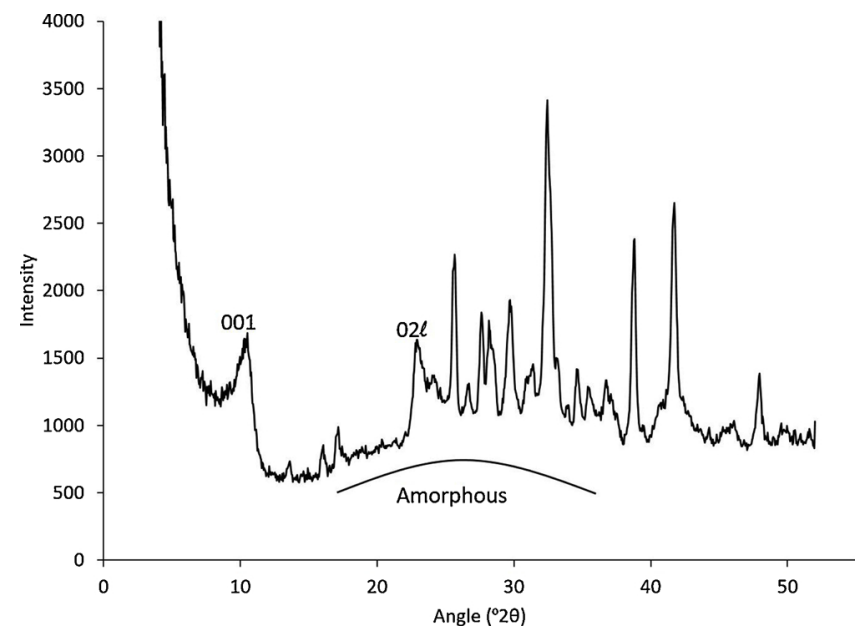

Fig. 5. CheMin 1D XRD pattern of the "Marimba" (MB) sample from the Karasburg member of the Murray formation on Mount Sharp. "Marimba" contains the highest proportion of phyllosilicate of any sample drilled to date (28 wt.\%). The (001) and (02l) phyllosilicate peaks are labeled. The X-ray amorphous background is outlined in black.

are also compiled on an Open Data Repository (https://odr.io/CheMin), as are companion data from APXS and open-access downloadable pdfs of all publications authored by the CheMin team.

\section{An overview of Curiosity's traverse in Gale crater}

Curiosity's tenure on Mars is measured in "sols" or martian days (a sol is roughly 39 min longer than an Earth day, and a martian sidereal year is $\sim 668$ sols or slightly less than two Earth years in length). As of sol 2300, Curiosity has driven over $20 \mathrm{~km}$ laterally and gained $\sim 400 \mathrm{~m}$ of elevation (Fig. 6). Because the sediments composing Mount Sharp are roughly flat lying, this corresponds to $\sim 400 \mathrm{~m}$ of stratigraphic section (Fig. 7). Geologic materials encountered by Curiosity during its traverse are almost exclusively sedimentary, and the geochemical compositions of the sedimentary units are largely consistent with low-temperature (e.g., depositional, authigenic, and diagenetic) alteration of rock and mineral fragments derived from a basaltic protolith (McLennan et al., 2014; Siebach et al., 2017; Bedford et al., 2019). However, many examples of float (rocks transported away from their original source region) having primary igneous textures have been identified (Sautter et al., 2014; Cousin et al., 2017a) and their compositions from APXS and ChemCam suggest magmatic diversity in and around Gale crater (Stolper et al., 2013; Sautter et al., 2014, 2015; Cousin et al., 2017a). Some of this float is present as pebbles in the conglomerate facies in the Bradbury group (Williams et al., 2013; Mangold et al., 2016; Fig. 8A shows the Hottah conglomerate where Curiosity landed, exposed by the sky crane's landing rockets). The northwest crater rim shows incision from fluvial processes, indicating the nearby crater rim was a likely source of the pebbles (Williams et al., 2013). Some of the igneous float was probably directly emplaced onto the Gale surface as impact ejecta (Yingst et al., 2013).

Many of the igneous samples are notably feldspar-rich, mainly extrusive trachybasalts/trachyandesites, with some feldspathic cumulates where feldspar phenocrysts (primarily plagioclase) compose up to $80 \%$ of the rock. These igneous rocks are thought to have resulted from low pressure fractional crystallization of basaltic melt of the Adirondack Class (from the Mars Exploration Rovers) (Edwards et al., 2017). The similarity of the basaltic end member to much of the Gale sediment bulk compositions suggests that this type of Fe-rich olivine tholeiite is the dominant constituent of the Bradbury group (Edwards et al., 2017; Bedford et al., 2019). However, intriguingly, potassium and sanidinerich sedimentary units in the Bradbury group (Anderson et al., 2015; Le Deit et al., 2016; Mangold et al., 2016; Treiman et al., 2016) and possible alkaline igneous float (Stolper et al., 2013) show that alkaline igneous rocks were also a significant part of the Gale catchment (Siebach et al., 2017; Bedford et al., 2019) and were present over a larger portion of the southern highlands (Sautter et al., 2015).

The physical sedimentology of the portion of Gale crater traversed by Curiosity has been carefully documented by the MSL Sedimentology / Stratigraphy working group, who pored over thousands of images and observations to assemble the stratigraphic column shown in Fig. 7. This figure does not represent a vertical section, but is more akin to a log of the lithologies encountered along the traverse. The mineralogical and geochemical data obtained by Curiosity should be viewed and interpreted in the context of this stratigraphic record.

On the plains of Gale crater (i.e., Aeolis Palus), before climbing the slopes of lower Mount Sharp, Curiosity investigated primarily fluvial and deltaic deposits (Fig. 8) that compose the Bradbury group (e.g., Grotzinger et al., 2015). The observation of coarse-grained sedimentary deposits, including conglomerate, grain-supported sandstone, and pebbly sandstone with common cross-stratification is consistent with deposition in a fluvial environment (e.g., Williams et al., 2013; Vasavada et al., 2014; Grotzinger et al., 2015; Edgar et al., 2018a). The cobble-sized clasts in the conglomerate identified near the landing site (Fig. 8A) suggest that the ancient rivers that transported these sediments were up to $0.9 \mathrm{~m}$ deep with an average velocity of $0.20-0.75 \mathrm{~m} / \mathrm{s}$ (Williams et al., 2013).

The lower slopes of Mount Sharp, located southwest of the landing site, were the ultimate goal for Curiosity. Gale crater is what is termed a "go-to" site in the planetary science community, meaning that the principal science target of the MSL mission was actually outside its $6 \times$ $20 \mathrm{~km}$ landing ellipse. However, it was apparent upon landing that a region of high scientific interest where there was a contact between three geomorphological terrain types was nearby. Therefore, from the landing site Curiosity drove east to investigate the Yellowknife Bay formation prior to driving southwest toward the lower slopes of Mount Sharp. At Yellowknife Bay, Curiosity investigated both sandstone and mudstone facies (e.g., Grotzinger et al., 2014; Edgar et al., 2018a). The Sheepbed mudstone in the Yellowknife Bay formation (Fig. 8B) is interpreted to represent an ancient lake (Grotzinger et al., 2014) and is located at the lowest elevation (and stratigraphic level) investigated by Curiosity. If we assume that the strata in Gale crater are flat lying and laterally extensive, the Sheepbed mudstone is the oldest deposit that Curiosity investigated. Two samples were drilled from the Sheepbed mudstone in Yellowknife Bay, named "John Klein" and "Cumberland." These samples were drilled a few meters apart laterally and $\sim 10 \mathrm{~cm}$ apart vertically, allowing the mission to investigate local-scale mineralogical and geochemical variations in an area with significant evidence for early-stage diagenesis (Grotzinger et al., 2014; Léveillé et al., 2014; Siebach et al., 2014; Stack et al., 2014).

Sandstone beds that dip gently to the south (i.e., toward Mount Sharp) were identified in multiple locations along the $8 \mathrm{~km}$ traverse across Aeolis Palus from Yellowknife Bay and are consistent with ancient fluvio-deltaic deposits (Fig. 8C, Grotzinger et al., 2015). Deltas form when rivers flow into standing bodies of water and deposit 


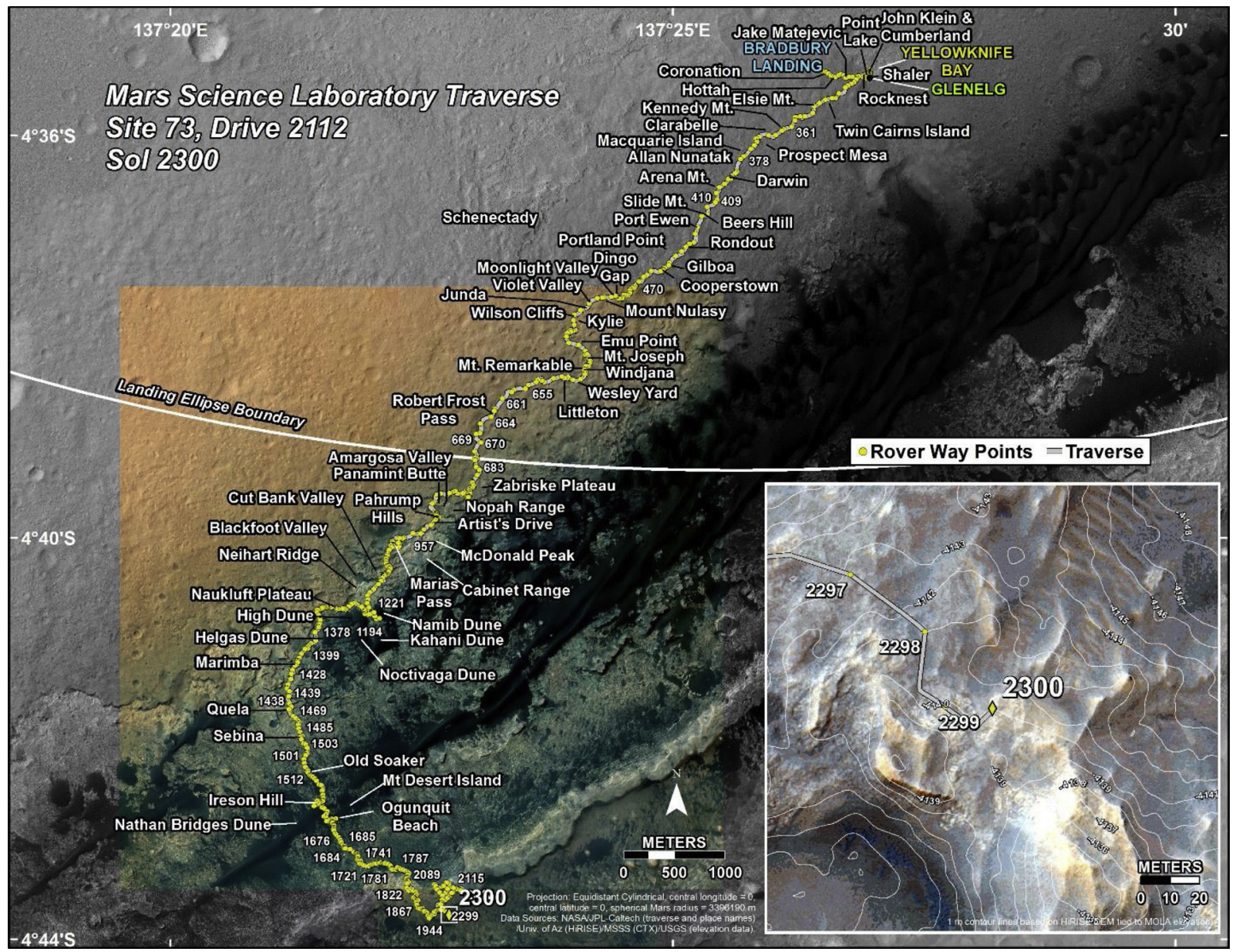

Fig. 6. Curiosity's traverse through Sol 2300 with major waypoints listed. Locations and target names along the traverse are unofficial designations and are selected based on themes for each map quadrant. Each quadrant's theme is a location of geologic interest on Earth. For example, there are locations and target names selected from localities in the Northwest Territories in Canada, the Kimberley province in Australia, Namibia, and Scotland. Image credit: NASA/JPL-Caltech/Univ. of AZ/ MSSS/USGS.

sediment that was transported by the rivers. The dip of distinct clinoforms (i.e., layered deltaic bodies) indicates that the rivers in the region of Curiosity's traverse flowed from north to south, possibly emanating from ice/snow melt in the northern crater rim (Grotzinger et al., 2015). The sample named "Windjana" was drilled from reworked deltaic and eolian sediments in the Kimberley formation (Rice et al., 2017).

Curiosity first reached the units that make up lower Mount Sharp in September 2014. This marked the beginning of the MSL Science Team's investigation of the Murray formation, which has continued up to the present time. The Murray formation has been divided into several distinct stratigraphic members based on minor changes in facies associations (Fig. 7). The outcrops that compose the lowermost portion of the Murray formation (the Pahrump Hills member) are dominated by laminated mudstone with mm-to-cm-scale lamination (Fig. 9A,B). Laminated mudstone is common throughout the Murray formation and is consistent with deposition in lakes (e.g., Fedo et al., 2018; Stack et al., 2018), where thick laminations suggest near-shore deposition in shallow water and thin laminations suggest offshore deposition in deep water (Grotzinger et al., 2015). Sedimentary rock in the Pahrump Hills member exhibits exceptional preservation of original depositional fabrics as well as products of early and late diagenesis. Above the Pahrump Hills member, the Murray formation contains a combination of laminated mudstone, meter-scale trough cross-bedding, ripple cross-laminated sandstone (Fig. 9C), and dm-scale cross-stratified sandstone (Fedo et al., 2018). Cross-stratification suggests deposition in higher-energy environments, and the cross-stratified units observed in the Murray formation are interpreted to have been deposited in both subaqueous (i.e., fluvial) and subaerial (i.e., eolian) environments. Uncommon desiccation cracks (Fig. 9D) suggest drying of sediments and intermittent exposure during lake lowstands (Stein et al., 2018). Isolated observations of NaCl-rich targets (Thomas et al., 2019), rare boron detections (Gasda et al., 2017), and a Mg-sulfate- and Ca-sulfate-rich interval from ChemCam (Rapin et al., 2019) also hint at evaporation. No chloriderich strata have been found, however, suggesting that desiccation was relatively infrequent when these sediments were deposited.

Twelve samples have been drilled from the Murray formation (Table 1, Fig. 7): "Confidence Hills," "Mojave2," "Telegraph Peak," and "Buckskin" from the Pahrump Hills member, "Oudam" from the Hartmann's Valley member, "Marimba" and "Quela" from the Karasburg member, "Sebina" from the Sutton Island member, "Duluth" from the Blunts Point member, "Stoer" from the Pettegrove Point member, and "Highfield" and "Rock Hall" from the Jura member.

The deposits observed in the Bradbury group and in the Murray formation indicate that Gale crater was the site of a long-lived fluviolaucustrine environment at $\sim 3.5$ Ga (Fig. 10; e.g., Grotzinger et al., 2015; Fedo et al., 2018). Rivers and streams originating from the crater rim flowed into lakes on the crater floor. The paucity of mud cracks suggests lake waters were long-lived. Based on sediment deposition rates on Earth, the $400+\mathrm{m}$ of primarily lacustrine stratigraphy that Curiosity has investigated so far represents a few hundreds of thousands to a few millions of years of time (Grotzinger et al., 2015). After deposition, fluids moved through the sediments both before and after they 


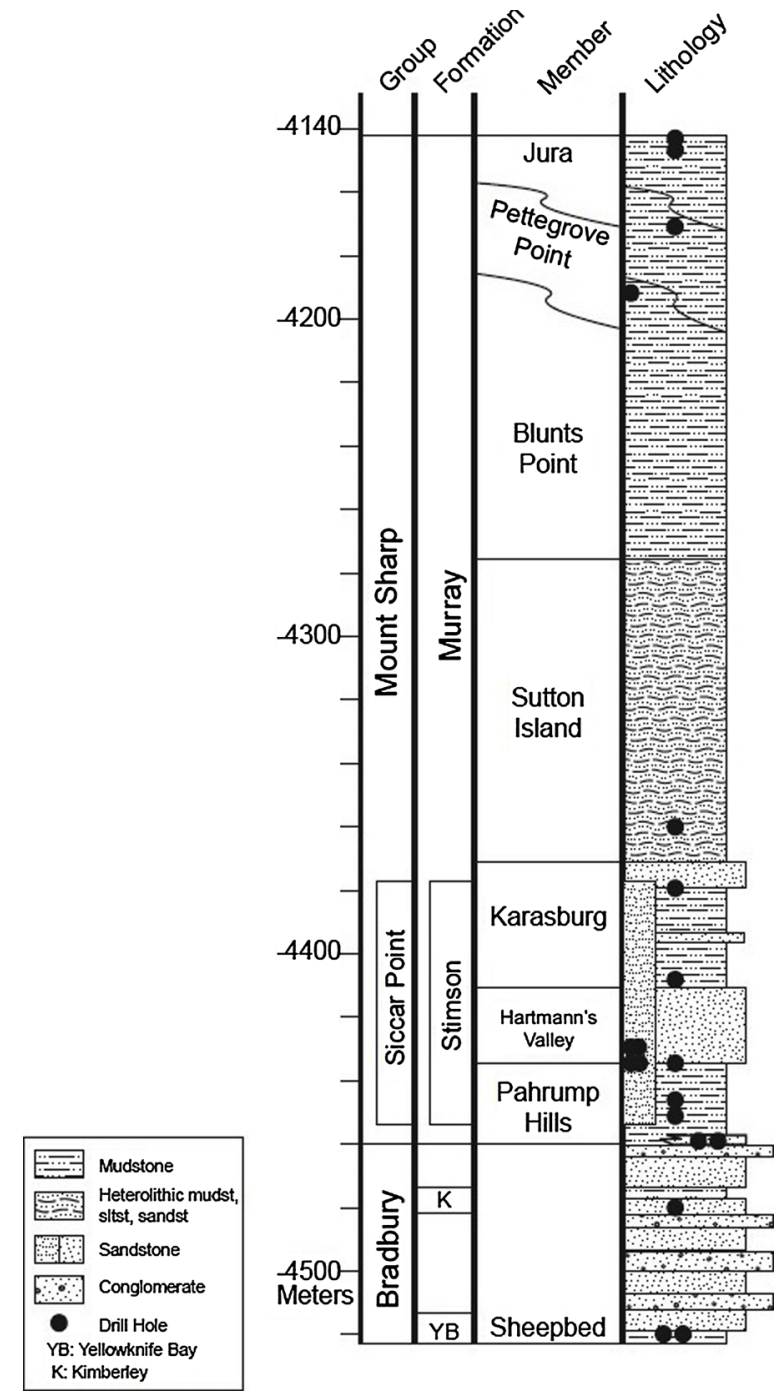

Fig. 7. Stratigraphic column showing the sedimentary units that Curiosity has investigated through January 2019. Note that the Vera Rubin ridge topography does not follow elevation. The western leg of Curiosity's traverse up the Vera Rubin ridge showed lower elevations for the Pettegrove Point and Jura members than the eastern leg of Curiosity's traverse down and back up the Ridge. Credit: Sed/strat group of the MSL Science Team.

were lithified (e.g., Martin et al., 2017), suggesting a prolonged history of aqueous diagenesis in surface and subsurface environments at Gale crater, as will be explored in detail later.

In addition to ancient fluvio-lacustrine deposits, Curiosity has investigated modern and ancient eolian deposits. Curiosity sampled a recently inactive eolian bedform called "Rocknest" (Fig. 11A) close to the landing site (e.g., Blake et al., 2013). Curiosity also executed a twophase sampling campaign in an active eolian basaltic dune field in early 2016 and early 2017 (e.g., Bridges and Ehlmann, 2018; Lapotre and Rampe, 2018). Curiosity's investigation of the Bagnold Dune Field was the first in-situ study of active wind-blown sediments on another planetary surface. Two samples were collected to study sediment transport and sorting across the dune field. The "Gobabeb" sample was collected on sol 1225 from a ripple crest on the Namib Dune, a barchanoidal dune on the northern margin and trailing edge of the dune field (Fig. 11B). The "Ogunquit Beach" sample was collected on sol 1650 from a ripple trough of the Mount Desert Island sand patch near the southern edge of the dune field (Fig. 11C).

The Stimson formation, interpreted as an ancient lithified eolian dune field (Banham et al., 2018), is part of the Mount Sharp group and unconformably overlies the Murray formation (Fig. 12). An unconformity occurs when there is a cessation of sediment deposition, usually with erosion of preexisting sediment prior to continued sediment influx. On Earth, unconformities often occur as a result of tectonic uplift or sea level retreat. Since there is no tectonic uplift in Gale crater and no evidence for lake water breaching the crater rim, this must represent a major change in the climate and depositional regime, including complete drying out of the lake and erosion and removal of a significant portion of the Murray and Bradbury formation sedimentary rocks that had formed in Gale crater. The hiatus in time between the deposition of the Murray and Stimson formations has not been quantified, but it was likely significant because the stratigraphic boundary is abrupt and transitional deposits in relatively wet to relatively dry conditions are not preserved (Banham et al., 2018). Light-toned fracture-associated halos in the Stimson and nearby Murray suggest leaching by late-stage fluids after burial (Frydenvang et al., 2017; Yen et al., 2017; Hausrath et al., 2018). Two of these fracture-associated halos were studied in detail. Samples were drilled from both in the light-toned fracture-associated halos ("Greenhorn" and "Lubango") and in the nearby parent sandstone ("Big Sky" and "Okoruso") to constrain the geochemical processes that formed the halos. Fig. 13 shows an example of a fracture-associated halo observed prior to sampling at a location called Teakettle Junction.

\section{Mineralogy of samples measured by CheMin}

The characterization of the mineralogy and geochemistry of samples from a variety of different depositional environments and time periods provides insight into past and present geologic processes on Mars. All samples measured to date contain igneous minerals, secondary phases, and X-ray amorphous materials. Here we summarize the abundances of minerals and amorphous components, crystal chemistry of major phases from refined unit-cell parameters, and calculated composition of amorphous components from all samples analyzed through sol 2300, the limit of reportable analyses at the time of this writing. Results are grouped according to their depositional environment: Fluvio-lacustrine, ancient eolian, and modern eolian.

\subsection{Fluvio-lacustrine samples}

Most of the rock samples drilled to date were obtained from ancient fluvio-lacustrine deposits (Table 1). Of the 19 rock samples analyzed by CheMin, 13 are mudstones interpreted to be lacustrine deposits and two are fine-grained sandstones interpreted to be reworked fluvial/eolian deposits. The mineralogy of fluvio-lacustrine rocks can tell us about the composition of rocks in the source regions of the sediments, the weathering history of the sediments, and the fluid chemistry of syn- and post-depositional aqueous environments. CheMin has recorded enormous mineralogical variability between fluvio-lacustrine samples that suggests differences in igneous sources, paleoclimatic conditions, and geochemistry of aqueous environments. The mineral abundances of fluvio-lacustrine samples are presented in Table 2, the crystal chemistry of the major minerals in Tables 3 and 4, the abundances of phyllosilicates and X-ray amorphous materials in Table 5, and the calculated composition of the X-ray amorphous materials in Table 6. These results have been reported previously by Vaniman et al. (2014); Treiman et al. (2016); Rampe et al. (2017); Yen et al. (2017); Bristow et al. (2018); Morrison et al. (2018b), Achilles et al. (submitted), and Rampe et al. (2020). Here, we provide an overview of the minerals identified in fluvio-lacustrine samples and summarize the mineralogy of each unit moving up section.

The mineralogy of fluvio-lacustrine samples is variable within the stratigraphic section. Samples contain varying abundances of plagioclase, felsic igneous minerals, mafic igneous minerals, Fe-oxide minerals, phyllosilicates, sulfate minerals, the phosphate fluorapatite, halite, and X-ray amorphous materials (Fig. 14). Felsic minerals include 

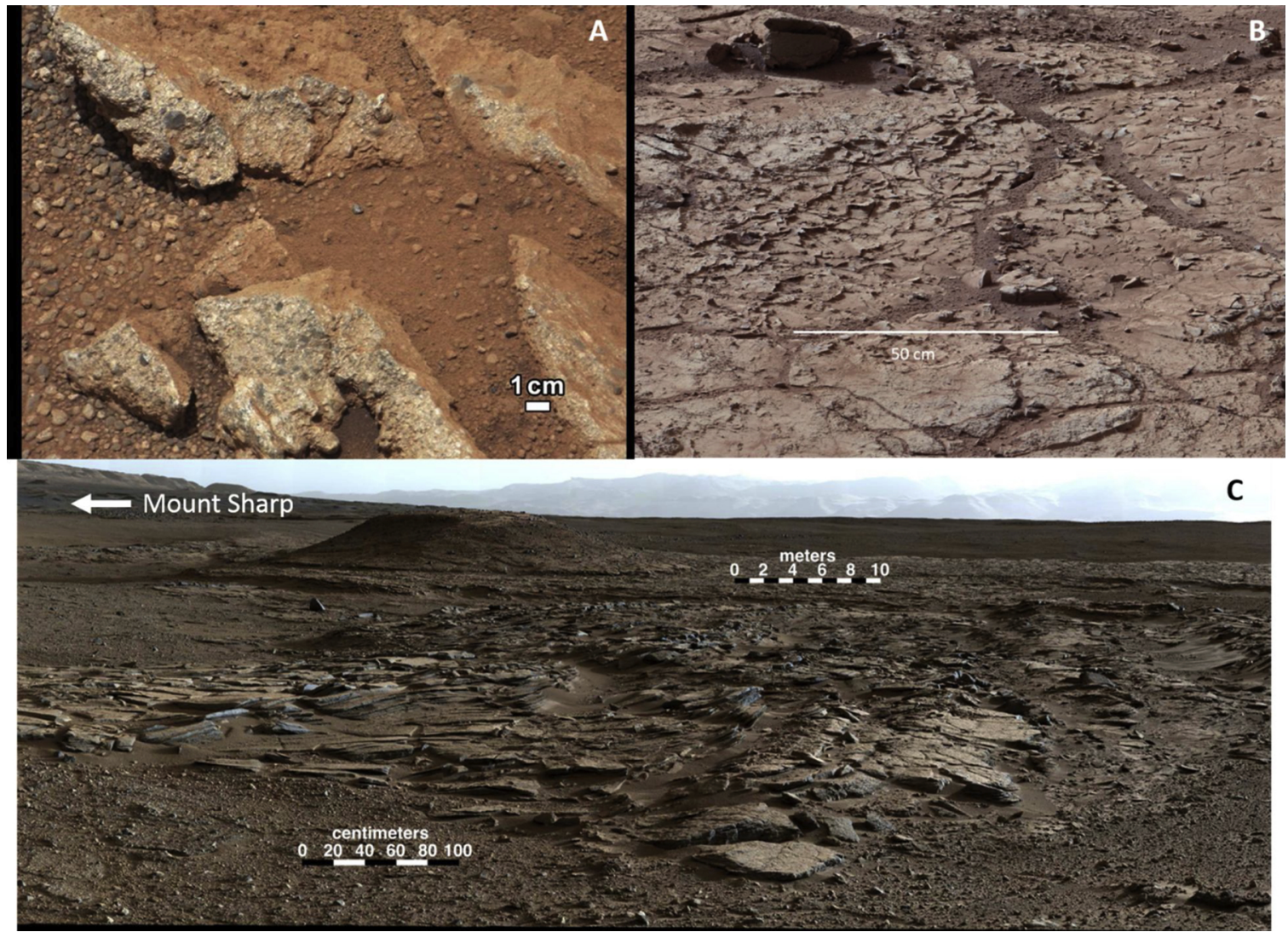

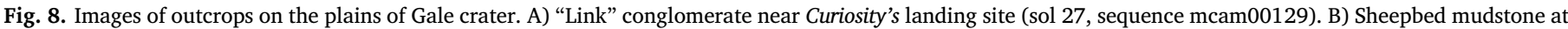
Yellowknife Bay (sol 153, mcam00848). C) Dipping sandstone beds at the Kimberley formation (sol 590, mcam02484). Image credits: NASA/JPL-Caltech/MSSS.

alkali feldspar (variety sanidine), tridymite, cristobalite, and trace amounts of quartz. Mafic igneous minerals identified include pyroxene and olivine. The CheMin team has reported on pyroxene compositions previously (Blake et al., 2013; Bish et al., 2013; Vaniman et al., 2014; Treiman et al., 2016; Rampe et al., 2017; Bristow et al., 2018; Morrison et al., 2018b; Rampe et al., 2018). Overlapping peaks of pyroxenes in CheMin X-ray diffraction patterns and the low angular resolution of the instrument, however, preclude confident identification of pyroxene phases or crystal chemistry. We report the published pyroxene subtype compositions for several samples in Table 3 , but caution that there is a great deal of uncertainty associated with them and they should not be used for detailed petrologic interpretations.

The most common Fe-oxide minerals include hematite and magnetite, but the Fe-oxyhydroxide mineral, akaganeite $[\beta-\mathrm{FeO}(\mathrm{OH}, \mathrm{Cl})]$, has been identified in the Bradbury group on the plains of Gale crater (Vaniman et al., 2014; Treiman et al., 2016) and very recently from the Pettegrove Point and Jura members of the Murray formation (Morris et al., 2019; Rampe et al., 2020). For samples that contain at least minor amounts of magnetite, the refined magnetite unit-cell parameters are smaller than those of stoichiometric magnetite, suggesting partial oxidation of the Fe(II) toward the Fe(III) defect-spinel maghemite. Alternatively, substitution of smaller cations such as $\mathrm{Cr}^{3+}, \mathrm{Mg}^{2+}$, or $\mathrm{Al}^{3+}$ could account for a smaller unit cell, although it is not clear whether sufficient amounts of these cations are present (Morrison et al., 2018a, b).

Phyllosilicates are readily identified in CheMin diffraction data by the presence and position of (001) peaks (Fig. 15), which are a measure of interlayer spacing along the c-axis of the crystal. Most patterns show a $\mathrm{d}(001)$ of $\sim 10 \AA$, which is consistent with a collapsed (i.e., dehydrated) swelling clay mineral (e.g., smectite) or illite. One sample from Yellowknife Bay, named "Cumberland," has a d(001) up to $\sim 13.5 \AA$ that may indicate intercalated metal-hydroxyl groups in the smectite interlayer site (Bristow et al., 2015). The low abundance of potassium in most samples suggests little, if any, illite is present (Bristow et al., 2015, 2018). The detection of collapsed smectite confirms the hypothesis that smectite on the martian surface is dehydrated based on orbital spectral data (e.g., Wray et al., 2009; Che et al., 2011). The position of the (02l) diffraction band, which is a measure of the b-axis of the crystal (Fig. 15), suggests a change from trioctahedral smectite to smectite with more dioctahedral character moving up section (Bristow et al., 2015, 2018). SAM evolved gas data show complementary evidence for changes in smectite structure and composition within the stratigraphic section based on the temperature of structural $\mathrm{H}_{2} \mathrm{O}$ release (Ming et al., 2014; Bristow et al., 2018). Phyllosilicates in the samples collected from the Hartmann's Valley member and the members that compose Vera Rubin ridge have $d(001)$ peaks at $\sim 9.6 \AA$, consistent with a completely collapsed smectite or Fe-pyrophyllite (Bristow et al., 2018; Rampe et al., 2020).

The Ca-sulfate minerals anhydrite, bassanite, and gypsum are common (Vaniman et al., 2014, 2018), especially up section, and jarosite is present in minor to trace amounts in many of the samples collected from the Murray formation on the lower slopes of Mount Sharp (Rampe et al., 2017; Bristow et al., 2018; Achilles et al., submitted, Rampe et al., 2020). Minor amounts of fluorapatite were identified in some samples from the Pahrump Hills member at the base of the Murray formation, and trace amounts of halite were identified in one sample from the Karasburg member in the Murray formation ("Quela").

X-ray amorphous materials are abundant $(\sim 20-60 \mathrm{wt} . \%)$ in all fluvio-lacustrine samples. X-ray amorphous materials are identified in CheMin diffraction patterns from the presence of a broad hump in the background centered between $\sim 22-26^{\circ} 2 \theta$ and scattering at low angles (Fig. 5). The identity of the X-ray amorphous materials is difficult to ascertain from XRD data alone because they generally do not have distinct XRD patterns. The relative position of the X-ray amorphous 

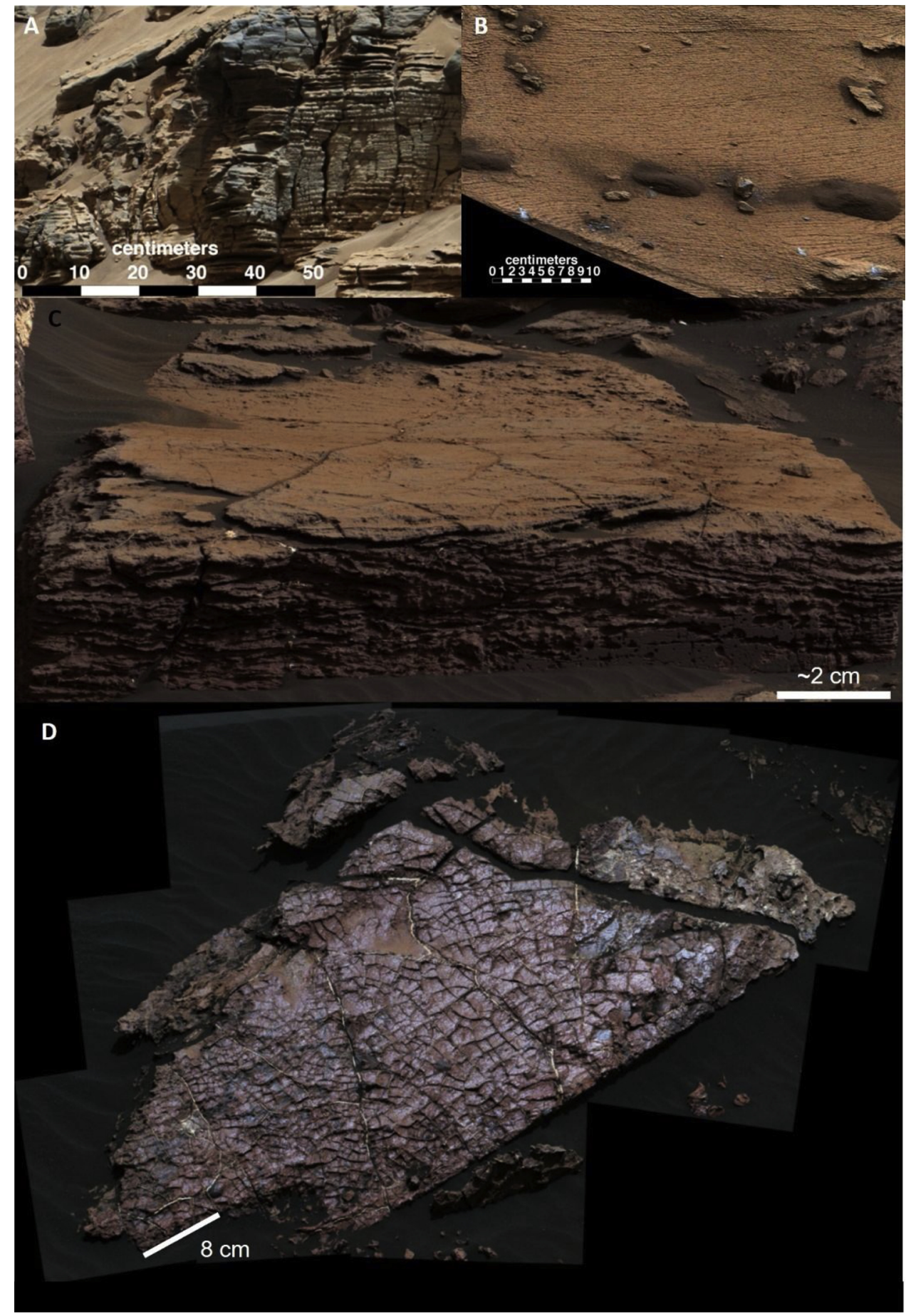

Fig. 9. Images of outcrops from the Murray formation. Thickly (A) and thinly (B) laminated mudstone deposits from the Pahrump Hills (sol 712, mcam03030; sol 792, mcam03445). C) Ripple cross-lamination in the Sutton Island member (sol 1477, mcam07413). D) Desiccation cracks in the "Old Soaker" target (sol 1555, mcam07981). Image credits: NASA/JPL-Caltech/MSSS.

hump can be used to discern relative $\mathrm{SiO}_{2}$ abundances in amorphous silicates, where high-SiO ${ }_{2}$ amorphous silicates (e.g., opal-A, rhyolitic glass) have a hump centered at lower angles, whereas amorphous silicates with lower $\mathrm{SiO}_{2}$ (e.g., basaltic glass) have a hump centered at higher angles. This trend should not be used, however, to characterize the amorphous component when multiple amorphous materials are present in the same sample, as is the case for samples from Gale crater. XRD patterns of amorphous sulfate, for example, look very similar to amorphous silicates (Morris et al., 2015).

Calculations of the composition of the X-ray amorphous component using CheMin mineral abundances and APXS bulk chemistry of the post-sieve or bulk powder dump piles demonstrate a large variation in compositions between samples (Table 6). There are many sources of error for the calculated amorphous component (e.g., abundance of crystalline phases, abundance of amorphous material, calculated crystal chemistry of major phases, assumed composition of phyllosilicates), so the calculated amorphous component likely represents the amorphous composition plus the residual error of the calculated composition based on the model mineralogy and mineral chemistry determined by Rietveld refinement. The aliquot of sample delivered to CheMin comes from the same material as the post-sieve or bulk powder dump piles, so the bulk APXS compositions of these dump piles are likely similar to those 
Table 1

Information about samples analyzed by CheMin.

\begin{tabular}{llll}
\hline $\begin{array}{l}\text { Sample } \\
\text { (abbreviation) }\end{array}$ & $\begin{array}{l}\text { Sol(s) } \\
\text { Collected }\end{array}$ & Elevation (m) & $\begin{array}{l}\text { Depositional } \\
\text { Environment }\end{array}$ \\
\hline Rocknest (RN) & $61,66,69,74$, & -4516.9 & $\begin{array}{l}\text { Modern eolian } \\
\text { (inactive) }\end{array}$ \\
& 93 & & Lacustrine \\
John Klein (JK) & 182 & -4519.5 & Lacustrine \\
Cumberland (CB) & 279 & -4519.5 & Reworked eolian and \\
Windjana (WJ) & 621 & -4481.5 & fluvial \\
& & & Lacustrine \\
Confidence Hills & 759 & -4460.3 & \\
$\quad$ (CH) & & & Lacustrine \\
Mojave2 (MJ) & 882 & -4459.4 & Lacustrine \\
Telegraph Peak (TP) & 908 & -4453.2 & Lacustrine \\
Buckskin (BK) & 1060 & -4446.8 & Ancient eolian \\
Big Sky (BS) & 1119 & -4434.7 & Ancient eolian (halo) \\
Greenhorn (GH) & 1137 & -4434.5 & Modern eolian (active) \\
Gobabeb (GB) & 1224 & -4423.8 & Ancient eolian (halo) \\
Lubango (LB) & 1320 & -4429.0 & Ancient eolian \\
Okoruso (OK) & 1332 & -4429.3 & Reworked eolian and \\
Oudam (OU) & 1361 & -4435.5 & fluvial \\
& & -4410.4 & Lacustrine \\
Marimba (MB) & 1422 & -4379.7 & Lacustrine \\
Quela (QL) & 1464 & -4360.8 & Lacustrine \\
Sebina (SB) & 1495 & -4300.0 & Modern eolian (active) \\
Ogunquit Beach (OG) & 1651 & -4192.5 & Lacustrine \\
Duluth (DU) & 2057 & -4169.9 & Lacustrine \\
Stoer (ST) & 2136 & -4147.0 & Lacustrine \\
Highfield (HF) & 2223 & 2261 & Lacustrine \\
Rock Hall (RH) & & & \\
\hline & & & \\
\hline
\end{tabular}

of the samples inside CheMin. Therefore, differences between the composition of the CheMin-analyzed sample and the APXS-analyzed sample are unlikely to be significant sources of error.

Despite some sources of error for these calculations, the results can be used to examine relative elemental enrichments and depletions between samples (e.g., Dehouck et al., 2014; Rampe et al., 2017; Yen et al., 2017). The amorphous component in all samples contains $\mathrm{SO}_{3}$, $\mathrm{FeO}_{\mathrm{T}}$, and $\mathrm{SiO}_{2}$, suggesting amorphous sulfates, nanophase Fe-oxides, and silicates are present in all samples. The amorphous component in many samples contains abundant $\mathrm{FeO}_{\mathrm{T}}$ (e.g., "Windjana," "Marimba," and "Duluth"), suggesting the presence of nanophase Fe-oxides and/or amorphous Fe-sulfates. The amorphous component in some samples is relatively enriched in $\mathrm{SiO}_{2}$ (e.g., "Buckskin" and "Oudam"), suggesting the presence of opal-A and/or rhyolitic glass. Aluminum abundances are relatively low in all samples, suggesting amorphous aluminosilicates like allophane and maskelynite do not make up a significant portion of the amorphous component. None of the calculated compositions of amorphous material is consistent with pure basaltic glass. Although some basaltic glass could be present, low amounts of $\mathrm{SiO}_{2}$, $\mathrm{Al}_{2} \mathrm{O}_{3}, \mathrm{MgO}$, and/or $\mathrm{CaO}$ in all samples preclude abundant basaltic glass. This finding is consistent with Mössbauer data collected by the Mars Exploration Rovers in Gusev crater and Meridiani Planum, which demonstrate that $\mathrm{Fe}$ is not present in basaltic glass at either landing site (Morris et al., 2006, 2008).

The dominant oxides present in the amorphous component in each sample could provide further information about aqueous conditions. High concentrations of $\mathrm{FeO}_{\mathrm{T}}$ suggest the presence of an amorphous $\mathrm{Fe}$ phase, like ferrihydrite. Ferrihydrite-like materials form by rapid hydrolysis of $\mathrm{Fe}^{3+}$ in solution (e.g., Schwertmann and Cornell, 2000). Aqueous $\mathrm{Fe}^{3+}$ can be mobilized at low $\mathrm{pH}$, or it could form by rapid oxidation and hydrolysis of $\mathrm{Fe}^{2+}$ in solution that was sourced from the alteration of mafic igneous minerals. Elevated $\mathrm{FeO}_{\mathrm{T}}$ and $\mathrm{SO}_{3}$ in the amorphous component could indicate the presence of amorphous $\mathrm{Fe}$ sulfate, which would implicate acidic conditions. Abundant $\mathrm{SiO}_{2}$ in the amorphous component suggests the presence of opaline silica. There are no diffraction properties to refine the identification of opal-A, but in some samples, opal-CT has been identified and based on characteristic diffraction peaks in this paracrystalline material (Table 5). Opaline silica can form in a variety of environments, and is an expected alteration product of basaltic sediments because Ca-rich plagioclase and mafic igneous silicates are more susceptible to dissolution than felsic minerals (e.g., McLennan, 2003). The presence of abundant amorphous silica may signify aqueous alteration and dissolution of basaltic minerals or it may be a primary volcanic glass in the case of the "Buckskin" sample.

The abundance of X-ray amorphous materials in the ancient rock samples is especially perplexing because amorphous materials in rocks on Earth mature into crystalline phases over time. Opaline silica, for example, transforms to quartz through a dissolution-precipitation reaction in early diagenetic environments (e.g., Kastner et al., 1977). On Earth, amorphous silica is not usually found in rocks over a few million years old and is absent in rocks over $\sim 145$ Ma old (e.g., Tosca and Knoll, 2009). Compositionally complex amorphous materials, similar to those identified in Gale crater, have been identified in modern subglacial sediments formed from basaltic andesite and andesite sources in the Three Sisters Volcanic Complex in Oregon (Smith et al., 2018). These materials are enriched in $\mathrm{SiO}_{2}(\sim 50-60$ wt. $\%), \mathrm{Al}_{2} \mathrm{O}_{3}(\sim 15$ wt.

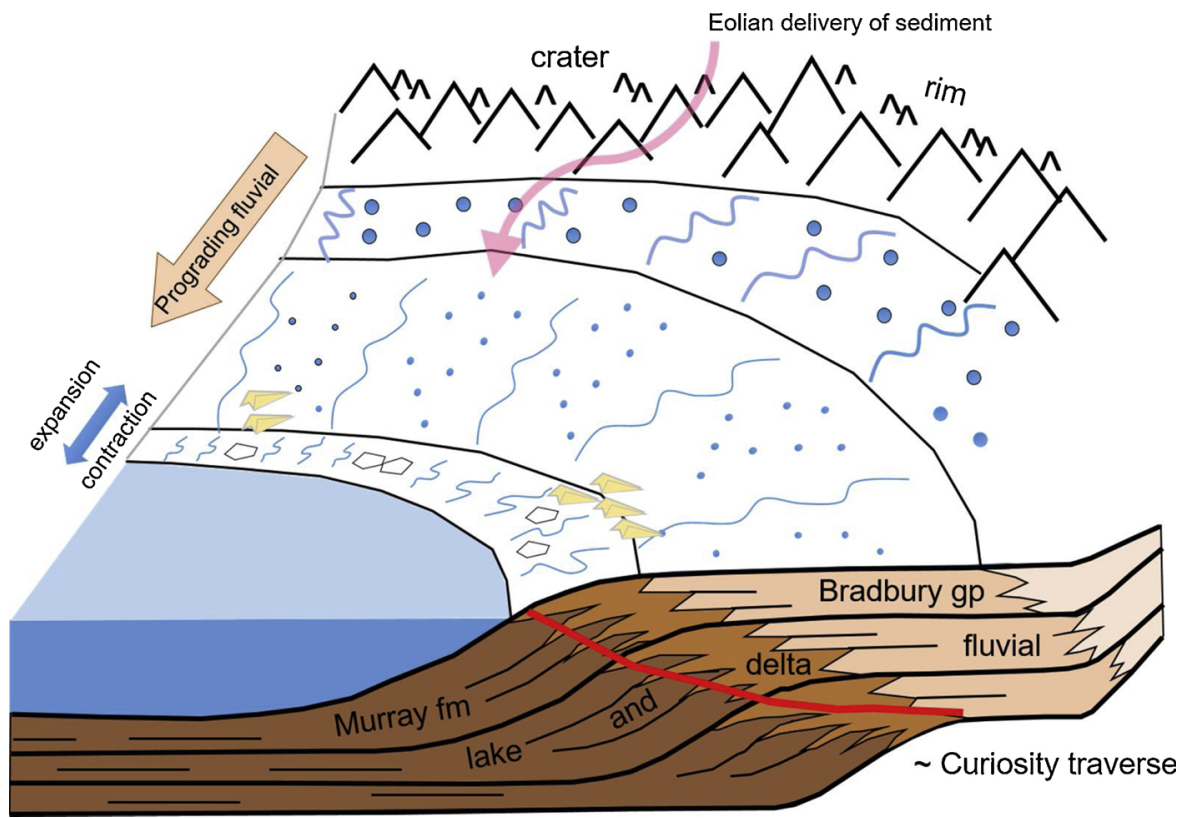

Fig. 10. Schematic showing the depositional environments preserved by the Bradbury Group and Murray formation. The Bradbury group is dominated by fluviodeltaic deposits as rivers and streams emanating from the rim delivered sediments across the plains and into lakes on the crater floor. The Murray formation is dominated by lacustrine deposits. Desiccation features and salts would have precipitated along the lake margin. Curiosity's traverse is drawn in red, showing the beginning of the traverse in fluvio-deltaic deposits then transitioning to lacustrine and lake-margin deposits. Credit: C. Fedo. (For interpretation of the references to colour in this figure legend, the reader is referred to the web version of this article.). 

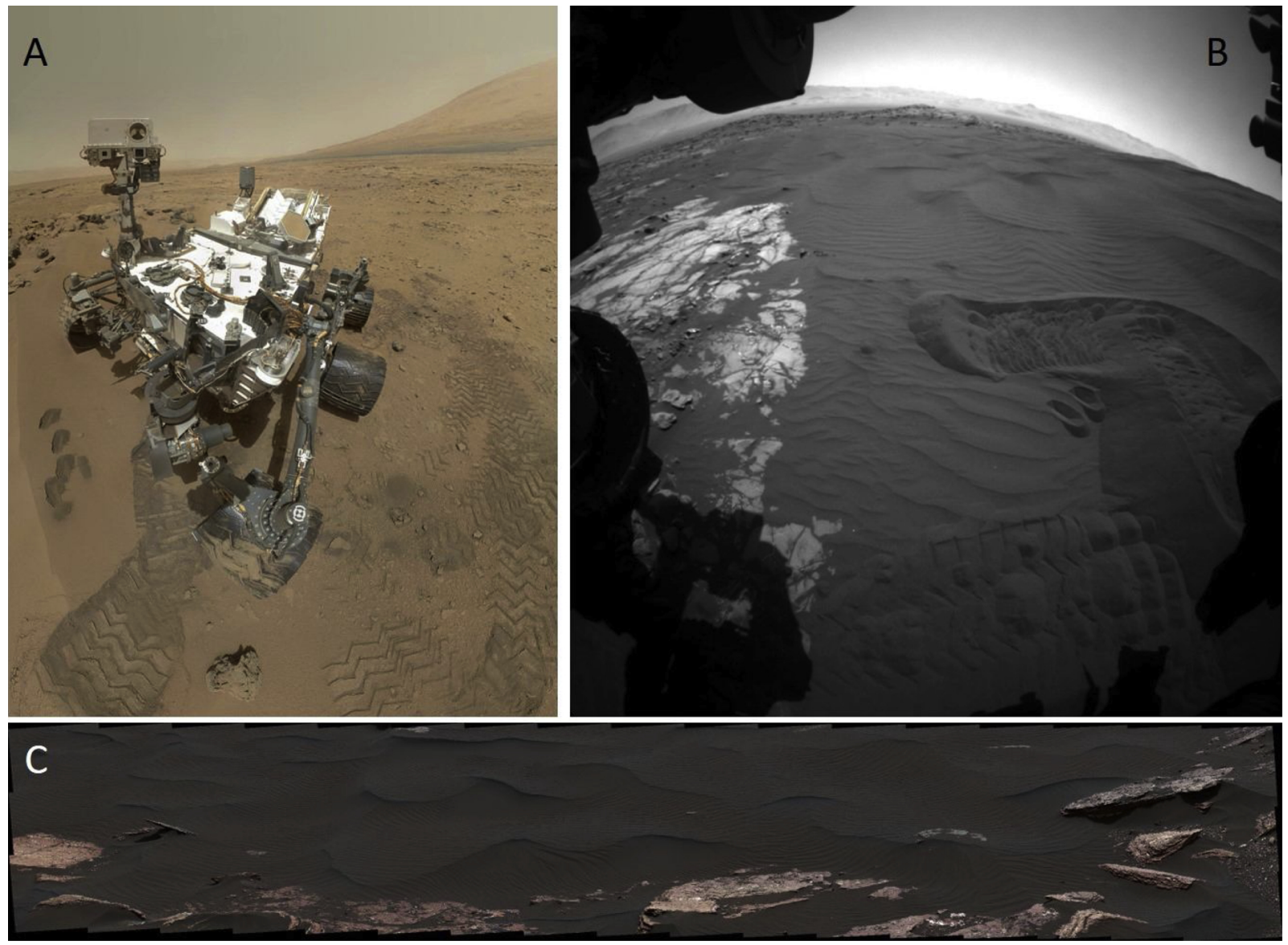

Fig. 11. Curiosity's sampling sites of modern eolian materials. A) Curiosity selfie taken by MAHLI showing scoops from "Rocknest" (RN) sand shadow (sol 84). Curiosity's selfies are a mosaic of dozens of MAHLI images. B) Front Hazcam image showing wheel scuff and scoops of "Gobabeb" (GB) from Namib Dune (sol 1229, fhaz00323). C) Meter-scale ripples at Mount Desert Island sand patch, from which "Ogunquit Beach" (OG) was scooped (sol 1647, mcam08526). Images credit: NASA/JPL-Caltech/MSSS.

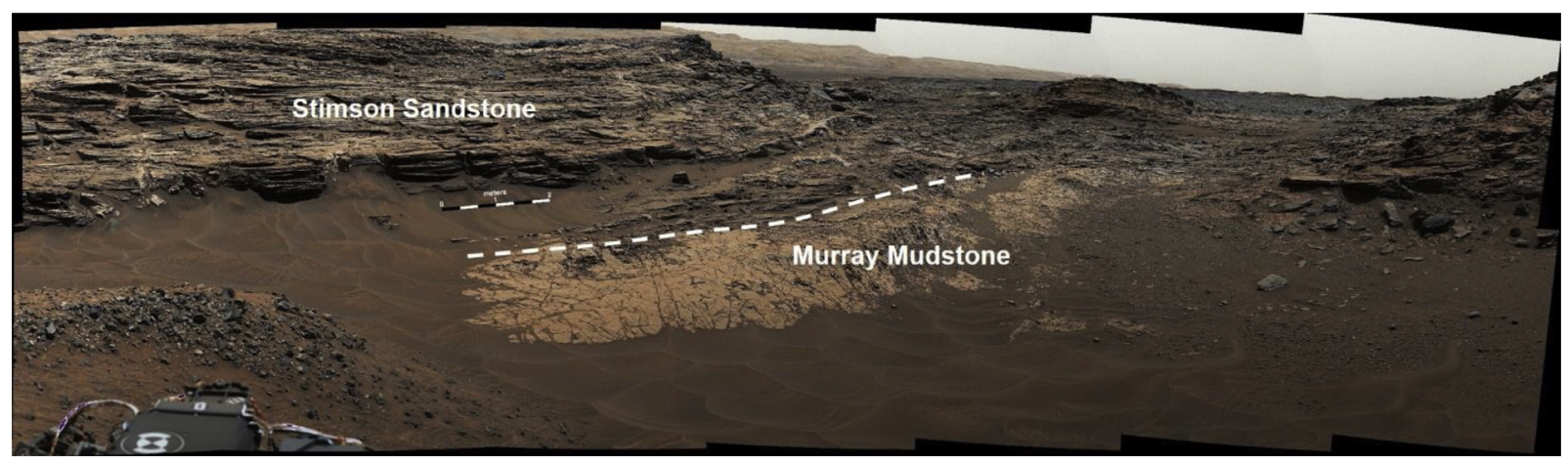

Fig. 12. Unconformable contact between the Murray and Stimson formations at the Marias Pass location at the top of the Pahrump Hills member (sol 992, mcam04393). The contact is denoted as a dashed line. The "Buckskin" sample was drilled from this location. Scale bar is $2 \mathrm{~m}$. Image credit: NASA/JPL-Caltech/MSSS.

$\%$ ), and $\mathrm{FeO}_{\mathrm{T}}\left(\sim 15\right.$ wt.\%) and have lesser amounts of $\mathrm{CaO}, \mathrm{MgO}, \mathrm{Na}_{2} \mathrm{O}$, and $\mathrm{K}_{2} \mathrm{O}$. Transmission electron microscopy of the sediments indicates that much of the amorphous component is secondary in nature, suggesting it formed from water-rock interactions at relatively low temperatures. Although these materials have more $\mathrm{Al}_{2} \mathrm{O}_{3}$ and less $\mathrm{SO}_{3}$ than amorphous materials in Gale crater, the formation of compositionally heterogeneous amorphous materials in cold and icy environments may explain some portion of the amorphous component in Gale crater. Their preservation for perhaps billions of years, however, suggests groundwater was intermittent and was not present in sufficient volumes to cause the maturation of amorphous materials to crystalline phases.

\subsection{Modern eolian samples}

The mineralogy of modern eolian sediments can be used to evaluate the extent of sorting and grain segregation in a single bedform and across dune fields, the relative contribution of underlying bedrock to the sediment, and the composition of modern sediment sources. The insitu measurements by CheMin also allow us to ground truth orbital remote sensing measurements and clarify differences between the insitu and orbital measurements. CheMin has analyzed three modern eolian sediments. "Rocknest" was scooped from an inactive sand shadow near the landing site, whereas "Gobabeb" and "Ogunquit 


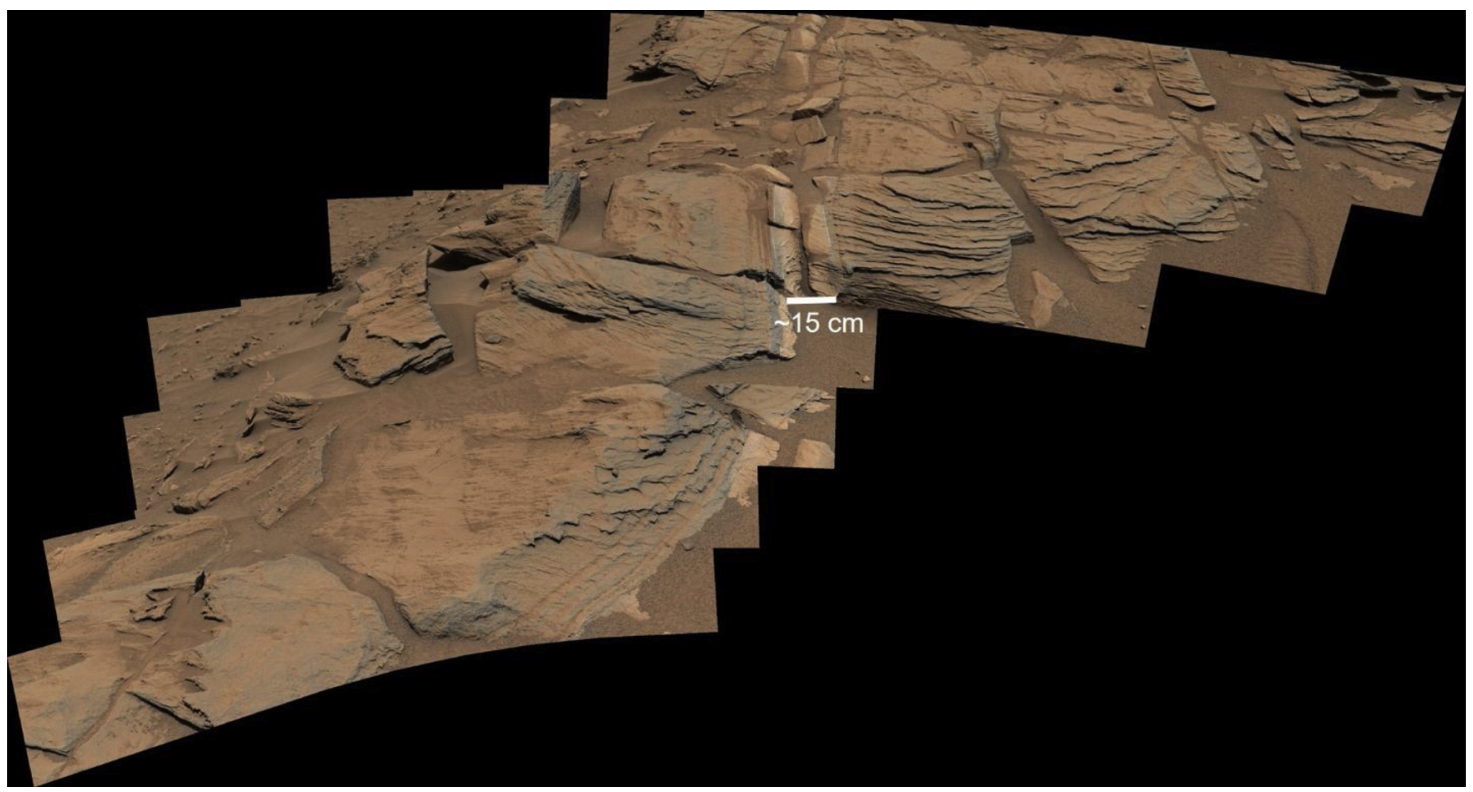

Fig. 13. Mastcam mosaic of a fracture-associated halo observed at Teakettle Junction (sol 747, mcam03215). Image credit: NASA/JPL-Caltech/MSSS.

Beach" were scooped from different locations in the active Bagnold Dune Field. "Gobabeb" was scooped from a barchanoid dune named Namib Dune near the trailing edge of the dune field and "Ogunquit Beach" from a ripple field downwind of Namib Dune. All three samples have similar mineralogy and are dominated by basaltic igneous minerals and X-ray amorphous materials with minor amounts of Fe-oxide minerals (magnetite and hematite are present in all samples and ilmenite is present in "Rocknest"), anhydrite, and quartz (Table 7; Fig. 16). Mineralogical results from the modern eolian samples are reported by Blake et al. (2013); Bish et al. (2013); Achilles et al. (2017); Morrison et al. (2018b), and Rampe et al. (2018).

The basaltic igneous minerals present in each sample include plagioclase, pyroxene, and olivine. Plagioclase constitutes $38-47 \mathrm{wt} . \%$ of the crystalline fraction, and the calculated plagioclase compositions (Table 8) from the refined unit-cell parameters for each sample are $\mathrm{An}_{49(4)}, \mathrm{An}_{63(5)}$, and $\mathrm{An}_{48(5)}$ for Rocknest, Gobabeb, and Ogunquit Beach, respectively. Each sample has $\sim 26-33$ wt.\% pyroxene. The presence of both augite and pigeonite were reported previously (Bish et al., 2013; Blake et al., 2013; Achilles et al., 2017; Morrison et al., 2018b; Rampe et al., 2018) but, again, we caution that the low angular resolution of the CheMin instrument and overlapping pyroxene peaks reduces our confidence in these identifications and their calculated crystal compositions from refined unit-cell parameters. Olivine is present in abundances of $18-26 \mathrm{wt} . \%$ and the olivine composition is the same between all samples within a $1 \sigma$ error $\left(\mathrm{Fo}_{54-60}\right)$.

The major constituents of the calculated amorphous components are $\mathrm{SiO}_{2}, \mathrm{FeO}_{\mathrm{T}}, \mathrm{Al}_{2} \mathrm{O}_{3}$, and $\mathrm{SO}_{3}$ (Table 9). Thus, like the amorphous materials in fluvio-lacustrine samples, they are not consistent with any one single X-ray amorphous material. When compared to an Adirondack basalt composition in Gusev crater, basaltic glass is inconsistent with the calculated amorphous compositions. The Rocknest amorphous component is too depleted in $\mathrm{SiO}_{2}$, the Gobabeb amorphous component is too enriched in $\mathrm{SiO}_{2}$, and the amorphous components from all modern eolian samples are too depleted in $\mathrm{Al}_{2} \mathrm{O}_{3}, \mathrm{MgO}$, and $\mathrm{CaO}$ and

Table 2

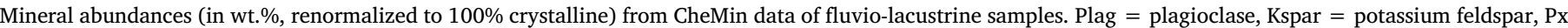

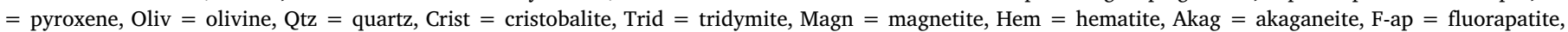

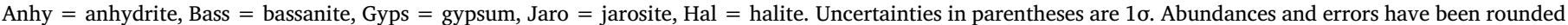
to the nearest whole number. The symbol “-" indicates that phase is at or below the detection limit of CheMin.

\begin{tabular}{|c|c|c|c|c|c|c|c|c|c|c|c|c|c|c|c|}
\hline & $\mathrm{JK}^{1}$ & $\mathrm{CB}^{1}$ & $\mathrm{WJ}^{1}$ & $\mathrm{CH}^{1}$ & $\mathrm{MJ}^{1}$ & $\mathrm{TP}^{1}$ & $\mathrm{BK}^{1}$ & $\mathrm{OU}^{2}$ & $\mathrm{MB}^{2}$ & $\mathrm{QL}^{2}$ & $\mathrm{SB}^{2}$ & $\mathrm{DU}^{3}$ & $\mathrm{ST}^{3}$ & $\mathrm{HF}^{3}$ & $\mathrm{RH}^{3}$ \\
\hline Plag & $44(1)$ & $43(1)$ & $6(1)$ & $38(2)$ & $55(2)$ & $44(2)$ & $43(2)$ & $52(1)$ & $44(3)$ & $44(3)$ & $38(2)$ & $56(1)$ & $45(2)$ & $47(2)$ & $38(4)$ \\
\hline Kspar & $4(1)$ & $5(1)$ & $26(1)$ & $9(1)$ & - & $8(2)$ & $8(1)$ & - & $8(2)$ & $7(1)$ & $4(1)$ & $7(1)$ & $3(3)$ & $3(1)$ & - \\
\hline $\mathrm{Px}$ & $26(2)$ & $31(2)$ & $42(3)$ & $26(7)$ & $16(2)$ & $13(3)$ & - & $8(2)$ & $2(2)$ & $7(2)$ & $7(4)$ & $10(3)$ & $6(2)$ & $10(3)$ & $17(2)$ \\
\hline Oliv & $8(0)$ & $3(1)$ & $7(2)$ & $2(1)$ & $1(1)$ & $2(1)$ & - & - & - & - & - & - & - & - & - \\
\hline Qtz & - & - & - & $1(1)$ & $2(0)$ & $1(0)$ & - & $2(0)$ & $2(1)$ & $1(1)$ & $1(0)$ & $2(1)$ & $1(1)$ & 1(1) & - \\
\hline Crist & - & - & - & - & - & $12(2)$ & $6(0)$ & - & - & - & - & - & - & - & - \\
\hline Trid & - & - & - & - & - & - & $34(1)$ & - & - & - & - & - & - & - & - \\
\hline Magn & $9(1)$ & $11(0)$ & $16(1)$ & $6(1)$ & $7(1)$ & $13(1)$ & $7(0)$ & - & - & - & - & $2(1)$ & $1(1)$ & 1(1) & - \\
\hline Hem & $1(0)$ & $1(0)$ & $2(1)$ & $13(1)$ & $7(1)$ & $2(0)$ & - & $26(1)$ & $20(1)$ & $23(2)$ & $24(2)$ & $13(2)$ & $28(1)$ & $20(1)$ & $5(0)$ \\
\hline Akag & $1(0)$ & 2(1) & 1(1) & - & - & - & - & - & - & - & - & - & $2(1)$ & - & $11(1)$ \\
\hline F-ap & - & - & - & $2(1)$ & $4(1)$ & $3(0)$ & - & - & - & - & - & - & - & - & $3(1)$ \\
\hline Anhy & $4(0)$ & $1(0)$ & $1(0)$ & - & - & - & $2(0)$ & $6(1)$ & $12(1)$ & $9(1)$ & $17(1)$ & $3(1)$ & $6(1)$ & $8(1)$ & 21(3) \\
\hline Bass & $3(0)$ & $2(0)$ & $1(0)$ & - & - & - & - & - & $4(1)$ & $6(0)$ & $4(0)$ & $7(1)$ & $1(0)$ & $3(1)$ & - \\
\hline Gyps & - & - & - & - & - & - & - & $6(0)$ & $7(1)$ & 1(1) & $4(0)$ & - & $4(1)$ & $5(1)$ & - \\
\hline Jaro & - & - & - & $2(1)$ & $8(2)$ & $2(2)$ & - & - & $2(1)$ & $1(1)$ & $3(1)$ & - & $2(1)$ & - & $4(1)$ \\
\hline Hal & - & - & - & - & - & - & - & - & - & $1(0)$ & - & - & - & - & - \\
\hline
\end{tabular}

\footnotetext{
1 From Morrison et al. (2018b).

2 From Achilles et al. (submitted).

3 From Rampe et al. (2020).
} 
Table 3

Crystal chemistry of major igneous phases in fluvio-lacustrine samples calculated from refined unit-cell parameters. Uncertainties in parentheses are $1 \sigma$.

\begin{tabular}{|c|c|c|c|c|c|c|}
\hline & Plag & K-spar & Augite & Pigeonite & OPX & Olivine \\
\hline $\mathrm{JK}^{1}$ & $\mathrm{An}_{43(4)}$ & $\mathrm{Or}_{53(18)}$ & & $\mathrm{En}_{60(8)} \mathrm{Fs}_{35(9)} \mathrm{Wo}_{5(4)}$ & $\mathrm{En}_{31(3)} \mathrm{Fs}_{69}$ & $\mathrm{Fo}_{60(12)}$ \\
\hline $\mathrm{CB}^{1}$ & $\mathrm{An}_{35(5)}$ & $\mathrm{Or}_{77(19)}$ & & $\mathrm{En}_{58(9)} \mathrm{Fs}_{37(10)} \mathrm{Wo}_{6(5)}$ & $\mathrm{En}_{27(5)} \mathrm{Fs}_{73}$ & $\mathrm{Fo}_{60(21)}$ \\
\hline $\mathrm{WJ}^{1}$ & $\mathrm{An}_{28(45)}$ & $\mathrm{Or}_{87(5)}$ & $\mathrm{En}_{50(7)} \mathrm{Fs}_{9(9)} \mathrm{Wo}_{42(6)}$ & $\mathrm{En}_{70(12)} \mathrm{Fs}_{28(13)} \mathrm{Wo}_{3(5)}$ & & $\mathrm{Fo}_{72(8)}$ \\
\hline $\mathrm{CH}^{1}$ & $\mathrm{An}_{40(4)}$ & $\mathrm{Or}_{82(11)}$ & & $\mathrm{En}_{57(19)} \mathrm{Fs}_{43(19)} \mathrm{Wo}_{0(6)}$ & & \\
\hline $\mathrm{MJ}^{1}$ & $\mathrm{An}_{42(3)}$ & & & $\mathrm{En}_{60(18)} \mathrm{Fs}_{41(19)} \mathrm{Wo}_{0(6)}$ & & \\
\hline $\mathrm{TP}^{1}$ & $\mathrm{An}_{37(3)}$ & $\mathrm{Or}_{69(11)}$ & & $\mathrm{En}_{58(23)} \mathrm{Fs}_{43(24)} \mathrm{Wo}_{\mathrm{O}(7)}$ & & \\
\hline $\mathrm{BK}^{1}$ & $\mathrm{An}_{41(3)}$ & $\mathrm{Or}_{77(14)}$ & & & & \\
\hline $\mathrm{OU}^{2}$ & $\mathrm{An}_{40(7)}$ & & & & & \\
\hline $\mathrm{MB}^{2}$ & $\mathrm{An}_{39(5)}$ & & & & & \\
\hline $\mathrm{QL}^{2}$ & $\mathrm{An}_{39(6)}$ & & & & & \\
\hline $\mathrm{SB}^{2}$ & $\mathrm{An}_{42(6)}$ & & & & & \\
\hline
\end{tabular}

1 From Morrison et al. (2018b).

2 From Achilles et al. (2020).

Table 4

Magnetite unit-cell parameters and crystal chemistry for fluvio-lacustrine samples ${ }^{1}$. Uncertainties in parentheses are $1 \sigma$.

\begin{tabular}{lll}
\hline Sample & $a$ cell length (in $\AA)^{2}$ & Chemical Formula \\
\hline JK & $8.372(2)$ & $\mathrm{Fe}_{2.82(5)} \square_{0.18} \mathrm{O}_{4}$ \\
CB & $8.369(2)$ & $\mathrm{Fe}_{2.81(5)} \square_{0.19} \mathrm{O}_{4}$ \\
WJ & $8.373(1)$ & $\mathrm{Fe}_{2.83(5)} \square_{0.17} \mathrm{O}_{4}$ \\
CH & $8.365(3)$ & $\mathrm{Fe}_{2.79(5)} \square_{0.21} \mathrm{O}_{4}$ \\
MJ & $8.357(2)$ & $\mathrm{Fe}_{2.76(5)} \square_{0.24} \mathrm{O}_{4}$ \\
TP & $8.355(1)$ & $\mathrm{Fe}_{2.75(5)} \square_{0.25} \mathrm{O}_{4}$ \\
BK & $8.359(1)$ & $\mathrm{Fe}_{2.77(5)} \square_{0.23} \mathrm{O}_{4}$ \\
\hline
\end{tabular}

1 From Morrison et al. (2018b).

2 The a cell length for stoichiometric magnetite is $8.3969 \AA$.

Table 5

X-ray amorphous and phyllosilicate abundances in fluvio-lacustrine samples from FULLPAT analyses*. Uncertainties in parentheses are $1 \sigma$. The symbol "-” indicates that material was not detected in FULLPAT models.

\begin{tabular}{llll}
\hline Sample & Phyllosilicate & Amorphous & Opal-CT \\
\hline $\mathrm{JK}^{1}$ & $22(2)$ & 28 & - \\
$\mathrm{CB}^{1}$ & $18(2)$ & 31 & - \\
$\mathrm{WJ}^{2}$ & $10(2)$ & 15 & - \\
$\mathrm{CH}^{3}$ & $8(2)$ & $39(15)$ & - \\
$\mathrm{MJ}^{3}$ & $5(1)$ & 53 & - \\
$\mathrm{TP}^{3}$ & - & $27(15)$ & $11(2)$ \\
$\mathrm{BK}^{4}$ & - & 54 & $6(1)$ \\
$\mathrm{OU}^{5,6}$ & $3(1)$ & $44(11)$ & $7(1)$ \\
$\mathrm{MB}^{5,6}$ & $28(3)$ & $40(10)$ & - \\
$\mathrm{QL}^{5,6}$ & $16(2)$ & $52(13)$ & - \\
$\mathrm{SB}^{5,6}$ & $19(2)$ & $51(13)$ & - \\
$\mathrm{DU}^{7}$ & $15(4)$ & 37 & - \\
$\mathrm{ST}^{7}$ & $10(3)$ & 38 & - \\
$\mathrm{HF}^{7}$ & $5(1)$ & 49 & $4(1)$ \\
$\mathrm{RH}^{7}$ & $13(3)$ & $34(8)$ & - \\
\end{tabular}

* Abundances of amorphous phases for JK, CB, WJ, MJ, BK, DU, ST, and HF were constrained by CheMin crystalline abundances and APXS bulk chemistry, because the FULLPAT-derived values resulted in compositions with negative oxide values.

1 From Vaniman et al. (2014).

2 From Treiman et al. (2016).

3 From Rampe et al. (2017).

4 From Morris et al. (2016).

5 From Bristow et al. (2018).

${ }^{6}$ From Achilles et al. (submitted).

7 From Morris et al. (2019).

are too enriched in $\mathrm{SO}_{3}$. This composition suggests that multiple X-ray amorphous materials constitute the X-ray amorphous component, including volcanic and/or impact glass, nanophase Fe-oxides, and amorphous sulfates. There are clear differences in the compositions of the amorphous components in active eolian samples ("Gobabeb" and "Ogunquit Beach") and in the inactive eolian sample ("Rocknest"). The amorphous component of the active samples is more enriched in $\mathrm{SiO}_{2}$, whereas the amorphous component of the inactive sample is more enriched in $\mathrm{SO}_{3}$ and $\mathrm{Cl}$. The composition of dust on Curiosity's observation tray as measured by APXS is enriched in $\mathrm{SO}_{3}$ and $\mathrm{Cl}$ (Berger et al., 2016), so this difference in composition between the active and inactive eolian samples is a result of higher dust contents in the inactive sediments (Achilles et al., 2017).

\subsection{Ancient eolian samples}

Curiosity drilled two pairs of samples from the Stimson formation, a lithified eolian dune field that unconformably overlies the Murray formation. These samples were selected because of their association with light-toned alteration halos parallel to fractures in the rock (Fig. 13). One sample of each pair was collected from parent rock and the second from within the alteration halo: "Big Sky" (parent rock) was drilled $2 \mathrm{~m}$ from "Greenhorn" (alteration halo), and "Okoruso" (parent rock) was drilled $3 \mathrm{~m}$ from "Lubango" (alteration halo), and the "Okoruso"/"Lubango" pair was collected $\sim 650 \mathrm{~m}$ southwest of "Big Sky"/"Greenhorn." APXS and ChemCam measurements were also made in parent rock and in the alteration halos to identify geochemical trends associated with the processes that formed the halos. The mineralogical and geochemical trends observed by Curiosity are reported in detail by Yen et al. (2017).

CheMin analyses of the parent eolian sandstone samples ("Big Sky" and "Okoruso") show that they are dominated by igneous minerals, magnetite, and X-ray amorphous materials (Table 10). The parent sandstone contains abundant plagioclase feldspar and pyroxene (modeled as pigeonite and orthopyroxene; Table 11) and lacks olivine. Magnetite constitutes $\sim 15$ wt.\% of the crystalline component, and it may have formed diagenetically from the dissolution of olivine and partial oxidation of Fe(II)-bearing fluids (Yen et al., 2017; Hausrath et al., 2018). The bulk sample comprises $\sim 20$ to 35 wt.\% X-ray amorphous materials. The X-ray amorphous component is depleted in $\mathrm{SiO}_{2}$ relative to a basaltic composition and contains abundant $\mathrm{FeO}_{\mathrm{T}}$ and $\mathrm{MgO}$ (Table 12), which is also consistent with alteration of olivine. The amorphous component also contains $\mathrm{SO}_{3}$, suggesting nanophase $\mathrm{Fe}$ oxides and amorphous sulfates are present in the parent sandstone. These amorphous materials, in addition to the magnetite, are likely cementing agents. Minor amounts of sanidine, hematite, quartz, fluorapatite, and Ca-sulfate are also present in the parent sandstone.

The alteration halos have a distinctly different mineralogy and geochemical composition from the parent sandstone. The samples drilled from halos show a significant decrease in igneous mineral abundance (particularly for pyroxene), an enrichment in Ca- and mixed-cation sulfates, and a three-fold increase in X-ray amorphous materials. The calculated composition of the X-ray amorphous 
Table 6

Calculated X-ray amorphous component composition for fluvio-lacustrine samples, renormalized to $100 \%$.

\begin{tabular}{|c|c|c|c|c|c|c|c|c|c|c|c|c|c|c|c|}
\hline & $\mathrm{JK}^{1}$ & $\mathrm{CB}^{1}$ & $\mathrm{WJ}^{1}$ & $\mathrm{CH}^{1}$ & $\mathrm{MJ}^{1}$ & $\mathrm{TP}^{1}$ & $\mathrm{BK}^{1}$ & $\mathrm{OU}^{2}$ & $\mathrm{MB}^{2}$ & $\mathrm{QL}^{2}$ & $\mathrm{SB}^{2}$ & $\mathrm{DU}^{3}$ & $\mathrm{ST}^{3}$ & $\mathrm{HF}^{3}$ & $\mathrm{RH}^{3}$ \\
\hline $\mathrm{SiO}_{2}$ & 33.0 & 25.6 & 3.6 & 53.2 & 55.7 & 53.0 & 75.9 & 64.3 & 45.4 & 45.4 & 49.8 & 34.3 & 55.0 & 61.7 & 38.1 \\
\hline $\mathrm{TiO}_{2}$ & 3.3 & 3.7 & 5.2 & 3.1 & 2.5 & 5.9 & 2.8 & 2.1 & 1.8 & 2.0 & 2.1 & 2.6 & 2.7 & 1.7 & 2.8 \\
\hline $\mathrm{Al}_{2} \mathrm{O}_{3}$ & 0.0 & 0.0 & 3.9 & 5.7 & 7.2 & 1.9 & 0.0 & 5.4 & 5.8 & 4.0 & 4.4 & 0.0 & 5.1 & 7.9 & 5.2 \\
\hline $\mathrm{Cr}_{2} \mathrm{O}_{3}$ & 1.5 & 1.7 & 2.4 & 1.1 & 0.8 & 1.7 & 0.2 & 0.6 & 0.6 & 0.6 & 0.6 & 0.8 & 0.9 & 0.6 & 0.9 \\
\hline $\mathrm{FeO}_{\mathrm{T}}$ & 20.9 & 18.0 & 43.1 & 13.7 & 12.3 & 17.1 & 4.8 & 11.2 & 29.7 & 20.2 & 18.8 & 26.1 & 3.0 & 10.2 & 17.5 \\
\hline $\mathrm{MnO}$ & 1.0 & 1.1 & 2.7 & 1.0 & 0.8 & 1.2 & 0.2 & 0.4 & 0.1 & 0.4 & 0.3 & 0.5 & 0.4 & 0.3 & 0.2 \\
\hline $\mathrm{MgO}$ & 13.5 & 17.5 & 17.7 & 4.8 & 5.8 & 3.5 & 1.5 & 8.3 & 0.0 & 1.7 & 2.6 & 4.0 & 11.1 & 6.7 & 5.4 \\
\hline $\mathrm{CaO}$ & 9.2 & 11.1 & 0.6 & 0.8 & 0.0 & 1.4 & 2.1 & 0.0 & 3.9 & 7.6 & 5.8 & 8.0 & 4.4 & 1.5 & 2.9 \\
\hline $\mathrm{Na}_{2} \mathrm{O}$ & 2.3 & 1.7 & 1.0 & 2.1 & 1.8 & 2.3 & 1.2 & 1.7 & 2.3 & 1.9 & 2.2 & 0.1 & 2.0 & 1.4 & 2.3 \\
\hline $\mathrm{K}_{2} \mathrm{O}$ & 0.9 & 0.5 & 0.0 & 0.0 & 1.1 & 0.0 & 0.8 & 1.7 & 0.9 & 0.8 & 0.9 & 1.3 & 1.2 & 1.3 & 0.4 \\
\hline $\mathrm{P}_{2} \mathrm{O}_{5}$ & 2.9 & 3.2 & 3.1 & 1.0 & 0.8 & 1.4 & 2.2 & 1.0 & 1.8 & 2.1 & 1.2 & 2.8 & 2.2 & 1.6 & 0.2 \\
\hline $\mathrm{SO}_{3}$ & 10.0 & 11.5 & 13.9 & 12.3 & 10.3 & 9.2 & 7.8 & 2.5 & 6.9 & 11.8 & 9.4 & 17.3 & 10.6 & 3.3 & 23.4 \\
\hline $\mathrm{Cl}$ & 1.6 & 4.4 & 2.8 & 1.1 & 0.9 & 1.4 & 0.5 & 0.7 & 0.8 & 1.7 & 2.0 & 2.2 & 1.3 & 1.8 & 0.7 \\
\hline $\mathrm{F}$ & 0.0 & 0.0 & 0.0 & 0.1 & 0.2 & 0.1 & 0.0 & 0.0 & 0.0 & 0.0 & 0.0 & 0.0 & 0.0 & 0.0 & 0.0 \\
\hline
\end{tabular}

\footnotetext{
1 From Morrison et al. (2018b).

${ }^{2}$ From Achilles et al. (submitted).

3 From Rampe et al. (2020).
}

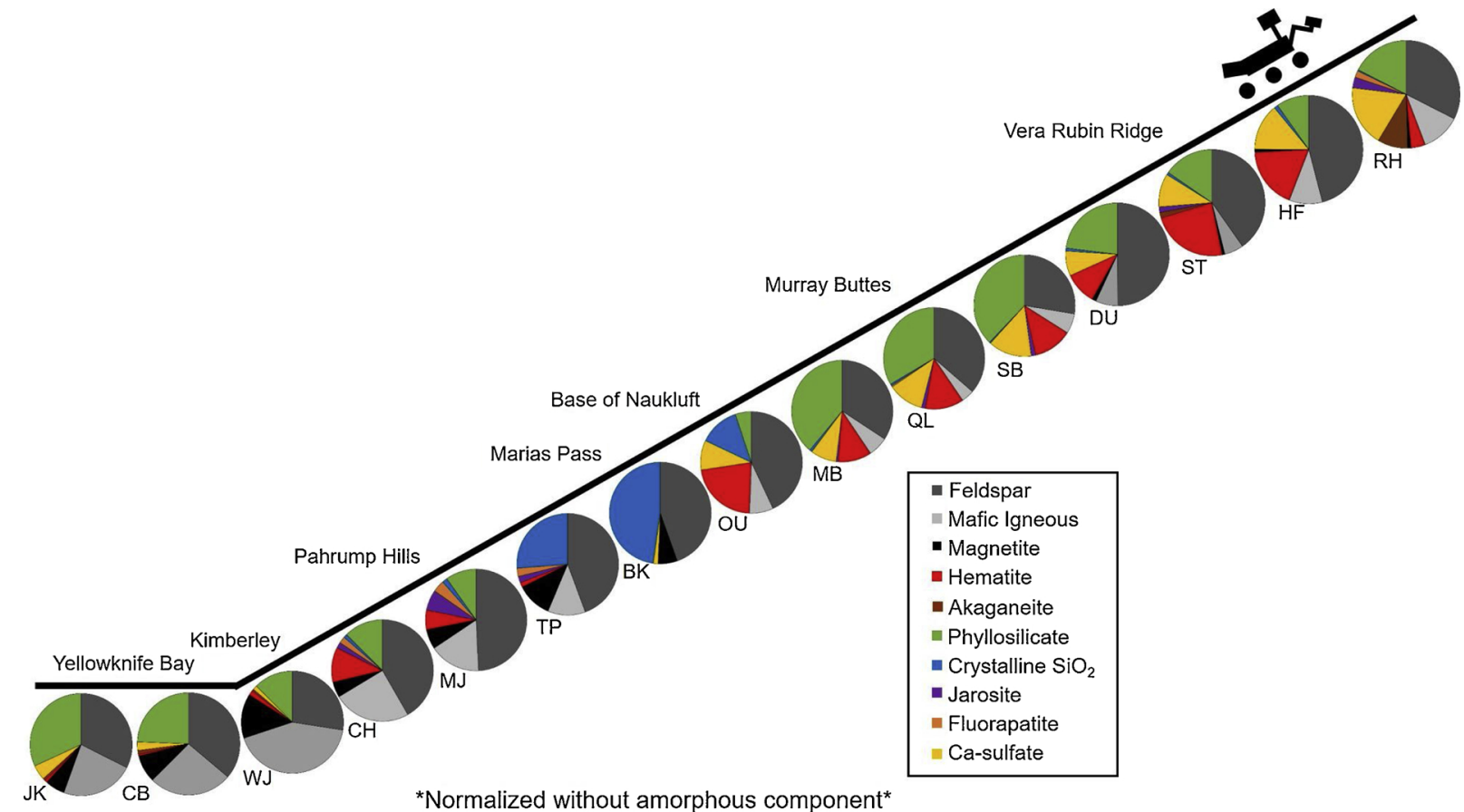

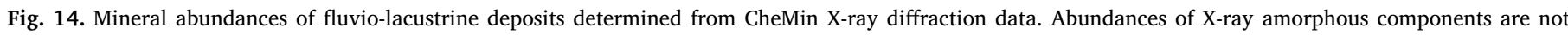

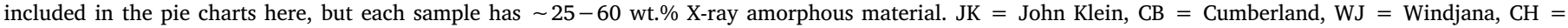

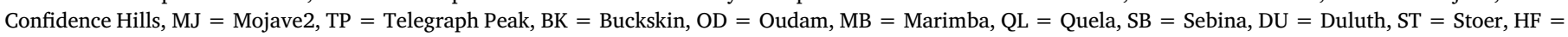
Highfield, RH = Rock Hall. Image credit: NASA/JPL-Caltech.

component suggests it is enriched in $\mathrm{SiO}_{2}$, consistent with abundant opaline silica. The halos are extensively depleted in $\mathrm{Mg}, \mathrm{Al}, \mathrm{Mn}, \mathrm{Fe}, \mathrm{Ni}$, and $\mathrm{Zn}$, consistent with a preferential loss of mafic phases as a result of aqueous alteration, and are enriched in Si and S (Table 12). The study of alteration halos by Curiosity was especially significant because the halos formed after the deposition and lithification of the Stimson formation, so they represent late-stage aqueous processes at Gale crater.

\section{Diverse igneous sediment sources in and around Gale crater}

CheMin has not analyzed parent igneous rocks, but the igneous minerals found in modern eolian sediments and ancient sedimentary rocks can provide some insight into the igneous history and source rocks near Gale crater. All samples analyzed by CheMin contain igneous minerals, and their variety suggests sediments were derived from both primitive and evolved igneous sources. The abundance of basaltic igneous minerals (i.e., plagioclase, pyroxene, and olivine) in modern and ancient eolian samples suggests mafic igneous sources for these sediments. Olivine-bearing units identified on the rim of Gale crater from orbital visible and near- to short-wave infrared reflectance spectral data collected by the Compact Reconnaissance Imaging Spectrometer for Mars (CRISM) on the Mars Reconnaissance Orbiter and/or dark mafic sedimentary units in Mount Sharp may be the source for the modern eolian sediments (Ehlmann and Buz, 2015; Achilles et al., 2017; Rudolph et al., 2019). The pyroxene and olivine compositions of the modern eolian sediments derived from refined unit-cell parameters show that olivine and pigeonite have similar molar $\mathrm{Mg} /(\mathrm{Mg}+\mathrm{Fe})$, whereas the augite is much more enriched in Mg (Achilles et al., 2017). This discrepancy can arise from either multiple mafic igneous sources, chemical zonation within a single igneous source, or partial 


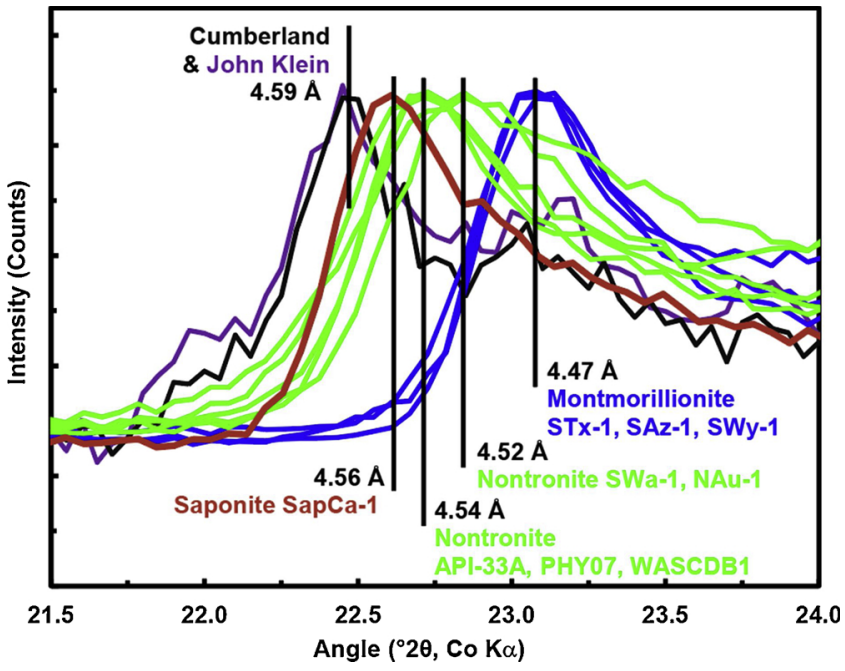

Fig. 15. Position of $(02 l)$ peaks in XRD patterns of the John Klein and Cumberland samples measured by CheMin on Mars and of different smectite minerals measured on the laboratory version of CheMin. Vertical lines denote peak maxima and values represent d-spacings. Adapted from Vaniman et al. (2014).

equilibration of a magma with a composition similar to that of the martian meteorite Nakhla (Achilles et al., 2017). However, pyroxene compositions are difficult to constrain from CheMin XRD data and these interpretations should not be considered conclusive. Furthermore, compositional zoning in crystals cannot be inferred from bulk XRD data because results from Rietveld refinements reflect mean values of crystal chemistry, so there are limitations to our interpretations of the igneous petrogenesis of the sediment sources.

Basaltic igneous minerals are found in many of the fluvio-lacustrine mudstone samples, a further indication that mafic igneous sources contributed to ancient sediments in Gale crater, but the mineralogy of two samples, in particular, suggests that considerably evolved igneous sources were present as well. The "Windjana" sample was drilled from reworked fluvial-eolian sediment in the Kimberley formation on the plains of Gale crater. Geochemical analyses of the Kimberley formation show it is enriched in $\mathrm{K}_{2} \mathrm{O}$ (up to 5.6 wt.\% from ChemCam; Le Deit et al., 2016), and mineralogical analysis of the "Windjana" sample demonstrates that it contains abundant sanidine $\left(\sim \mathrm{Or}_{95}\right)$, in addition to pyroxene, olivine, and magnetite (Treiman et al., 2016). The presence of sanidine indicates that "Windjana" was not sourced from a slowly cooled igneous rock because the ordered K-feldspars orthoclase and microcline form under those conditions. Treiman et al. (2016) speculate that the sanidine formed from potassic volcanic or metasomatic rocks and that the sediments in "Windjana" were derived from multiple igneous sources, because it is unlikely that sanidine and pigeonite are from the same protolith. They suggest that sanidine was sourced from a potassic trachyte or melatrachyte, whereas the pigeonite was from a basalt with a composition similar to the shergottite martian meteorites. This conclusion from CheMin data is consistent with the identification of at least two distinct geochemical sources (potassic and basaltic) of sediments from APXS and ChemCam data of all targets in the Bradbury group (Le Deit et al., 2016; Mangold et al., 2016; Edwards et al., 2017; Siebach et al., 2017; Bedford et al., 2019). Hydrothermal alteration of basalt by potassic fluids, however, can also produce sanidine (Morris et al., 2020), and the CheMin team is investigating the possibility that this process caused the formation of sanidine in Windjana (e.g., Ott et al., 2019).

The most silica-rich targets analyzed to date are in the Marias Pass area at the top of the Pahrump Hills member in the Murray formation, where some ChemCam analyses showed $>90 \mathrm{wt} . \% \mathrm{SiO}_{2}$ (Frydenvang et al., 2017) and up to 6 wt.\% $\mathrm{H}_{2} \mathrm{O}$ (Rapin et al., 2018). CheMin analysis of the "Buckskin" sample demonstrated that the lacustrine mudstone in this location contains abundant tridymite, plagioclase, sanidine, magnetite, cristobalite, and opaline silica (Morris et al., 2016). The detection of abundant tridymite was a surprise to the Science Team because Mars is generally a basaltic planet. This assemblage at "Buckskin" is most consistent with silicic volcanism, and tridymite on Earth is commonly found in rhyolites that experienced vapor-phase alteration or acidic hydrothermal alteration at temperatures up to $900{ }^{\circ} \mathrm{C}$ (Morris et al., 2016, and references therein). Tridymite formation may not require silicic volcanism; tridymite has been identified in mafic and intermediate volcanic rocks in which amorphous silica from acid-sulfate leaching was altered by high-temperature vapors or contact metamorphism (e.g., Getahun et al., 1996; Del Moro et al., 2011). However, the high concentration of tridymite and the absence of mafic silicates (e.g., pyroxene, olivine) suggest the sediments at Marias Pass were in fact derived from a silicic volcanic source.

The source of the silicic sediments remains enigmatic. Infrared spectroscopic measurements of the Gale crater rim do not reveal any silica-rich source areas. Anhydrous silica minerals would be difficult to detect in visible and near- to short-wave infrared reflectance spectra, but would be detectable in thermal-infrared emission spectra if the outcrop was sufficiently large (e.g., Smith and Bandfield, 2012). The source of the silicic sediments may have been completely denuded; it may be obscured by younger units; its spatial extent may be limited and therefore may not be detectable by remote sensing measurements; or it

Table 7

Abundances of minerals and amorphous component- (in wt.\%) for modern eolian sediment samples measured by CheMin. Uncertainties in parentheses are 1 $\sigma$, where the error is applied to the last significant digit(s). The symbol "-" indicates that phase is at or below the detection limit of CheMin.

\begin{tabular}{|c|c|c|c|c|c|c|}
\hline & \multicolumn{2}{|l|}{ Rocknest $^{1}$} & \multicolumn{2}{|l|}{ Gobabeb $^{1}$} & \multicolumn{2}{|c|}{ Ogunquit Beach ${ }^{2}$} \\
\hline & Crystalline & Xtal + Amor & Crystalline & Xtal + Amor & Crystalline & Xtal + Amor \\
\hline Plagioclase & $40.7(5)$ & $26.3(7)$ & $36.5(8)$ & $23.7(8)$ & $47.1(10)$ & $24.7(5)$ \\
\hline Pyroxene & $30.4(25)$ & 19.7(17) & $32.6(8)$ & $20.9(12)$ & $25.9(24)$ & $13.6(12)$ \\
\hline Olivine & $20.5(4)$ & $13.3(4)$ & $25.8(4)$ & $16.8(6)$ & $18.2(7)$ & $9.6(3)$ \\
\hline Quartz & $1.3(3)^{*}$ & $0.8(2)$ & $0.8(1)^{*}$ & $0.5(1)$ & $1.6(2)^{*}$ & $0.8(1)$ \\
\hline Magnetite & $2.5(5)$ & $1.8(3)$ & $2.1(2)$ & $1.4(2)$ & $2.5(3)$ & $1.3(2)$ \\
\hline Hematite & $1.4(3)^{*}$ & $0.9(2)$ & $0.9(1)^{*}$ & $0.6(2)$ & $2.3(3)$ & $1.2(2)$ \\
\hline Ilmenite & $1.3(5)$ & $0.9(3)$ & - & - & - & - \\
\hline Anhydrite & $1.6(1)^{*}$ & $1.0(1)$ & $1.3(1)^{*}$ & $0.8(1)$ & $2.3(3)$ & $1.2(2)$ \\
\hline Phyllosilicate ${ }^{\dagger}$ & - & - & - & - & - & $7.4(30)$ \\
\hline Amorphous & & $35(15)$ & & $35(15)$ & & $40(15)$ \\
\hline
\end{tabular}

\footnotetext{
1 From Achilles et al. (2017).

2 From Rampe et al. (2018).

* At the detection limit of the CheMin instrument.

$\dagger$ From contamination in CheMin funnel from previous sample (Sebina).
} 

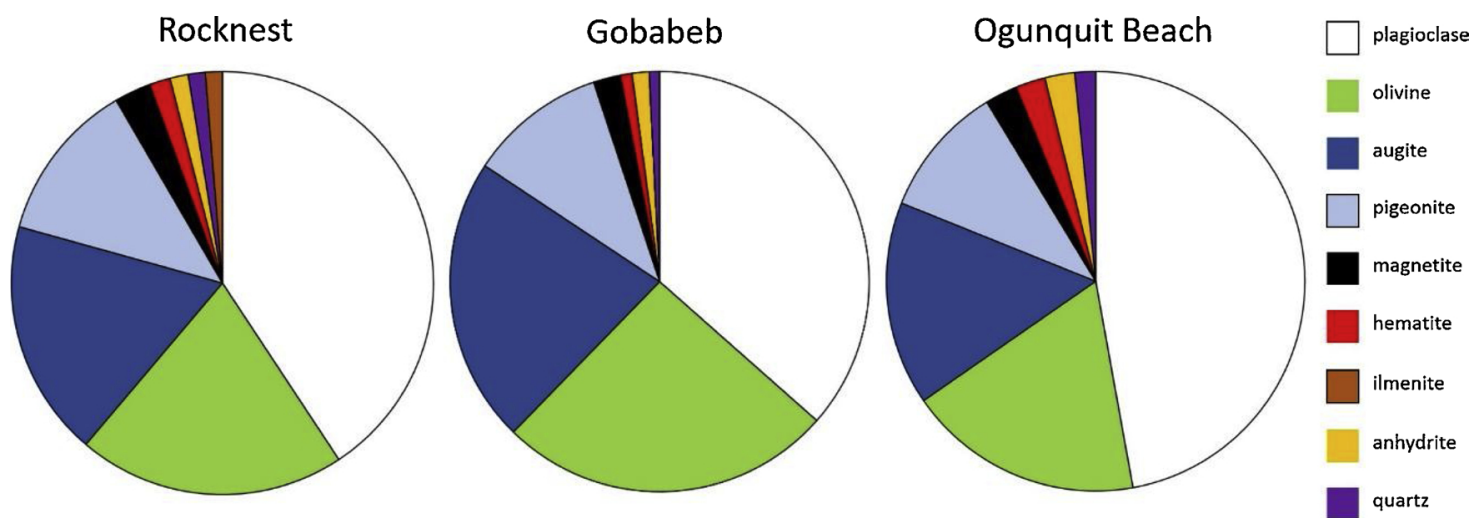

Fig. 16. Relative mineral abundances of eolian samples (renormalized without X-ray amorphous component). Abundances from Achilles et al. (2017) and Rampe et al. (2018).

may be in the mostly concealed central uplift peak of Gale crater. Although there is no known pathway to produce tridymite at the relatively low temperatures that these sediments may have experienced as a result of burial $\left(<80^{\circ} \mathrm{C}\right.$; Borlina et al., 2015), there is geochemical evidence for hydrothermal alteration in the vicinity of Marias Pass (e.g., elevated Ge in complex, late diagenetic veins in the Pahrump Hills member; Berger et al., 2017), and the possible role of hydrothermal fumarolic alteration in the formation of the mineral assemblage in Buckskin is being evaluated (Yen et al., 2020). Furthermore, gray hematite identified in the Oudam sample from Hartmann's Valley and the Highfield sample from Vera Rubin ridge commonly forms at elevated temperatures of $\sim 80-200{ }^{\circ} \mathrm{C}$ (Catling and Moore, 2003; Rampe et al., 2020).

\section{Modern eolian processes in Gale crater}

The mineralogy of active and inactive eolian deposits is remarkably similar (Achilles et al., 2017; Rampe et al., 2018). All eolian samples measured by CheMin are dominated by plagioclase, olivine, pyroxene, and X-ray amorphous materials. The primary difference between active and inactive eolian sediments is the composition of the X-ray amorphous material. The inactive deposits, represented by the "Rocknest" sample, contain martian dust. Martian dust compositions have been constrained by APXS based on observations of airfall dust on the rover's observation tray (Berger et al., 2016) and by ChemCam, because nearly all first laser shots of rocks and soils measure eolian dust (Lasue et al., 2018). APXS and ChemCam measurements indicate the dust is enriched in $\mathrm{SO}_{3}, \mathrm{Cl}$, and $\mathrm{Fe}$ relative to bulk soils. The X-ray amorphous component of "Rocknest" is also enriched in $\mathrm{SO}_{3}, \mathrm{Cl}$, and $\mathrm{Fe}$ relative to the bulk sample composition, suggesting dust contributes to the X-ray amorphous component in the inactive soils (Achilles et al., 2017). SAM evolved gas measurements of "Rocknest" show a greater low-temperature $\mathrm{H}_{2} \mathrm{O}$ release than active eolian samples, and ChemCam data demonstrate the fine-grained component of inactive soils is enriched in $\mathrm{H}$, consistent with more adsorbed water on dust particles (e.g., Leshin et al., 2013; Meslin et al., 2013).

Mineral segregation in the active Bagnold Dune Field has been recognized using CRISM orbital data, where barchanoidal dunes at the
Table 9

Calculated compositions for the X-ray amorphous component in modern eolian samples.

\begin{tabular}{llll}
\hline & Rocknest $^{1}$ & Gobabeb $^{1}$ & Ogunquit Beach $^{2}$ \\
\hline $\mathrm{SiO}_{2}$ & 34.58 & 49.53 & 45.60 \\
$\mathrm{TiO}_{2}$ & 2.12 & 2.12 & 2.15 \\
$\mathrm{Al}_{2} \mathrm{O}_{3}$ & 5.45 & 7.86 & 6.89 \\
$\mathrm{Cr}_{2} \mathrm{O}_{3}$ & 1.39 & 0.94 & 1.07 \\
$\mathrm{FeO}_{\mathrm{T}}$ & 23.27 & 19.82 & 22.33 \\
$\mathrm{MnO}$ & 1.20 & 0.89 & 0.83 \\
$\mathrm{MgO}$ & 4.05 & 0.00 & 2.60 \\
$\mathrm{CaO}$ & 4.45 & 3.06 & 5.07 \\
$\mathrm{Na} 2$ & 3.38 & 4.46 & 2.91 \\
$\mathrm{~K}_{2} \mathrm{O}$ & 1.39 & 1.18 & 1.37 \\
$\mathrm{P}_{2} \mathrm{O}_{5}$ & 2.70 & 1.91 & 1.76 \\
$\mathrm{SO}_{3}$ & 14.04 & 7.02 & 6.10 \\
$\mathrm{Cl}$ & 2.96 & 1.21 & 1.32 \\
\hline
\end{tabular}

${ }^{1}$ From Achilles et al. (2017).

${ }^{2}$ From Rampe et al. (2018).

upwind margin and crests of linear dunes have stronger olivine signatures and the stoss sides of barchanoidal dunes have stronger high-Ca pyroxene signatures (Seelos et al., 2014; Lapotre et al., 2017). Orbital data also suggest that olivine and plagioclase abundances are anticorrelated (Lapotre et al., 2017). In-situ mineralogical and geochemical measurements using CheMin, APXS, and ChemCam demonstrate that there are compositional differences in dunes and across the dune field that can be attributed to sediment sorting and/or distinct local sediment sources (Cousin et al., 2017b; Johnson et al., 2017a; Rampe et al., 2018; O'Connell-Cooper et al., 2018). CheMin measurements of a sample from a barchanoidal dune on the upwind margin during Phase 1 of the Bagnold Dune campaign (the "Gobabeb" sample from Namib Dune) and a sample from a sand patch near linear dunes downwind from Namib Dune during Phase 2 of the campaign (the "Ogunquit Beach" sample from the Mount Desert Island sand patch) show that the upwind margin contains more olivine and less plagioclase than the sands downwind. CRISM analyses of the sampling locations, however, show that the upwind margin contains more plagioclase and less olivine than the sands downwind (Rampe et al., 2018). This discrepancy is likely the

Table 8

Crystal chemistry of major igneous phases in modern eolian samples calculated from refined unit-cell parameters. Uncertainties in parentheses are $1 \sigma$.

\begin{tabular}{|c|c|c|c|c|}
\hline & Plagioclase & Augite & Pigeonite & Olivine \\
\hline Rocknest $^{1}$ & $\mathrm{An}_{49(4)}$ & $\mathrm{En}_{47(5)} \mathrm{Fs}_{17(5)} \mathrm{Wo}_{36(2)}$ & $\mathrm{En}_{48(4)} \mathrm{Fs}_{52(5)}$ & $\mathrm{Fo}_{57(2)}$ \\
\hline Gobabeb $^{1}$ & $\mathrm{An}_{63(5)}$ & $\mathrm{En}_{45(4)} \mathrm{Fs}_{19(5)} \mathrm{Wo}_{37(2)}$ & $\mathrm{En}_{48(6)} \mathrm{Fs}_{50(9)} \mathrm{Wo}_{3(4)}$ & $\mathrm{Fo}_{54(2)}$ \\
\hline Ogunquit Beach ${ }^{2}$ & $\mathrm{An}_{48(5)}$ & $\mathrm{En}_{64(10)} \mathrm{Fs}_{4(12)} \mathrm{Wo}_{33(4)}$ & $\mathrm{En}_{66(11)} \mathrm{Fs}_{32(15)} \mathrm{Wo}_{8(6)}$ & $\mathrm{Fo}_{60(3)}$ \\
\hline
\end{tabular}

\footnotetext{
1 From Achilles et al. (2017).
}

2 From Rampe et al. (2018). 
Table 10

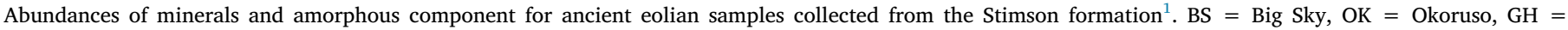

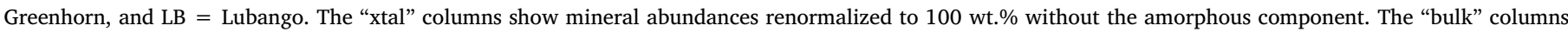

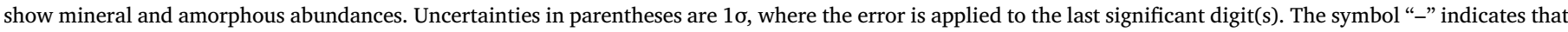
phase is at or below the detection limit of CheMin.

\begin{tabular}{|c|c|c|c|c|c|c|c|c|}
\hline & BS $\mathrm{xtal}^{2}$ & BS bulk & GH xtal & GH bulk & OK xtal & OK bulk & LB xtal & LB bulk \\
\hline Plagioclase & $45.6(22)$ & $36.5(18)$ & $42.1(24)$ & $14.7(8)$ & $41.9(26)$ & $27.2(17)$ & $43.2(24)$ & $11.7(6)$ \\
\hline K-feldspar & $1.4(8)$ & $1.1(6)$ & - & - & $2.9(10)$ & $1.9(7)$ & - & - \\
\hline Pigeonite & $21.2(18)$ & $17.0(14)$ & $4.7(14)$ & $1.6(5)$ & $20.8(20)$ & $13.5(13)$ & $5.9(14)$ & $1.6(4)$ \\
\hline Orthopyroxene & $10.5(22)$ & $8.4(18)$ & $7.6(20)$ & $2.7(7)$ & $11.0(22)$ & $7.2(14)$ & $10.4(21)$ & $2.8(5)$ \\
\hline Magnetite & $12.9(8)$ & $10.3(6)$ & $17.3(10)$ & $6.1(3)$ & $17.3(10)$ & $11.2(7)$ & 11.1(9) & $3.0(2)$ \\
\hline Hematite & $3.8(6)$ & $3.0(5)$ & $6.0(8)$ & $2.1(3)$ & $1.1(6)$ & $0.7(4)$ & $2.3(6)$ & $0.6(2)$ \\
\hline Quartz & $1.7(4)$ & $1.4(3)$ & $2.2(6)$ & $0.8(2)$ & $1.4(4)$ & $0.9(3)$ & $3.5(7)$ & $0.9(2)$ \\
\hline Anhydrite & $1.5(4)$ & $1.2(3)$ & $16.1(10)$ & $5.6(3)$ & $0.8(6)$ & $0.5(4)$ & $12.3(9)$ & $3.3(2)$ \\
\hline Bassanite & - & - & $4.0(10)$ & $1.4(3)$ & $1.2(6)$ & $0.8(4)$ & $9.0(10)$ & $2.4(3)$ \\
\hline Gypsum & - & - & - & - & - & - & $2.3(7)$ & $0.6(2)$ \\
\hline Fluorapatite & $1.4(6)$ & $1.1(5)$ & - & - & $1.6(6)$ & $1.0(4)$ & - & - \\
\hline Amorphous & & $20(10)$ & & $65(20)$ & & $35(15)$ & & $73(20)$ \\
\hline
\end{tabular}

1 From Yen et al. (2017a).

${ }^{2}$ Abundances in BS do not include the $1.4 \mathrm{wt} . \%$ tridymite contamination from the Buckskin sample.

result of the scooping location and the sediment size analyzed by CheMin. The "Gobabeb" sample from the Namib Dune on the upwind margin was collected from a ripple crest, and APXS and ChemCam data demonstrate ripple crests show higher concentrations of olivine (Cousin et al., 2017b; Johnson et al., 2017a; O'Connell-Cooper et al., 2017). The "Ogunquit Beach" sample collected downwind was from a ripple trough, in which felsic grains are concentrated. CheMin also analyzed the $<150 \mu \mathrm{m}$ grain size, so the mineralogy of the coarser sand size fraction was not captured by CheMin. Furthermore, CheMin did not observe any differences in relative abundances of olivine and high-Ca pyroxene as is suggested from olivine and high-Ca pyroxene parameter maps from CRISM data (Seelos et al., 2014). This observation suggests that segregation between olivine and high-Ca pyroxene occurs in the $>150 \mu \mathrm{m}$ size fraction.

Orbital spectral data and in-situ compositional data from Curiosity can be used in a complementary fashion to construct a more complete picture of modern eolian processes and sediment segregation in Gale crater. Bulk mineralogy from CRISM and the concentration of olivine with respect to plagioclase downwind indicates that fine-grained olivine is preferentially transported and concentrated downwind (Rampe et al., 2018). The stronger olivine spectral signatures compared to highCa pyroxene in the upwind margin suggests that there is a coarsegrained olivine lag in the barchanoidal dunes. The variations in olivine and plagioclase abundances from samples measured by CheMin as well as spectral and chemical variations observed in place by ChemCam and APXS suggest that there are significant mineralogical variations between ripple troughs and ripple crests. The minor and major mineral crystal chemistry derived from CheMin analyses also suggests that the local bedrock has been eroded and contributes to eolian sediments. Contributions of local bedrock were also positively identified in the "Rocknest" soil by ChemCam (Meslin et al., 2013). The presence of minor to trace amounts of hematite, Ca-sulfate, and quartz in the eolian samples collected from the Bagnold Dune Field are likely from the underlying Murray formation, which contains abundant hematite and
Table 12

Calculated compositions for the X-ray amorphous component in ancient eolian samples ${ }^{1}$.

\begin{tabular}{lllll}
\hline & Big Sky & Greenhorn & Okoruso & Lubango \\
\hline $\mathrm{SiO}_{2}$ & 24.13 & 63.53 & 43.91 & 68.00 \\
$\mathrm{TiO}_{2}$ & 6.59 & 1.54 & 3.65 & 1.57 \\
$\mathrm{Al}_{2} \mathrm{O}_{3}$ & 0.12 & 0.00 & 3.62 & 0.00 \\
$\mathrm{Cr}_{2} \mathrm{O}_{3}$ & 3.36 & 0.69 & 1.59 & 0.41 \\
$\mathrm{FeO}_{\mathrm{T}}$ & 17.48 & 10.16 & 16.67 & 4.79 \\
$\mathrm{MnO}$ & 2.64 & 0.21 & 1.52 & 0.13 \\
$\mathrm{MgO}$ & 14.68 & 1.46 & 14.54 & 0.87 \\
$\mathrm{CaO}$ & 0.00 & 5.47 & 7.94 & 6.52 \\
$\mathrm{Na} 2 \mathrm{O}$ & 6.03 & 2.08 & 3.24 & 1.19 \\
$\mathrm{~K}_{2} \mathrm{O}$ & 1.40 & 0.46 & 0.00 & 0.44 \\
$\mathrm{P}_{2} \mathrm{O}_{5}$ & 1.69 & 1.77 & 0.97 & 1.87 \\
$\mathrm{SO}_{3}$ & 17.08 & 11.93 & 0.41 & 13.77 \\
$\mathrm{Cl}$ & 4.81 & 0.70 & 1.94 & 0.45 \\
\hline
\end{tabular}

${ }^{1}$ From Morrison et al. (2018b).

Ca-sulfate, especially, above the Pahrump Hills member (e.g., Bristow et al., 2018). The difference in plagioclase crystal chemistry between the "Gobabeb" and "Ogunquit Beach" samples $\left(\mathrm{An}_{63(5)}\right.$ and $\mathrm{An}_{48(5)}$, respectively) could result from different plagioclase compositions of the underlying rocks or from different sediment sources for the Bagnold Dune Field.

\section{Ancient aqueous conditions in Gale crater}

Evidence for a long-lived lake or lake system in Gale crater is compelling. The physical characteristics and chemistry of the lake (e.g., its depth, salinity, $\mathrm{pH}$, Eh) can be derived from the sedimentary features and the mineralogy and geochemistry of the lithified sediments. The aqueous history of Gale crater sediments investigated to date can be divided into three temporally distinct processes: Deposition (processes which occur at the time the sediment was deposited), authigenesis/

Table 11

Crystal chemistry of major igneous phases in ancient eolian samples calculated from refined unit-cell parameters ${ }^{1}$. Uncertainties in parentheses are $1 \sigma$.

\begin{tabular}{llll}
\hline & Plagioclase & Orthopyroxene & \multicolumn{1}{c}{ Pigeonite } \\
\hline Big Sky & $\mathrm{An}_{52(5)}$ & $\left.\mathrm{Mg}_{0.69(7)} \mathrm{Fe}_{1.31(7)}\right) \mathrm{Si}_{2} \mathrm{O}_{6}$ & $\left.\mathrm{Mg}_{1.44(7)} \mathrm{Fe}_{0.39(9)} \mathrm{Ca}_{0.17(4)}\right)$ \\
Greenhorn & $\mathrm{An}_{20(6)}$ & $\mathrm{Mg}_{0.80(8)} \mathrm{Fe}_{1.16(9)} \mathrm{Ca}_{0.04(4)} \mathrm{Si}_{2} \mathrm{O}_{6}$ & $*$ \\
Okoruso & $\mathrm{An}_{39(5)}$ & $\mathrm{Mg}_{0.86(20)} \mathrm{Fe}_{1.14(20)} \mathrm{S}_{2} \mathrm{O}_{6}$ & $\mathrm{Mg}_{1.39(7)} \mathrm{Fe}_{0.48} \mathrm{Ca}_{0.13(5)} \mathrm{Si}_{2} \mathrm{O}_{6}$ \\
Lubango & $\mathrm{An}_{30(8)}$ & $\mathrm{Mg}_{0.81(10)} \mathrm{Fe}_{1.19(1)} \mathrm{Si}_{2} \mathrm{O}_{6}$ & $\mathrm{Mg}_{1.54(17)} \mathrm{Fe}_{0.18(17)} \mathrm{Ca}_{0.28(6)} \mathrm{Si}_{2} \mathrm{O}_{6}$ \\
\hline
\end{tabular}

\footnotetext{
${ }^{1}$ From Morrison et al. (2018b).
}

* Unit-cell parameters were not refined because of insufficient abundance. 
early diagenesis (processes which occur concurrently with deposition or shortly thereafter, prior to lithification), and late stage diagenesis (processes which occur after lithification, up to the present day). These processes are exquisitely preserved in the Sheepbed mudstone member of the Yellowknife Bay formation where the first two drill samples ("John Klein" and "Cumberland") were collected.

The Sheepbed mudstone is interpreted as a shallow lacustrine deposit (Grotzinger et al., 2014). The mudstone exhibits abundant evidence for early diagenesis, including erosionally resistant ("raised") ridges enriched in magnesium (Léveillé et al., 2014), which are interpreted as lithified subaqueous shrinkage cracks (Siebach et al., 2014), and a variety of spheroidal Ca-sulfate-filled voids and cemented concretions, suggesting that groundwater influenced the sediment before it was lithified (Stack et al., 2014). Light-toned Ca-sulfate bearing veins observed in Yellowknife Bay (e.g., Nachon et al., 2014) and throughout nearly the entirety of Curiosity's traverse (e.g., Grotzinger et al., 2015; Nachon et al., 2017; Kronyak et al., 2019) are evidence for late-stage diagenesis resulting from fluids moving through fractures in the rocks. The observation of hydraulic fracturing in the Sheepbed unit suggests that these sediments were buried to a depth of at least $1000 \mathrm{~m}$ (Schieber et al., 2017).

The mineralogy of the "John Klein" and "Cumberland" samples (Vaniman et al., 2014) can be compared with the mineralogy of its presumed original source rock at the crater rim (olivine basalt) to evaluate depositional, authigenic, and diagenetic processes in the Sheepbed mudstone. For example, using the mineralogy of the "Rocknest" sand shadow as a proxy for the source rock, the basaltic minerals plagioclase and pyroxene are present in similar quantities in the Sheepbed mudstone, but olivine is absent. Instead, the mudstone contains a significant quantity of the clay mineral Fe-saponite and excesses of magnetite. Except for late-stage Ca-sulfate bearing veins, the mudstone has retained the same elemental ratios as its presumed igneous source minerals, i.e., these inferred changes in mineralogy would have occurred under isochemical conditions (McLennan et al., 2014). A process called "saponitization" would have led to the observed mineral assemblage, in which olivine and X-ray amorphous material reacted with water, close to the time of deposition, to yield an Fe-rich clay mineral (e.g., Fe-rich saponite; Treiman et al., 2014) plus magnetite and possibly hydrogen (Vaniman et al., 2014; Grotzinger et al., 2014; Bridges et al., 2015; Bristow et al., 2015; Tosca et al., 2018). Geochemical modeling indicates that pore waters hosting such mineral reactions would be driven to neutral to alkaline $\mathrm{pH}$ (Bristow et al., 2015, 2017; Tosca et al., 2018), a conclusion supported by the hypothesized intercalation of $\mathrm{Mg}$-hydroxy interlayers in smectite clay of the Cumberland sample (Vaniman et al., 2014). Such an authigenic mineral assemblage also requires that pore waters were poorly oxidizing to anoxic (Bristow et al., 2015, 2017; Hurowitz et al., 2017). Another key observation is the relative absence of enrichments in chlorides, sulfates, and carbonates in the lacustrine mudstone matrix in Yellowknife Bay, as shown by mineralogy and bulk geochemical measurements (McLennan et al., 2014; Grotzinger et al., 2014; Vaniman et al., 2014), demonstrating that pore waters were generally free of dissolved salts.

Taken together, the sedimentological, mineralogical, and geochemical data suggest a relatively fresh water lake with circumneutral $\mathrm{pH}$ existed during the deposition of Yellowknife Bay sediments $\sim 3.7 \mathrm{Ga}$ ago. The kinetics of olivine alteration suggest the presence of a benign aqueous environment for thousands to hundreds of thousands of years (Bristow et al., 2015). Moreover, the mediated oxidation of Fe(II) in olivine to Fe(III) in magnetite, and perhaps smectite, would have provided a potential chemolithoautotrophic energy source for organisms (Vaniman et al., 2014; Grotzinger et al., 2014; Bristow et al., 2015), and SAM and APXS detected the necessary elements for life (i.e., C, H, N, O, P, and S; McLennan et al., 2014; Ming et al., 2014). Thus, the deposits at Yellowknife Bay represent an important milestone achieved in MSL's prime mission, where an ancient habitable martian environment was first definitively established. Subsequent investigations by Curiosity have further broadened our knowledge of the history of habitable environments at Gale crater and are discussed in more detail in a the following section of this paper.

As is common in long-lived lake systems on Earth, aqueous conditions and the sediment sources of the lakes occupying Gale crater changed through time. This evolution is reflected by changes in the primary and secondary phases documented in the fluvio-lacustrine samples along Curiosity's route (e.g., Fig. 14). Note that most units Curiosity has drilled that are discussed here are stratigraphically below the hematite-, clay-, and sulfate-bearing units identified from orbit and do not present a clear orbital spectral signature for these secondary phases, demonstrating the importance of in-situ mineralogical measurements for characterizing ancient aqueous environments.

CheMin data reveal common occurrence of phyllosilicates in most fluvio-lacustrine samples (Vaniman et al., 2014; Rampe et al., 2017; Bristow et al., 2018). The phyllosilicates are generally consistent with collapsed smectite, but the character of the smectite changes going up section (i.e., going forward in time). At the base of the section in the "John Klein" and "Cumberland" samples, a trioctahedral Fe-smectite occurs (containing $\mathrm{Mg}$ and $\mathrm{Fe}(\mathrm{II})$ in its octahedral sites) (Vaniman et al., 2014; Treiman et al., 2014; Bristow et al., 2015). Higher in the section, mixed trioctahedral-dioctahedral smectites occur [Mg and Fe(II) are replaced by $\mathrm{Al}$ and $\mathrm{Fe}(\mathrm{III})]$, resembling montmorillonite and/or nontronite; Bristow et al., 2018). On Earth, dioctahedral smectite often forms from near-surface oxidative weathering, so the change in smectite structure observed over $100 \mathrm{~s}$ of $\mathrm{m}$ of stratigraphy suggests a gradual change in the weathering environment. The identification of Fepyrophyllite in some samples may point toward localized hydrothermal processes (Rampe et al., 2020).

Other secondary minerals also suggest an increase in the degree of oxidation and chemical weathering intensity experienced by lake sediments over time (Bristow et al., 2018; Mangold et al., 2019). For example, hematite is the prevalent Fe-oxide mineral in samples from the Hartmann's Valley, Karasburg, Sutton Island, Blunts Point, and Pettegrove Point members (samples "Oudam," "Marimba," "Quela," "Sebina," "Duluth," and "Stoer"), whereas magnetite is more common in samples drilled near the base of the section in the Sheepbed and Pahrump Hills members (samples "John Klein," "Cumberland," "Telegraph Peak," and "Buckskin"), suggesting increasingly oxidative conditions over time (Bristow et al., 2018). This finding is consistent with the results from the ChemCam and Mastcam reflectance spectra acquired along the traverse (Johnson et al., 2016, 2017b,c; Wellington et al., 2017a, b), which exhibit a shift to variable but pervasively ferric spectral features through the upper portion of the Murray formation. The Ca-sulfate minerals gypsum, bassanite, and anhydrite are also more abundant higher in the Murray formation sedimentary matrix (Bristow et al., 2018; Vaniman et al., 2018), and most diagenetic Ca-sulfate veins show a water content consistent with bassanite from ChemCam LIBS analyses, interpreted as a byproduct of gypsum dehydration (Rapin et al., 2016). A 150 m interval stratigraphically below the "Duluth" target in the Blunts Point member showed sporadic concentrations of Mg-sulfate and Ca-sulfate (26-36 wt.\% and 30-50 wt.\% of the bulk rock, respectively, in some locations) from ChemCam data (Rapin et al., 2019). These sulfate-rich strata may signify episodic evaporation and formation of brines. Unfortunately, Curiosity did not drill in this interval because of the anomaly with the drill feed so we did not analyze these rocks with CheMin and do not know the bulk mineral assemblage. These mineralogical changes in the bedrock suggest that the lake waters in Gale crater became more saline and oxidizing over time, or that later episodes of oxidizing, saline groundwater preferentially altered sediments higher in the stratigraphic section.

One hypothesis put forth to explain the changes in Fe-oxide mineralogy in the stratigraphy proposes that the lake present in ancient Gale crater was redox-stratified (Hurowitz et al., 2017). In this model (Fig. 17), shallow lake waters would have been oxidized by ultraviolet 
(UV) photolysis and by the exposure of surface waters to photochemically generated atmospheric $\mathrm{O}_{2}$. Deeper lake waters would have remained relatively anoxic as a result of the attenuation of UV light in the water column and decoupling from atmospheric $\mathrm{O}_{2}$. Overland flow from rivers and streams would have delivered clastic sediments to the lakes, including basaltic and silicic igneous minerals and, perhaps, phyllosilicates. Groundwater would have transported dissolved solutes, including $\mathrm{Fe}(\mathrm{II})_{(\mathrm{aq})}$, to the lakes. Groundwater flow into shallow, oxidizing lake waters would have resulted in the precipitation of hematite, and groundwater flow into deep, anoxic lake waters would have resulted in the precipitation of magnetite. Relatively high concentrations of the redox sensitive element Mn are found at the base of the Pahrump Hills member, in particular, and coincide with abundant hematite, suggesting some of the shallow lake waters were extremely oxidizing.

A second hypothesis to explain the changes in Fe-oxide mineralogy in the stratigraphy is that hematite formed via diagenetic oxidation of magnetite (Rampe et al., 2017). In this scenario, magnetite would have formed under alkaline, relatively anoxic conditions, either in the lake sediments prior to lithification or in the sediment source region, and acidic and/or oxidizing diagenetic fluids would have caused the alteration of magnetite to form hematite. Acid-sulfate alteration occurred in some of the samples drilled from the Murray formation, evidenced by the presence of minor to trace amounts of jarosite, which forms under a pH range of $\sim 2$ to 4 (e.g., Driscoll and Leinz, 2005). The trace element geochemistry of the Pahrump Hills member of the Murray formation also suggests that low $\mathrm{pH}$ diagenetic fluids moved through these sediments. Low abundances of $\mathrm{Ni}$ and $\mathrm{Zn}$ were measured at the top of the Pahrump Hills member in Marias Pass. Concentrations of these elements increased down-section and were highly enriched relative to average Mars crust at the base of the Pahrump Hills section (Fig. 18). Acid-sulfate fluids moving down-section from Marias Pass may have mobilized $\mathrm{Ni}$ and $\mathrm{Zn}$, and these elements may have precipitated as discrete sulfates or as adsorbed species onto phyllosilicates and/or nanophase Fe-oxides as the fluids were neutralized down-section (Fig. 19; Rampe et al., 2017). Leaching by acid-sulfate fluids may also explain the opaline silica detected by CheMin and the coordinated strong enrichments in $\mathrm{H}$ and Si observed by ChemCam (Rapin et al., 2018) at the top of the Pahrump Hills member (in the "Telegraph Peak" and "Buckskin" samples) and the Hartmann's Valley member (in the "Oudam" sample). In the presence of acidic fluids, Si is relatively resistant to mobilization compared to other common elements (e.g., $\mathrm{Mg}$, $\mathrm{Ca}, \mathrm{Na}, \mathrm{K}, \mathrm{Al}$ ) so that it becomes passively enriched as other elements are transported from the system (e.g., Ming et al., 2008; Squyres et al., 2008). The source of the acid-sulfate fluids is unknown, but could be from oxidation of Fe-sulfides, dissolution of Fe-sulfates in groundwater, or interaction between magmatic volatiles and groundwater (Rampe et al., 2017). Fe-sulfides have not been detected with confidence above detection limits by CheMin, but SAM evolved gas data from the "Rocknest" eolian deposit indicate the presence of trace sulfides (McAdam et al., 2014).

The abundance of diagenetic features in the Yellowknife Bay member of the Bradbury formation and the Murray and Stimson formations extends morphologically to fluidized pipes (Rubin et al., 2017) and decimeter-size concretions (Wiens et al., 2017) which, along with diagenetic chemistry and mineralogy, indicates a rich history of groundwater in Gale crater. Differences in the geochemistry of some of

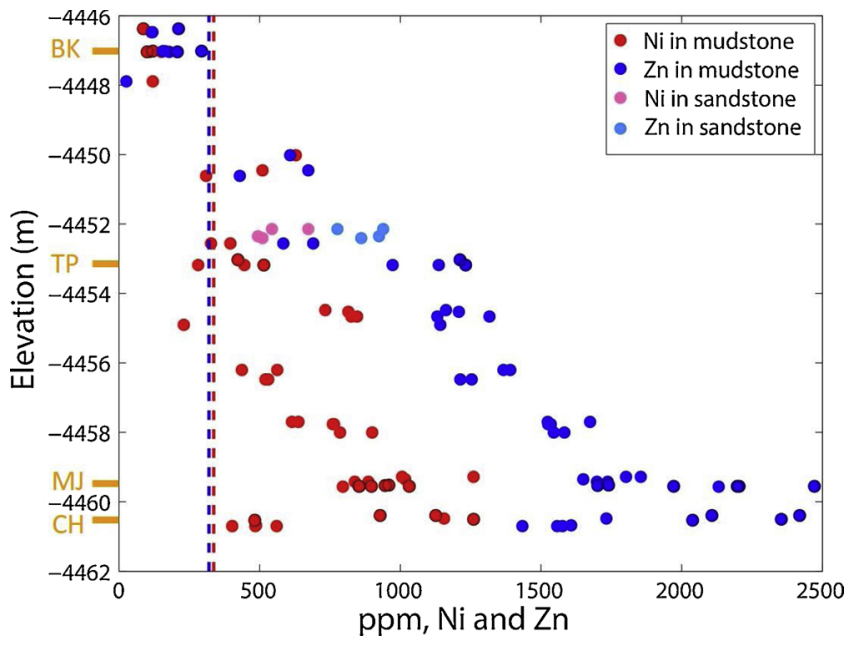

Fig. 18. $\mathrm{Ni}$ (in red) and $\mathrm{Zn}$ (in blue) abundances vs. elevation from APXS measurements of brushed (points with dark outlines) and unbrushed targets in the Pahrump Hills member. Elevations of the four samples drilled from the Pahrump Hills member are denoted in orange. Pink and light blue points represent $\mathrm{Ni}$ and $\mathrm{Zn}$ abundances, respectively, collected from a sandstone interval. All other points were measured from mudstone targets. Red and blue vertical lines represent average Mars crustal compositions of $\mathrm{Ni}$ and $\mathrm{Zn}$, respectively (Taylor and McLennan, 2009). Yellow markers on the y-axis represent drill locations, where $\mathrm{CH}=$ Confidence Hills, $\mathrm{MJ}=$ Mojave2, $\mathrm{TP}=$ Telegraph Peak, and BK = Buckskin. Adapted from Rampe et al. (2017) (For interpretation of the references to colour in this figure legend, the reader is referred to the web version of this article.).

these features suggest groundwater had variable compositions. For example, the raised ridges at the base of the stratigraphic section in Yellowknife Bay and dendritic aggregates at the base of the Pahrump Hills member (Fig. 20A) are enriched in Mg, suggesting that early-stage Mg-rich fluids, perhaps from the alteration of the abundant mafic minerals in that portion of the section, moved through the sediments before they lithified (Léveillé et al., 2014; Nachon et al., 2017). The apparent precipitation of Mn oxides from groundwater in the Bradbury group and the Murray formation suggests that fluids were strongly oxidizing in some locations (Lanza et al., 2014, 2016; Gasda et al., 2019).

Pervasive Ca-sulfate veins suggest that the late-stage post-lithification diagenetic fluids that moved through the fractured bedrock were enriched in $\mathrm{CaO}$ and $\mathrm{SO}_{3}$, and also fluorine in some locations (e.g., Nachon et al., 2014, 2017; Forni et al., 2015, 2016; Rapin et al., 2016). A detailed investigation of the morphology and composition of a complex suite of veins in the Pahrump Hills demonstrates three separate post-depositional fluid episodes each with a distinct fluid composition (Kronyak et al., 2019). Dissolution of sulfate-rich horizons may have led to the nearly pure Ca-sulfate veins seen throughout the Gale stratigraphy (Schwenzer et al., 2016). Millimeter-scale lenticular crystal molds whose morphology is reminiscent of gypsum (Fig. 20B) suggest that, in some locations, Ca-sulfate precipitated from early diagenetic fluids at the sediment-water or sediment-air interface (Kah et al., 2015a, b, 2018), but the absence of Ca-sulfate minerals from CheMin analysis of the "Mojave2" sample drilled from a crystal-mold-

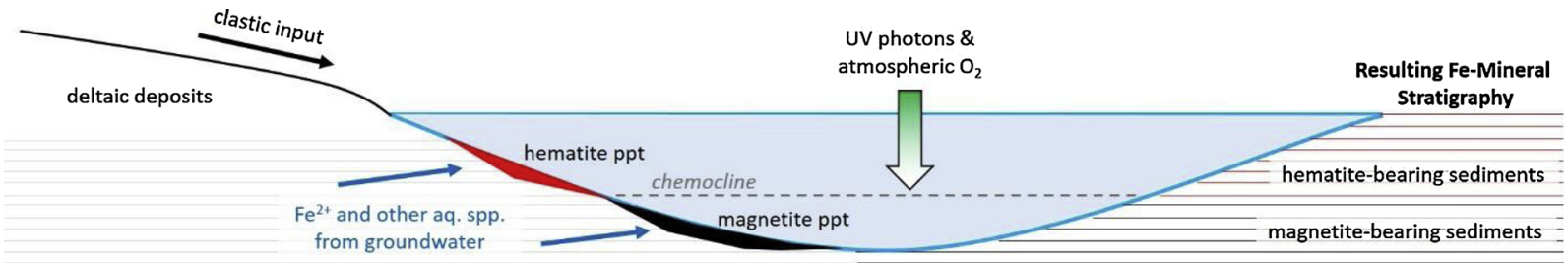

Fig. 17. Redox-stratified lake model, adapted from Hurowitz et al. (2017). 


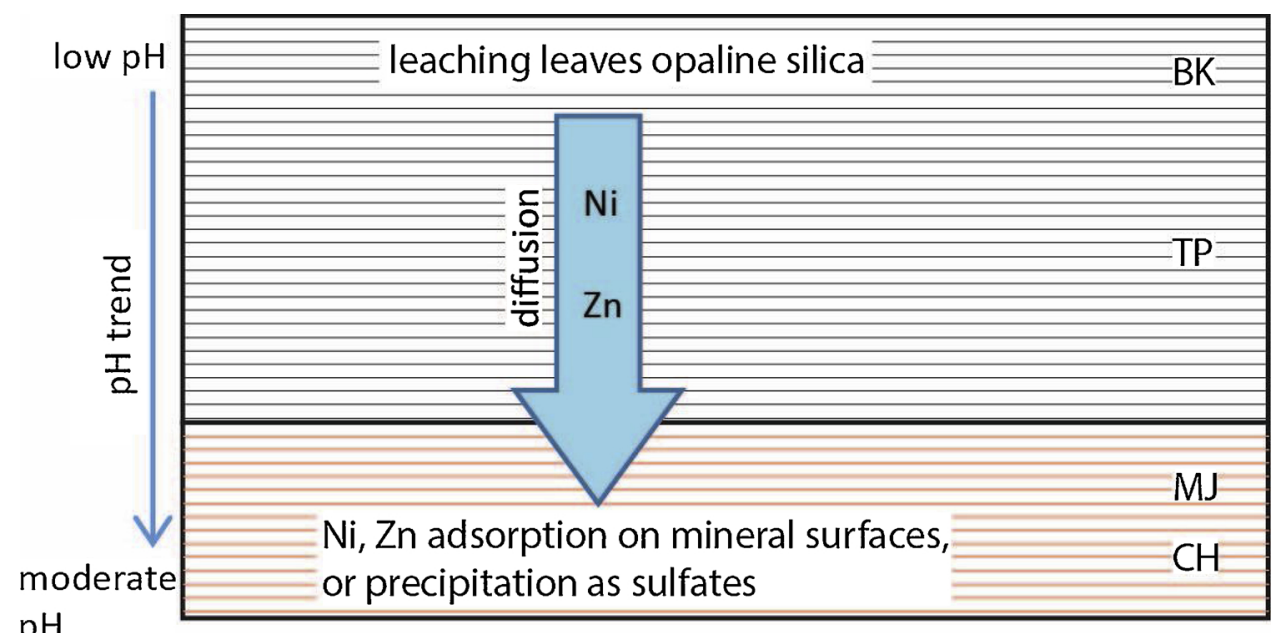

$\mathrm{pH}$

Fig. 19. Diagenetic alteration model to explain the mineralogy and geochemistry of the Pahrump Hills member, adapted from Rampe et al. (2017). $\mathrm{CH}=\mathrm{Confidence}$ Hills, MJ = Mojave2, $\mathrm{TP}=$ Telegraph Peak, $\mathrm{BK}=$ Buckskin.

rich mudstone indicates the Ca-sulfate was dissolved by later diagenetic fluids (Rampe et al., 2017; Kah et al., 2018).

Early diagenesis in the Stimson formation and the formation of magnetite cement likely at the expense of olivine is consistent with leaching from near-neutral fluids (Yen et al., 2017; Hausrath et al., 2018). The mineralogy and geochemistry of the fracture-associated halos suggest multiple fluid episodes at depth were associated with latestage diagenesis of the Stimson and Murray formations (Yen et al., 2017; Hausrath et al., 2018). Acidic, sulfate-rich diagenetic fluids may have caused the initial leaching of $\mathrm{Mg}, \mathrm{Al}, \mathrm{Mn}, \mathrm{Fe}, \mathrm{Ni}$, and $\mathrm{Zn}$, the preferential dissolution of pyroxene, and the abundance of Ca-sulfate and amorphous silica (Yen et al., 2017; Hausrath et al., 2018), while later alkaline fluids could have caused the observed addition of Si and precipitation of trace carbonate detected by SAM (Yen et al., 2017). The mobilization of Ni, Zn, and Mn seen in the Pahrump Hills section may be related to leaching observed in the Stimson formation.

In cases where visual evidence of a secondary mineral phase is present (e.g., the concretions in the Yellowknife Bay formation; Stack et al., 2014, and in the Murray formation; Sun et al., 2019), it is possible to determine whether they are authigenic, early or late-stage diagenetic. However, if the mineral occurs in the matrix of the sedimentary rock, it can be difficult to determine which minerals formed in the lake waters and which formed from groundwater, but K-Ar age-dating of jarosite in the Mojave2 sample near the base of the Pahrump Hills member has put one constraint on diagenetic processes in Gale crater.
SAM data indicate that the jarosite in Mojave2 formed $2.12 \pm 0.36 \mathrm{Ga}$ ago (Martin et al., 2017). This astounding result suggests groundwater was present in Gale crater at least 1.5 billion years after the rivers and lakes in Gale crater deposited the sediments of the Bradbury group and Murray formation. Although the presence of liquid water on the surface and near-subsurface may have been intermittent, a 1.5-billion-year history of liquid water at Gale crater has important implications for habitability and the potential for the existence of life on Mars.

The absence of certain secondary minerals can also help constrain ancient aqueous environments and diagenesis in Gale crater. Minerals like zeolites commonly precipitate from alkaline fluids, and specific zeolite minerals can be used to identify formation environments (e.g., closed alkaline, saline lakes, burial diagenetic deposits, and hydrothermal deposits; e.g., Ming and Mumpton, 1989). The absence of zeolites in Gale crater indicates the lake waters were not sufficiently alkaline and did not have high concentrations of $\mathrm{Si}$ and $\mathrm{Al}$ in solution. In basin environments on Earth, smectite in buried sediments commonly alters to illite, chlorite, or a mixed-layer phase (e.g., corrensite) through burial diagenesis (e.g., Denoyer de Segonzac, 1970). The abundance of smectite, but the absence of chlorite in the mudstones drilled by Curiosity demonstrates sediments in Gale crater did not experience pressures and temperatures associated with burial $>2 \mathrm{~km}$ (Borlina et al., 2015). The presence of amorphous silica, but the absence of abundant quartz further demonstrates that groundwater was present intermittently (Tosca and Knoll, 2009).

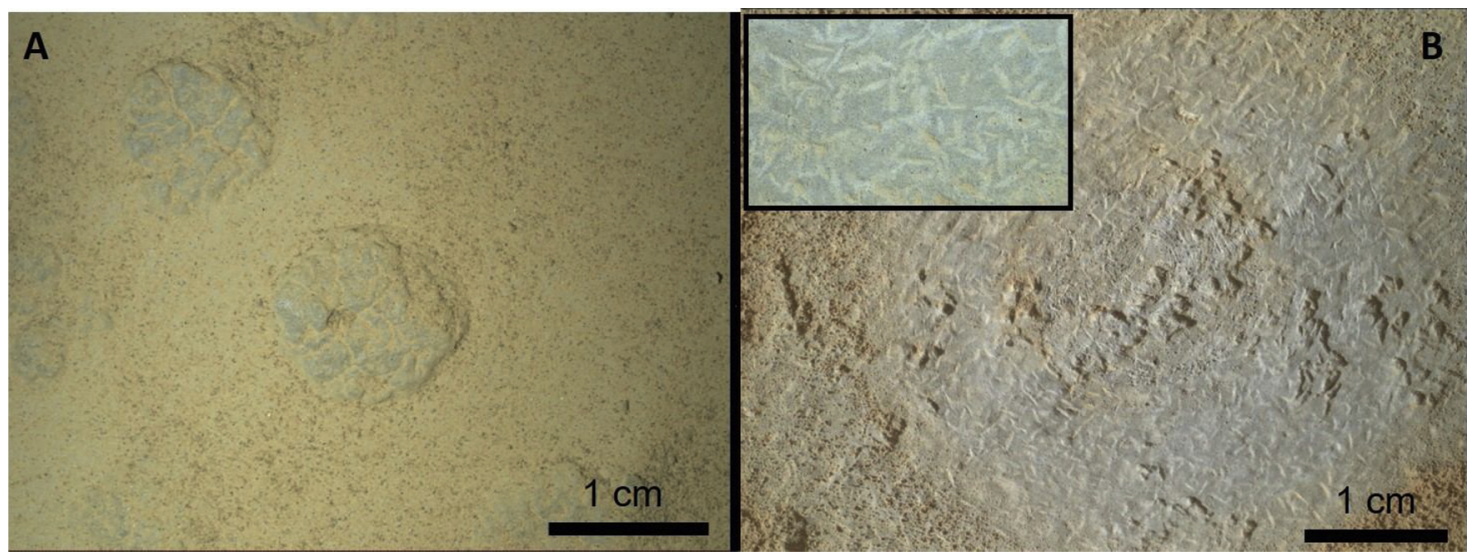

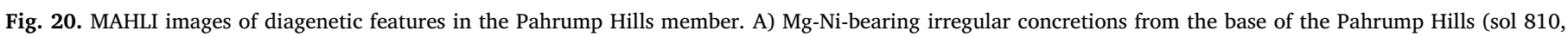

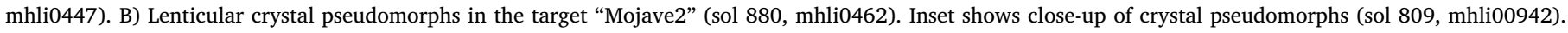
Image credits: NASA/JPL-Caltech/MSSS. 
Although the geochemistry suggests hydrothermal alteration in certain locations along Curiosity's traverse (e.g., based on Ge enrichments; Berger et al., 2017; Yen et al., 2020), and there is some mineralogical evidence for localized hydrothermalism (Rampe et al., 2020), CheMin has not detected abundant or widespread hydrothermal phases, like serpentine, chlorite, and prehnite, which have been detected from orbit in other locations on Mars (e.g., Ehlmann and Edwards, 2014). The absence of carbonate minerals above the detection limit of CheMin $(\sim 1 \mathrm{wt} . \%)$ in these samples suggests that either the lake waters were not in equilibrium with the $\mathrm{CO}_{2}$-rich early martian atmosphere or that the $\mathrm{pCO}_{2}$ of the early martian atmosphere was lower than predicted by climate models that use $\mathrm{CO}_{2}$ to warm the martian surface above the freezing point of water (Bristow et al., 2017). The relative paucity of phosphate minerals detected by CheMin, on the other hand, may be related to their detection limit in CheMin rather than their absence in Gale crater sediments. For example, all samples contain $\sim 0.5-1.3 \mathrm{wt} \% \%$ $\mathrm{P}_{2} \mathrm{O}_{5}$ from APXS measurements, so if all $\mathrm{P}_{2} \mathrm{O}_{5}$ was present in a single phase, it should be detected by CheMin. This suggests that there are multiple phosphate minerals in Gale crater such that they are below the instrument's detection limit, phosphates are X-ray amorphous, and/or phosphate is chemisorbed to mineral or mineraloid surfaces (e.g., Rampe et al., 2016). Finally, the absence of abundant and pervasive evaporite minerals, contrary to what was observed in the Burns formation in Meridiani Planum by the Mars Exploration Rover Opportunity (e.g., Grotzinger et al., 2005; McLennan et al., 2005), indicates that lake waters in Gale crater were not especially saline. Although Ca-sulfate minerals are abundant in some samples from the Murray formation, some of these are clearly late diagenetic fracture fill. We do not know how much is present in the matrix and could have precipitated from saline lake waters. Petrography of returned samples would be necessary for this evaluation. These constraints on aqueous environments from quantitative mineralogy allow us to evaluate the habitability of early Gale crater.

\section{Evidence for habitable environments at Gale crater}

Curiosity has found evidence for a long history of liquid water at Gale crater. Liquid water was present for perhaps millions of years on the surface (based on the extent and thickness of fluvio-lacustrine deposits) and spanned over a billion years in the subsurface through radiometric dating of secondary jarosite (Martin et al., 2017; though groundwater was likely present intermittently). SAM-derived $\mathrm{D} / \mathrm{H}$ ratios of the structurally bound $\mathrm{OH}$ in phyllosilicates in Yellowknife Bay are half those of the modern martian atmosphere, but much higher than those expected for very early Mars, suggesting an extended history of water loss from the martian surface (Mahaffy et al., 2015). Furthermore, ${ }^{36} \mathrm{Ar} /{ }^{38} \mathrm{Ar}$ ratios measured by SAM from the modern martian atmosphere suggest Mars has experienced significant atmospheric loss over time (Atreya et al., 2013), consistent with data measured of the upper martian atmosphere from orbit with the Mars Atmosphere and Volatile EvolutioN (MAVEN) mission (e.g., Jakosky et al., 2017). Models of $\mathrm{CO}_{2}$ gas loss by the same sputtering process that caused the loss of Ar suggest that a half bar or more of $\mathrm{CO}_{2}$ could have been lost over Mars' history (Jakosky et al., 2017). This heavier $\mathrm{CO}_{2}$-rich early martian atmosphere may have allowed for the persistent lakes at Gale crater.

The mineralogy and geochemistry of the ancient lake sediments indicate that some of these lacustrine environments had low salinity. The Sheepbed mudstone lacked chlorides and sulfate in the matrix (at least at levels above $\sim 1 \mathrm{wt} . \%$ ) and had low S and $\mathrm{Cl}$ (Grotzinger et al., 2014; McLennan et al., 2014; Vaniman et al., 2014), suggesting lake waters were relatively fresh. Calculations of pore water salinity using bulk geochemistry and the hydration state of smectite suggest the last groundwater to interact with the sediment was hyposaline with $\sim 0.1$ $0.5 \mathrm{~mol} / \mathrm{kg} \mathrm{NaCl}$ (Fukushi et al., 2019). Other portions of the section had abundant sulfate minerals, suggesting some fluids in Gale crater were enriched in soluble sulfate salts (e.g., the lake and/or groundwater that deposited the matrix Ca-sulfate detected in the "Oudam," "Marimba," "Quela," and "Sebina" samples from the Karasburg and Sutton Island members; Bristow et al., 2018; Achilles et al., submitted). At least some of the diagenetic fluids were also acidic (e.g., the groundwater from which jarosite precipitated in "Mojave2"; Rampe et al., 2017). The observation of sulfate-bearing and acidic groundwater does not preclude these environments from being habitable. On Earth, microorganisms thrive in evaporite settings, where Ca-sulfate minerals precipitate (e.g., Demergasso et al., 2004), and diverse photosynthetic eukaryotes, chemolithic bacteria, and a variety of heterotrophs exist in acid-sulfate mine drainage in Rio Tinto, Spain (e.g., Fernández-Remolar et al., 2005). In most instances, however, these microorganisms stemmed from ancestors that evolved under clement conditions, so the acidic and sulfate-rich diagenetic environments in Gale crater may not have been ideal locations for the genesis of microbial life (e.g., Squyres and Knoll, 2005).

Curiosity has also discovered all the chemical ingredients necessary to support microbial life. The essential elements $\mathrm{C}, \mathrm{H}, \mathrm{N}, \mathrm{O}, \mathrm{P}$, and $\mathrm{S}$ have been found in deposits throughout the traverse. SAM detected organic molecules in samples from the Sheepbed mudstone and from the Pahrump Hills member. Chlorobenzene and dichloroalkanes were detected up to 300 parts per billion in the Cumberland sample at relatively low temperatures between 200 and $450{ }^{\circ} \mathrm{C}$ (Freissinet et al., 2015). Thiophenes, two isomers of methylthiophene methanethiol, and dimethylsulfide are present in the Confidence Hills and Mojave2 samples as evidenced from high-temperature evolution $\left(>600{ }^{\circ} \mathrm{C}\right)$ (Eigenbrode et al., 2018). The diversity of organic molecules observed at high temperature could result from the protection by sulfate minerals or from the incorporation of sulfur into the molecules, which likely protected the organic molecules from degradation by ionizing and oxidizing conditions at the martian surface (Eigenbrode et al., 2018). Total organic carbon (TOC) contents of these samples is $\sim 0.01-0.1$ mmol C (Eigenbrode et al., 2018). For comparison to Earth, saline lake sediments in the Antarctic Dry Valleys have TOC contents of $\sim 15-300$ mmol C (Matsumoto et al., 1984, 1989). The origin of the organic molecules found at Gale crater is not known, but could include martian sources (e.g., igneous, hydrothermal, atmospheric, or biological) or exogenous sources such as meteorites, comets, or interplanetary dust particles (Freissinet et al., 2015; Eigenbrode et al., 2018). The variety of temperatures at which organic molecules are released may indicate different origins of the compounds (e.g., adsorbed vs. trapped within minerals). SAM evolved gas analyses show the presence of carbonate minerals and organic molecules in trace abundances based on the observation of $\mathrm{CO}_{2(\mathrm{~g})}$ releases (e.g., Ming et al., 2014; Sutter et al., 2017). SAM data also led to the first detection of nitrate on Mars (Stern et al., 2015), and it is present in all sediments (Sutter et al., 2017). Phosphorus has been detected by APXS in nearly every target, but the speciation is not well constrained. Fluorapatite has been identified by CheMin in samples from the Pahrump Hills (Rampe et al., 2017) and in eolian sandstone (Yen et al., 2017) and inferred from simultaneous enrichments of $\mathrm{F}$ and $\mathrm{P}$ in ChemCam targets in the Bradbury group and Murray formation (Forni et al., 2015, 2017). Phosphorus enrichments were recognized in fracture-associated halos (Yen et al., 2017), but CheMin did not detect crystalline phosphate in samples collected from the halos, suggesting the phosphorus is present as an X-ray amorphous phase or adsorbed onto mineral or mineraloid surfaces (e.g., Rampe et al., 2016).

A variety of potential energy sources would have been available for martian microorganisms in ancient Gale crater. Minerals in various states of redox could have provided energy for chemolithoautotrophs (Grotzinger et al., 2014), such as the terrestrial Fe-oxidizing bacteria Pseudomonas Sp HerB. Magnetite has both Fe(II) and Fe(III), so Fe redox coupling is a potential source of energy in samples from the Yellowknife Bay formation (Bristow et al., 2015) and the Pahrump Hills member. Although sulfide minerals have not been identified above the detection 
limit of CheMin, jarosite identified in the samples from the Pahrump Hills may have formed from the alteration of Fe-sulfide (Hurowitz et al., 2017; Rampe et al., 2017), indicating S redox coupling may be another source of energy in Gale crater lakes and groundwater. On Earth, photolithotrophic sulfur-oxidizing purple bacteria use the $S$ redox potential as an energy source (e.g., Trüper, 1982). The nearly global distribution of oxychlorine at Mars' surface also raises the interest of perchlorate-reducing bacteria such as Dechlorimonas agitata, Haloferax denitrificans, or Paracoccus halodenitrificans, which use the chlorine redox cycle as a source of energy (e.g., Okeke et al., 2002; NozawaInoue et al., 2008; Lynch et al., 2019). With respect to recent habitability, the detection of a seasonal methane cycle in Gale crater with the SAM instrument is especially intriguing, because extant subsurface methane-producing bacteria is one of many explanations for this signal, including UV degradation of exogenous organic material (Webster et al., 2018).

\section{Vera Rubin ridge and beyond}

At the time of writing, after more than 2300 sols of rover operations, Curiosity had just concluded the investigation of Vera Rubin ridge (formerly called the hematite ridge), having completed drill campaigns at localities called "Duluth," "Stoer," "Highfield," and "Rock Hall" (Fig. 21). These drilling campaigns were significant because Curiosity had not successfully delivered a drilled sample to its laboratory instruments CheMin and SAM since November 2016. These were also the first four samples produced with the new feed-extended drill technique designed by the rover engineers at JPL after a problem with the drill feed mechanism precluded the nominal drilling process.

While the engineers worked on the drill, the Science Team explored Vera Rubin ridge using the science cameras and geochemical instruments ChemCam and APXS. Vera Rubin ridge is divided into two members, the Pettegrove Point member constitutes the lower part of the ridge and the Jura member constitutes the upper part. The sedimentology of the entire Vera Rubin ridge is similar to rocks stratigraphically below it, indicating the depositional environments did not change, and mudstone with fine horizontal lamination is ubiquitous, suggesting deposition in a lake environment (e.g., Edgar et al., 2018b; Fraeman et al., 2018). Orbital spectroscopy shows that portions of Vera Rubin ridge, particularly in the Pettegrove Point member, have a strong hematite spectral signature based on bands at 550 and $860 \mathrm{~nm}$ (Fraeman et al., 2013, 2016; Fig. 21), consistent with reflectance spectra from ChemCam and Mastcam (Johnson et al., 2017b; c;
Wellington et al., 2017b). CheMin analysis of the "Stoer" sample, drilled from the Pettegrove Point member, identified the most hematite of any sample drilled to date (Morris et al., 2019; Rampe et al., 2020). The overall Fe content of the bedrock, however, is not higher on Vera Rubin ridge than elsewhere in the Murray formation, suggesting that the ridge may be a product of diagenesis (e.g., Frydenvang et al., 2019; Thompson et al., 2019).

Observations from the rover show visual and geochemical heterogeneities between and within the two members that make up the ridge that suggest diagenetic fluids altered these rocks (e.g., Fraeman et al., 2018; Thompson et al., 2018). Most notably, rocks of the Jura member show a diversity of colors, with both red and gray outcrops (Fig. 22). CheMin analysis of a sample from the gray Jura ("Highfield") indicates the gray color is from abundant gray hematite (Rampe et al., 2020). Gray hematite has a coarser grain size than red hematite, where grains $>\sim 3-5 \mu \mathrm{m}$ appear gray (Catling and Moore, 2003; Morris et al., 2020). Gray hematite typically forms at elevated temperatures of $\sim 80-200{ }^{\circ} \mathrm{C}$ (Catling and Moore, 2003), and the discovery of this mineral on Vera Rubin ridge may indicate some of the diagenetic fluids were warm (Rampe et al., 2020). In the gray Jura outcrops, ChemCam has observed subhedral to euhedral mm-scale crystals of nearly pure Fe (presumably as oxides) interspersed in Ca-sulfate veins and nodules and in the bedrock (Fig. 23A,B). In other places, local enrichment of Fe is seen on millimeter scales surrounded by lighter-toned bedrock depleted in $\mathrm{Fe}$, indicating localized $\mathrm{Fe}$ mobilization in the Jura member (Fig. 23C; L'Haridon et al., 2019). The relatively coarse hematite grains in some locations and the relatively low dust content on the ridge may cause the strong hematite signature from orbit (e.g., Fraeman et al., 2020). The Science Team is currently evaluating the results from the Vera Rubin ridge campaign and will publish these results in a special issue of the Journal of Geophysical Research - Planets.

Beyond Vera Rubin ridge lie the other mineral units identified from orbit, the clay-bearing unit and the sulfate unit. Curiosity began the investigation of the clay-bearing unit (unofficially named "Glen Torridon") in January 2019. A working group devised a traverse through this unit and has identified potential locations to drill (Fig. 24). The traverse was designed to investigate different morphologic subunits, geologic contacts with Vera Rubin ridge and the sulfate unit, and a location with a strong phyllosilicate signature from orbit (Bennett et al., 2018). Orbital visible and near- to short-wave infrared spectral reflectance data from Glen Torridon are consistent with ferric smectite (Fox et al., 2018). Data from CheMin and SAM will be used to further characterize the phyllosilicate(s) present and determine whether the

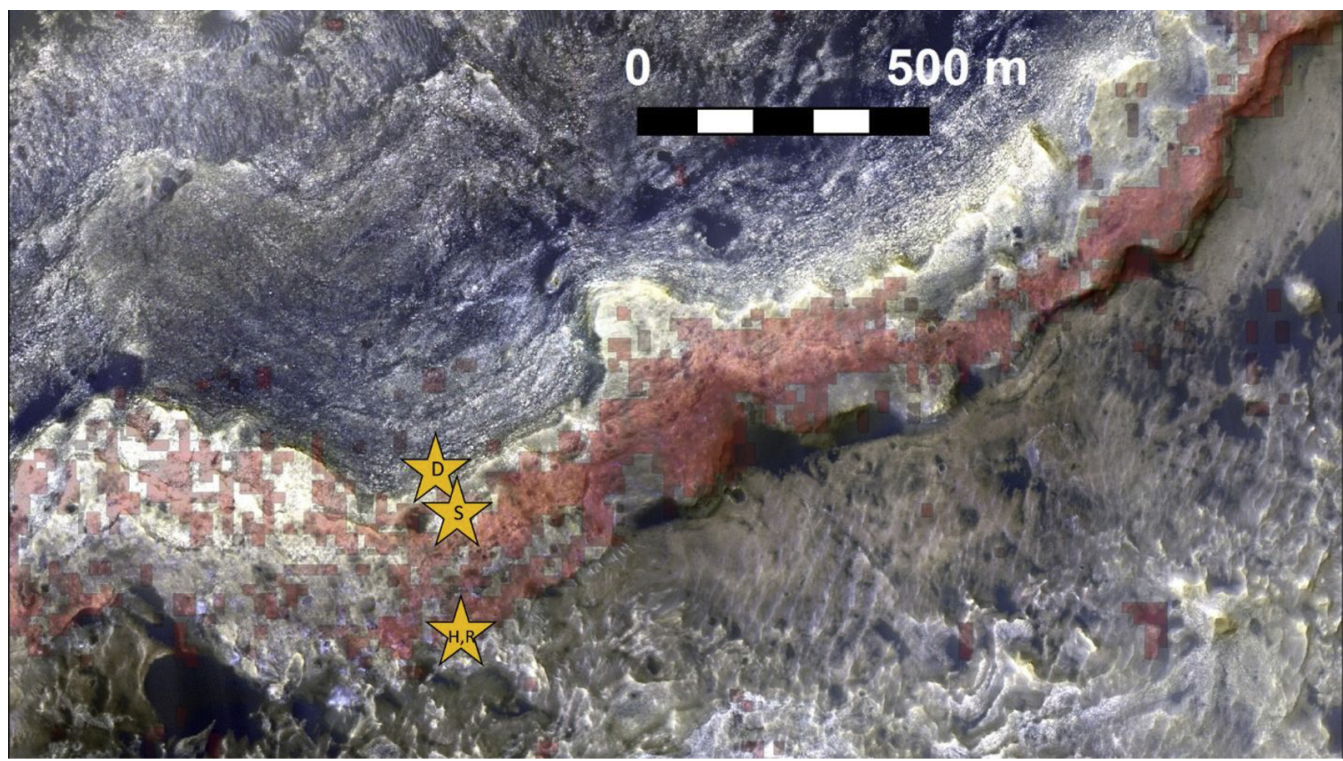

Fig. 21. Vera Rubin Ridge from orbit. The image is a HiRISE mosaic merged with CRISM detections of hematite. Red colors represent hematite mapped using orbital visible and near-infrared data from CRISM. The stars mark drill locations near and on the Vera Rubin Ridge, where D = Duluth, $\mathrm{S}=$ Stoer, $\mathrm{H}$ $=$ Highfield, and $\mathrm{R}=$ Rock Hall. Highfield and Rock Hall were drilled $\sim 30 \mathrm{~m}$ apart laterally, so their drill locations are denoted with one star. Image credit: NASA/JPL-Caltech/ JHUAPL/A. Fraeman (For interpretation of the references to colour in this figure legend, the reader is referred to the web version of this article.). 


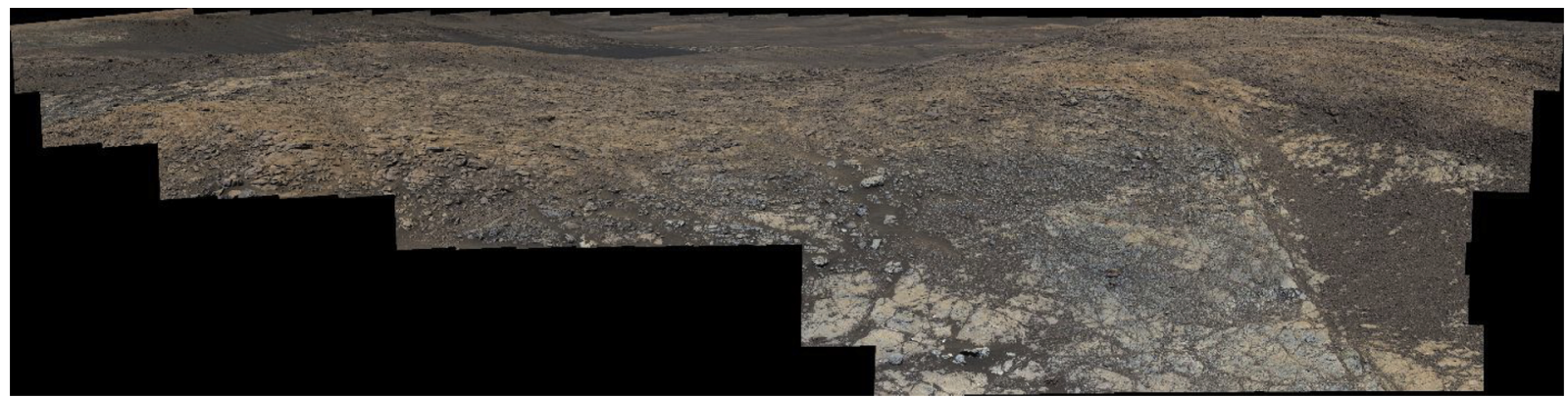

Fig. 22. Mastcam mosaic of a portion of the Jura member of the Vera Rubin Ridge, showing a variation in gray outcrop in the foreground to red outcrop in the background (sol 1931, mcam10081). Image credit: NASA/JPL-Caltech/MSSS (For interpretation of the references to colour in this figure legend, the reader is referred to the web version of this article.).
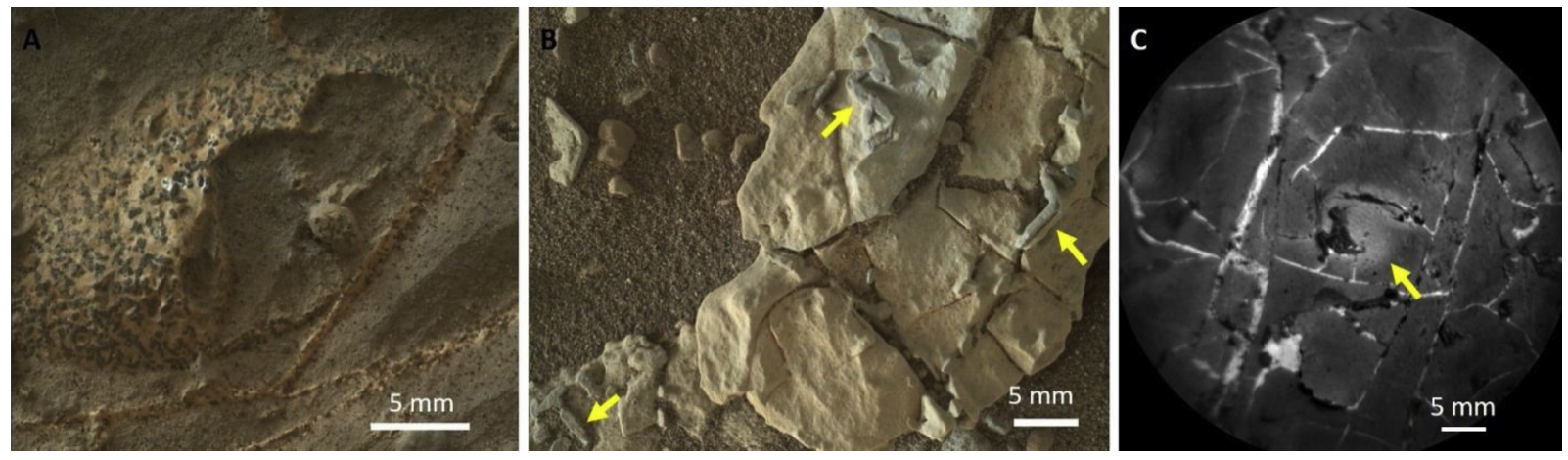

Fig. 23. Evidence for Fe mobilization in the Jura member of the Vera Rubin Ridge. A) MAHLI image of subhedral to euhedral Fe-rich crystals within a Ca-sulfate matrix (sol 2217, mhli00732). B) MAHLI image of Fe-rich linear features (sol 1922, mhli00152). C) ChemCam RMI image of Fe-rich dark materials associated with Ca-sulfate-filled fractures. Fe-rich dark materials in the center of the image are surrounded by lighter-toned Fe-poor bedrock. Arrow points to edge of light-toned halo surrounding Fe-rich material (sol 1934, ccam01934).
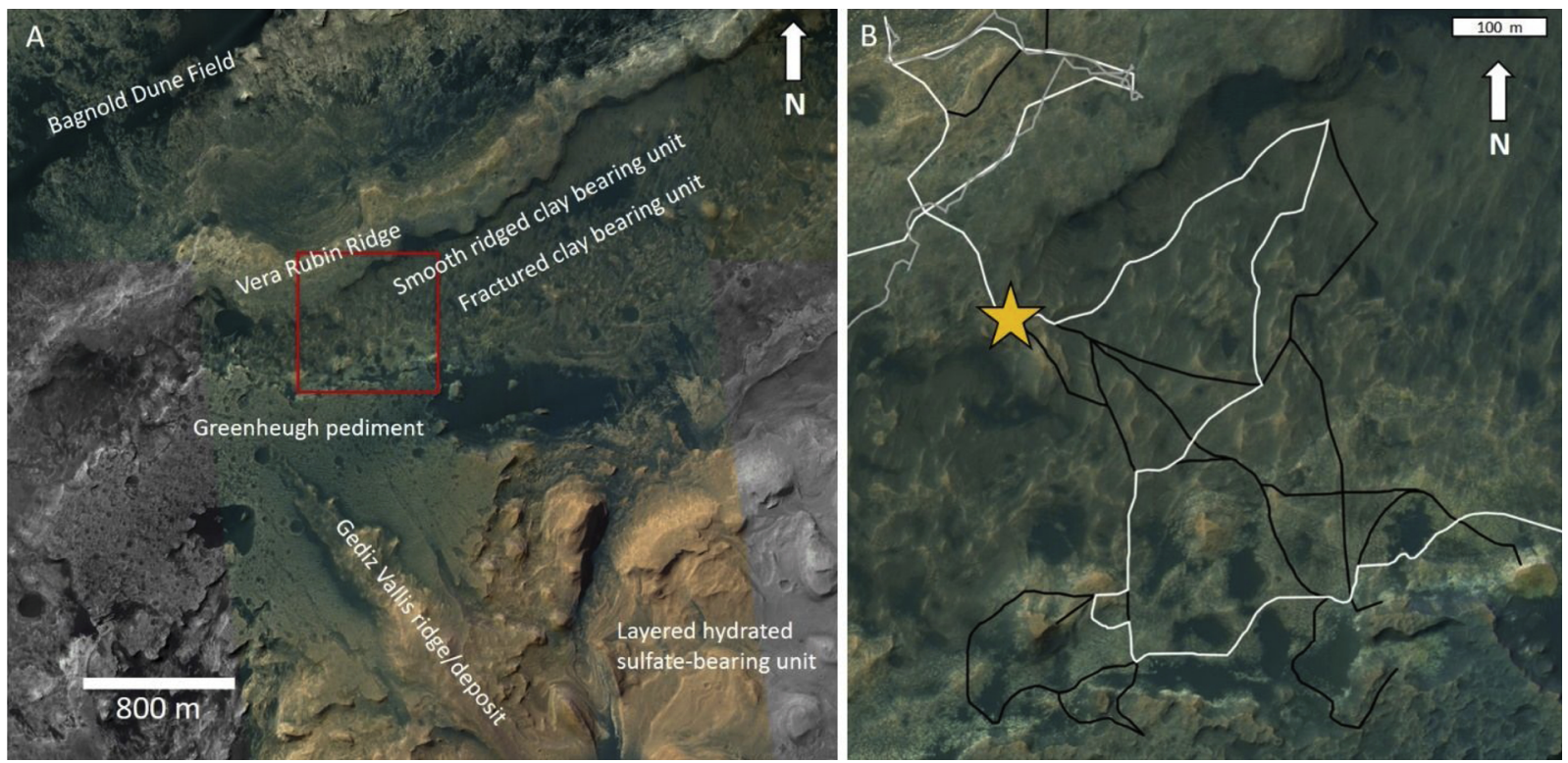

Fig. 24. A) HiRISE mosaic of the foothills of Mount Sharp and units that Curiosity will explore in current and future campaigns. The location of figure B is denoted by the red box. B) White path is the proposed route through the clay bearing unit. Black lines are other paths vetted for mobility. Gray line on the Vera Rubin Ridge shows Curiosity's traverse through sol 2084. The star denotes Curiosity's location on sol 2300. Adapted from Fox et al. (2019) (For interpretation of the references to colour in this figure legend, the reader is referred to the web version of this article.).

weathering intensity continues to increase going up Mount Sharp (Bristow et al., 2018; Mangold et al., 2019). Clay minerals can also become concentrated by sediment sorting and provide long-term preservation of organic molecules, due to high surface areas and charged interlayer sites (e.g., Bonaccorsi, 2011). As such, the clay-bearing unit is a promising target for SAM investigation of organic molecules. The plan for the next few years is to explore the units that made Gale crater such an attractive landing site, further explore the evolution of ancient aqueous environments at Gale crater, and evaluate their habitability. 


\section{Contact with the editorial office}

This author submitted this manuscript using his/her account in EVISE.

We understand that this Corresponding Author is the sole contact for the Editorial process (including EVISE and direct communications with the office). $\mathrm{He} / \mathrm{she}$ is responsible for communicating with the other authors about progress, submissions of revisions and final approval of proofs.

We confirm that the email address shown below is accessible by the Corresponding Author, is the address to which Corresponding Author's EVISE account is linked, and has been configured to accept email from the editorial office of American Journal of Ophthalmology Case Reports.

\section{Authorship}

All listed authors meet the ICMJE criteria. We attest that all authors contributed significantly to the creation of this manuscript, each having fulfilled criteria as established by the ICMJE.

We confirm that the manuscript has been read and approved by all named authors.

We confirm that the order of authors listed in the manuscript has been approved by all named authors.

\section{Research ethics}

We further confirm that any aspect of the work covered in this manuscript that has involved human patients has been conducted with the ethical approval of all relevant bodies and that such approvals are acknowledged within the manuscript.

\section{Intellectual property}

We confirm that we have given due consideration to the protection of intellectual property associated with this work and that there are no impediments to publication, including the timing of publication, with respect to intellectual property. In so doing we confirm that we have followed the regulations of our institutions concerning intellectual property.

Funding

Funding was received for this work.

\section{Declaration of Competing Interest}

No conflict of interest exists.

\section{Acknowledgements}

We gratefully acknowledge the MSL engineering team for enabling the collection of these exceptional scientific datasets. We thank two anonymous reviewers for their thoughtful comments and thorough reviews that improved this manuscript. We also thank S. VanBommel for discussions that improved the manuscript. Some of this research was carried out at the Jet Propulsion Laboratory, California Institute of Technology, under a contract with the National Aeronautics and Space Administration. This work was supported in the U.S. by NASA's Mars Exploration Program through the MSL mission. A portion of this research was supported by NASA NNX11AP82A, MSL Investigations, and by the National Science Foundation Graduate Research Fellowship under Grant No. DGE-1143953. J. R. Johnson acknowledges support from the MSL Participating Scientist Program subcontract 1546033. Any opinions, findings or recommendations expressed herein are those of the authors and do not necessarily reflect the views of the National
Aeronautics and Space Administration or the National Science Foundation. This Invited Review was solicited and handled by Associate Editor Klaus Keil.

\section{References}

Achilles, C.N., Downs, R.T., Ming, D.W., Rampe, E.B., Morris, R.V., Treiman, A.H., Morrison, S.M., Blake, D.F., Vaniman, D.T., Ewing, R.C., Chipera, S.J., Yen, A.S., Bristow, T.F., Ehlmann, B.L., Gellert, R., Hazen, R.M., Fendrich, K.V., Craig, P.I., Grotzinger, J.P., Des Marais, D.J., Farmer, J.D., Sarrazin, P.C., Morookian, J.M., 2017. Mineralogy of an active eolian sediment from the Namib dune, Gale crater, Mars. J. Geophys. Res. Planets 122 (11), 2344-2361.

Achilles, C.N., Rampe, E.B., Downs, R.T., Bristow, T.F., Ming, D.W., Morris, R.V., Vaniman, D.T., Blake, D.F., Yen, A.S., McAdam, A.C., Sutter, B., Fedo, C.M., Gwizd, S., Thompson, L.M., Gellert, R., Morrison, S.M., Treiman, A.H., Crisp, J.A., Gabriel, T.S.J., Chipera, S.J., Hazen, R.M., Craig, P.I., Thorpe, M.T., Des Marais, D.J., Grotzinger, J.P., Tu, V.M., Castle, N., Downs, G.W., Peretyazhko, T.S., Walroth, R.C., Sarrazin, P., Morookian, J.M., 2020. Evidence for multiple diagenetic episodes in ancient fluvial-lacustrine sedimentary rocks in Gale crater, Mars. J. Geophys. Res. Planets Submitted for publication.

Anderson, R.B., Bell III, J.F., 2010. Geologic mapping and characterization of Gale crater and implications for its potential as a Mars Science Laboratory landing site. Mars 5, 76-128.

Anderson, R.C., Jandura, L., Okon, A.B., Sunshine, D., Roumeliotis, C., Beegle, L.W., Hurowitz, J., Kennedy, B., Limonadi, D., McCloskey, S., Robinson, M., Seybold, C., Brown, K., 2012. Collecting samples in Gale crater, Mars; an overview of the Mars Science Laboratory sample acquisition, sample processing and handling system. Space Sci. Rev. 170 (1-4), 57-75.

Anderson, R., Bridges, J.C., Williams, A., Edgar, L., Ollila, A., Williams, J., Nachon, M. Mangold, N., Fisk, M., Schieber, J., Gupta, S., Dromart, G., Wiens, R., Le Mouelic, S., Forni, O., Lanza, N., Mezzacappa, A., Sautter, V., Blaney, D., Clark, B., Clegg, S., Gasnault, O., Lasue, J., Leveille, R., Lewin, E., Lewis, K.W., Maurice, S., Newsom, H., Schwenzer, S.P., Vaniman, D.T., 2015. ChemCam results from the Shaler outcrop in Gale crater, Mars. Icarus 249, 2-21.

Atreya, S.K., Trainer, M.G., Franz, H.B., Wong, M.H., Manning, H.L., Malespin, C.A., Mahaffy, P.R., Conrad, P.G., Brunner, A.E., Leshin, L.A., Jones, J.H., Webster, C.R., Owen, T.C., Pepin, R.O., Navarro-Gonzalez, R., 2013. Primordial argon isotope fractionation in the atmosphere of Mars measured by the SAM instrument on Curiosity and implications for atmospheric loss. Geophys. Res. Lett. 40 (21), $5605-5609$.

Banham, S.G., Gupta, S., Rubin, D.M., Watkins, J.A., Sumner, D.Y., Edgett, K.S., Grotzinger, J.P., Lewis, K.W., Edgar, L.A., Stack-Morgan, K.M., Barnes, R., Bell III, J.F., Day, M.D., Ewing, R.C., Lapotre, M.G.A., Stein, N.T., Rivera-Hernandez, F, Vasavada, A.R., 2018. Ancient Martian aeolian processes and palaeomorphology reconstructed from the Stimson formation on the lower slope of Aeolis Mons, Gale crater, Mars. Sedimentology 65 (4), 993-1042.

Bedford, C.C., Bridges, J.C., Schwenzer, S.P., Wiens, R.C., Rampe, E.B., Frydenvang, J., Gasda, P.J., 2019. Alteration trends and geochemical source region characteristics preserved in the fluviolacustrine sedimentary record of Gale crater, Mars. Geochim. Cosmochim. Acta 246, 234-266.

Bell III, J.F., Godber, A., McNair, S., Caplinger, M.A., Maki, J.N., Lemmon, M.T., Van Beek, J., Malin, M.C., Wellington, D., Kinch, K.M., Madsen, M.B., Hardgrove, C., Ravine, M.A., Jensen, E., Harker, D., Anderson, R.B., Herkenhoff, K.E., Morris, R.V., Cisneros, E., Deen, R.G., 2017. The Mars Science Laboratory Curiosity rover Mastcam instruments: Preflight and in-flight calibration, validation, and data archiving. Earth Space Sci. 4. https://doi.org/10.1002/2016EA000219.

Bennett, K.A., Fox, V.K., Vasavada, A.R., Grotzinger, J.P., Edwards, C.S., 2018. The Claybearing unit in gale crater II: plans for the investigation of the Clay-bearing unit by the Curiosity rover. Lunar and Planetary Science Conference Vol. 49.

Berger, J.A., Schmidt, M.E., Gellert, R., Campbell, J.L., King, P.L., Flemming, R.L., Ming, D.W., Clark, B.C., Pradler, I., VanBommel, S.J.V., Minitti, M.E., Fairen, A.G., Boyd, N.I., Thompson, L.M., Perrett, G.M., Elliott, B.E., Desouza, E., 2016. A global Mars dust composition refined by the Alpha-Particle X-ray Spectrometer in Gale crater. Geophys. Res. Lett. 43 (1), 67-75. https://doi.org/10.1002/2015GL066675.

Berger, J.A., Schmidt, M.E., Gellert, R., Boyd, N.I., Desouza, E.D., Flemming, R.L., Izawa, M.R.M., Ming, D.W., Perrett, G.M., Rampe, E.B., Thompson, L.M., VanBommel, S.J.V., Yen, A.S., 2017. Zinc and germanium in the sedimentary rocks of Gale crater on Mars indicate hydrothermal enrichment followed by diagenetic fractionation. J. Geophys. Res. - Planets 122 (8), 1747-1772.

Bibring, J.P., Langevin, Y., Mustard, J.F., Poulet, F., Arvidson, R., Gendrin, A., Gondet, B., Mangold, N., Pinet, P., Forget, F., the OMEGA team, Berthé, M., Bibring, J.-P., Gomez, C., Jouglet, D., Soufflot, A., Vincendon, M., Combes, M., Drossart, P., Encrenaz, T., Fouchet, T., Merchiorri, R., Belluci, G., Altieri, F., Formisano, V., Capaccioni, F., Cerroni, P., Coradini, A., Fonti, S., Korablev, Kottosov, V., Ignatiev, N., Moroz, V., Titov, D., Zasova, L., Loiseau, D., Doute, S., Schmitt, B., Sotin, C., Hauber, E., Hoffmann, H., Jaumann, R., Keller, U., Arvidson, R., Duxbury, T., Neukum, G., 2006. Global mineralogical and aqueous Mars history derived from OMEGA/Mars Express data. Science 312 (5772), 400-404.

Bish, D.L., Howard, S.A., 1988. Quantitative phase analysis using the Rietveld method. J. Appl. Crystallogr. 21 (2), 86-91.

Bish, D.L., Blake, D.F., Vaniman, D.T., Chipera, S.J., Morris, R.V., Ming, D.W., Treiman, A.H., Sarrazin, P., Morrison, S.M., Downs, R.T., Achilles, C.N., Yen, A.S., Bristow, T.F., Crisp, J.A., Morookian, J.M., Farmer, J.D., Rampe, E.B., Stolper, E.M., Spanovich, N., Science Team, M.S.L., 2013. X-ray diffraction results from Mars 
Science Laboratory: Mineralogy of Rocknest at Gale crater. Science 341 (6153), 1238932

Blake, D., Vaniman, D., Achilles, C., Anderson, R., Bish, D., Bristow, T., Chen, C., Chipera, S., Crisp, J., Des Marais, D., Downs, R.T., Farmer, J., Feldman, S., Fonda, M., Gailhanou, M., Ma, H., Ming, D.W., Morris, R.V., Sarrazin, P., Stolper, E., Treiman, A., Yen, A., 2012. Characterization and calibration of the CheMin mineralogical instrument on Mars Science Laboratory. Space Sci. Rev. 170 (1-4), 341-399.

Blake, D.F., Morris, R.V., Kocurek, G., Morrison, S.M., Downs, R.T., Bish, D., Ming, D.W., Edgett, K.S., Rubin, D., Goetz, W., Madsen, M.B., Sullivan, R., Gellert, R., Campbell, I., Treiman, A.H., McLennan, S.M., Yen, A.S., Grotzinger, J., Vaniman, D.T., Chipera, S.J., Achilles, C.N., Rampe, E.B., Sumner, D., Meslin, P.-Y., Maurice, S., Forni, O., Gasnault, O., Fisk, M., Schmidt, M., Mahaffy, P., Leshin, L.A., Glavin, D., Steele, A., Freissinet, C., Navarro-Gonzalez, R., Yingst, R.A., Kah, L.C., Bridges, N., Lewis, K.W., Bristow, T.F., Farmer, J.D., Crisp, J.A., Stolper, E.M., Des Marais, D.J., Sarrazin, P., MSL Science Team, 2013. Curiosity at Gale crater, Mars: characterization and analysis of the Rocknest sand shadow. Science 341 (6153), 1239505.

Bonaccorsi, R., 2011. Preservation potential and habitability of clay minerals-and ironrich environments: novel analogs for the 2011 Mars science laboratory mission. STROMATOLITES: Interaction of Microbes With Sediments. Springer, Dordrecht, pp. 705-722.

Borlina, C.S., Ehlmann, B.L., Kite, E.S., 2015. Modeling the thermal and physical evolution of Mount Sharp's sedimentary rocks, Gale crater, Mars: implications for diagenesis on the MSL Curiosity rover traverse. J. Geophys. Res. - Planets 120 (8), 1396-1414.

Breuer, D., Spohn, T., 2003. Early plate tectonics versus single-plate tectonics on Mars: evidence from magnetic field history and crust evolution. J. Geophys. Res. Planets 108 (E7).

Bridges, N.T., Ehlmann, B.L., 2018. The mars science laboratory (MSL) Bagnold Dunes campaign, phase I: overview and introduction to the special issue. J. Geophys. Res. Planets 123 (1) 3-19.

Bridges, J.C., Schwenzer, S.P., Léveillé, R., Westall, F., Wiens, R.C., Mangold, N., Bristow, T., Edwards, P., Berger, G., 2015. Diagenesis and clay mineral formation at Gale Crater, Mars. J. Geophys. Res. - Planets. https://doi.org/10.1002/2014JE00475.

Bristow, T.F., Bish, D.L., Vaniman, D.T., Morris, R.V., Blake, D.F., Grotzinger, J.P., Rampe, E.B., Crisp, J.A., Achilles, C.N., Ming, D.W., Ehlmann, B.L., King, P.L., Bridges, J.C., Eigenbrode, J.L., Sumner, D.Y., Chipera, S.J., Morookian, J.M., Treiman, A.H., Morrison, S.M., Downs, R.T., Farmer, J.D., Des Marais, D., Sarrazin, P., Floyd, M.M., Mischna, M.A., McAdam, A.C., 2015. The origin and implications of clay minerals from Yellowknife Bay, Gale crater, Mars. Am. Mineral. 100 (4), 824-836.

Bristow, T.F., Haberle, R.M., Blake, D.F., Des Marais, D.J., Eigenbrode, J.L., Fairén, A.G., Grotzinger, J.P., Stack, K.M., Mischna, M.A., Rampe, E.B., Siebach, K.L., Sutter, B., Vaniman, D.T., Vasavada, A.R., 2017. Low Hesperian $\mathrm{P}_{\mathrm{CO} 2}$ constrained from in situ mineralogical analysis at Gale Crater, Mars. P. Natl. Acad. Sci. 114 (9), 2166-2170.

Bristow, T.F., Rampe, E.B., Achilles, C.N., Blake, D.F., Chipera, S.J., Craig, P., Crisp, J.A., Des Marais, D.J., Downs, R.T., Gellert, R., Grotzinger, J.P., Gupta, S., Hazen, R.M., Horgan, B., Hogancamp, J.V., Mangold, N., Mahaffy, P.R., McAdam, A.C., Ming, D.W., Morookian, J.M., Morris, R.V., Morrison, S.M., Treiman, A.H., Vaniman, D.T., Vasavada, A.R., Yen, A.S., 2018. Clay mineral diversity and abundance in sedimentary rocks of Gale crater, Mars. Sci. Adv(6) eaar3330.

Campbell, J.L., Perrett, G.M., Gellert, R., Andrushenko, S.M., Boyd, N.I., Maxwell, J.A King, P.L., Schofield, C.D.M., 2012. Calibration of the mars science laboratory alpha particle X-ray spectrometer. Space Sci. Rev. 170 (1-4), 319-340.

Castle, N., Treiman, A.H., 2019. Systematic error and the identification of minor phases using the CheMin X-ray diffractometer. Lunar and Planetary Science Conference, vol. 50 .

Catling, D.C., Moore, J.M., 2003. The nature of coarse-grained crystalline hematite and its implications for the early environment of Mars. Icarus 165 (2), 277-300.

Che, C., Glotch, T.D., Bish, D.L., Michalski, J.R., Wenqian, X., 2011. Spectroscopic study of the dehydration and/or dehydroxylation of phyllosilicate and zeolite minerals. J. Geophys. Res. Planets 116 (E5). https://doi.org/10.1029/2010JE003740.

Chipera, S.J., Bish, D.L., 2002. FULLPAT: a full-pattern quantitative analysis program for X-ray powder diffraction using measured and calculated patterns. J. Appl. Crystallogr. 35 (6), 744-749.

Chipera, S.J., Bish, D.L., 2013. Fitting full X-ray diffraction patterns for quantitative analysis: a method for readily quantifying crystalline and disordered phases. Adv. Mater. Phys. Chem. 3 (01), 47.

Cousin, A., Sautter, V., Payré, V., Forni, O., Mangold, N., Gasnault, O., Le Deit, L., Johnson, J., Maurice, S., Salvatore, M., Wiens, R.C., Gasda, P., Rapin, W., 2017a. Classification of igneous rocks analyzed by ChemCam at Gale crater, Mars. Icarus 288, 265-283.

Cousin, A., Dehouck, E., Meslin, P.-Y., Forni, O., Williams, A.J., Stein, N., Gasnault, O., Bridges, N., Ehlmann, B., Schröder, S., Payré, V., Rapin, W., Pinet, P., Sautter, V., Lanza, N., Lasue, J., Maurice, S., Wiens, R.C., 2017b. Geochemistry of the Bagnold dune field as observed by ChemCam and comparison with other aeolian deposits at Gale crater. J. Geophys. Res. - Planets 122 (10), 2144-2162.

Craddock, R.A., Maxwell, T.A., 1993. Geomorphic evolution of the Martian highlands through ancient fluvial processes. J. Geophys. Res. - Planets 98 (E2), 3453-3468.

Dehouck, E., McLennan, S.M., Meslin, P.-Y., Cousin, A., 2014. Constraints on abundance, composition, and nature of X-ray amorphous components of soils and rocks at Gale crater, Mars. J. Geophys. Res. - Planets 119 (12), 2640-2657. https://doi.org/10. 1002/2014je004716.

Del Moro, S., Renzulli, A., Tribaudino, M., 2011. Pyrometamorphic processes at the magma-hydrothermal system interface of active volcanoes: evidence from buchite ejecta of Stromboli (aeolian Islands, Italy). J. Petrol. 52 (3), 541-564.

Demergasso, C., Casamayor, E.O., Chong, G., Galleguillos, P., Escudero, L., Pedrós-Alió,
C., 2004. Distribution of prokaryotic genetic diversity in athalassohaline lakes of the Atacama desert, Northern Chile. FEMS Microbiol. Ecol. 48 (1), 57-69.

Denoyer de Segonzac, G., 1970. The transformation of clay minerals during diagenesis and low-grade metamorphism: a review. Sedimentology 15, 281-346.

Dera, P., Zhuravlev, K., Prakapenka, V., Rivers, M.L., Finkelstein, G.J., Grubor-Urosevic, O., Tschauner, O., Clark, S.M., Downs, R.T., 2013. High pressure single-crystal micro X-ray diffraction analysis with GSE_ADA/RSV software. High Pressure Res. 33 (3), 466-484.

Driscoll, R., Leinz, R., 2005. Methods for Synthesis of Some Jarosites. USGS Tech. Methods 5-D1 5 pp.

Edgar, L.A., Gupta, S., Rubin, D.M., Lewis, K.W., Kocurek, G.A., Anderson, R.B., Bell III, J.F., Dromart, G., Edgett, K.S., Grotzinger, J.P., Hardgrove, C., Kah, L.C., Leveille, R., Malin, M.C., Mangold, N., Milliken, R.E., Minitti, M., Palucis, M., Rice, M., Rowland, S.K., Schieber, J., Stack, K.M., Sumner, D.Y., Wiens, R.C., Williams, R.M.E., Williams, A.J., 2018a. Shaler: in situ analysis of a fluvial sedimentary deposit on Mars. Sedimentology 65 (1), 96-122.

Edgar, L.A., Fraeman, A.A., Gupta, S., Fedo, C.M., Grotzinger, J.P., Stack, K.M., Bennet, K.A., Sun, V.Z., Banham, S.G., Stein, N.T., Edgett, K.S., Rubin, D.M., Van Beek, J., 2018b. Sedimentology and stratigraphy observed at Vera Rubin Ridge by the Mars science laboratory Curiosity rover. Lunar and Planetary Science Conference (Vol. 49).

Edgett, K.S., Yingst, R.A., Ravine, M.A., Caplinger, M.A., Maki, J.N., Ghaemi, F.T., Schaffner, J.A., Bell III, J.F., Edwards, L.J., Herkenhoff, K.E., Heydari, E., Kah, L.C., Lemmon, M.T., Minitti, M.E., Olson, T.S., Parker, T.J., Rowland, S.K., Schieber, J., Sullivan, R.J., Sumner, D.Y., Thomas, P.C., Jensen, E.H., Simmonds, J.J., Sengstacken, A.J., Wilson, R.G., Goetz, W., 2012. Curiosity's Mars hand lens imager (MAHLI) investigation. Space Sci. Rev. 170 (1-4), 259-317.

Edwards, P.H., Bridges, J.C., Wiens, R.C., Anderson, R., Dyar, D., Fisk, M., Thompson, L., Gasda, P., Filiberto, J., Schwenzer, S.P., Blaney, D., Hutchinson, I., 2017. Basalttrachybasalt samples from Gale crater. Mars. Meteorit. Planet. Sci. 52 2931-2410.

Ehlmann, B.L., Buz, J., 2015. Mineralogy and fluvial history of the watersheds of Gale, knobel, and Sharp craters: a regional context for the Mars Science Laboratory Curiosity's exploration. Geophys. Res. Lett. 42 (2), 264-273.

Ehlmann, B.L., Edwards, C.S., 2014. Mineralogy of the martian surface. Annu. Rev. Earth Pl. Sc. 42, 291-315.

Eigenbrode, J.L., Summons, R.E., Steele, A., Freissinet, C., Millan, M., Navarro-González, R., Sutter, B., McAdam, A.C., Franz, H.B., Glavin, D.P., Archer Jr., P.D., Mahaffy, P.R., Conrad, P.G., Hurowitz, J.A., Grotzinger, J.P., Gupta, S., Ming, D.W., Sumner, D.Y., Szopa, C., Malespin, C., Buch, A., Coll, P., 2018. Organic matter preserved in 3-billion-year-old mudstones at Gale crater, Mars. Science 360 (6393), 1096-1101.

Fedo, C.M., 2000. Setting and origin for problematic rocks from the \&3.7 Ga Isua Greenstone Belt, southern west Greenland: earth's oldest coarse clastic sediments. Precambrian Res. 101 (1), 69-78.

Fedo, C.M., Grotzinger, J.P., Gupta, S., Fraeman, A., Edgar, L., Edgett, K., Stein, N., Rivera-Hernandez, F., Lewis, K., Stack, K.M., House, C., Rubin, D., Vasavada, A.R., 2018. Sedimentology and stratigraphy of the Murray formation, Gale crater, Mars. Lunar and Planetary Science Conference (Vol. 49).

Fernández-Remolar, D.C., Morris, R.V., Gruener, J.E., Amils, R., Knoll, A.H., 2005. The Rio Tinto Basin, Spain: mineralogy, sedimentary geobiology, and implications for interpretation of outcrop rocks at Meridiani Planum, Mars. Earth Planet. Sci. Lett. 240 (1), 149-167.

Forni, O., Gaft, M., Toplis, M., Clegg, S.M., Sautter, V., Maurice, S., Wiens, R.C., Mangold, N., Gasnault, O., Sautter, V., Le Mouélic, S., Meslin, P.-Y., Nachon, M., McInroy, R.E., Ollila, A.M., Cousin, A., Bridges, J.C., Lanza, N.L., Dyar, M.D., 2015. First detection of fluorine on mars: implications on Gale crater's geochemistry. Geophys. Res. Lett. 42. https://doi.org/10.1002/2014GL062742.

Forni, O., Meslin, P.-Y., L'Haridon, J., Rapin, W., Nachon, M., Newsom, H., Mangold, N., Gasnault, O., Anderson, D.E., Anderson, R.B., Blaney, D.L., Clegg, S.M., Cousin, A., Dehouck, E., Johnson, J.R., Lanza, N.L., Lasue, J., Maurice, S., Wiens, R.C., 2017. Detection of fluorine-rich phases, phosphates, and halite in the Stimson-Murray units, Gale crater, Mars. Lunar and Planetary Science Conference (Vol. 48).

Fox, V.K., Bennett, K.A., Vasavada, A.R., Stack, K.M., Ehlmann, B.L., 2018. The Claybearing unit of Mount sharp, Gale crater, I: orbital perspective and initial results. Lunar and Planetary Science Conference (Vol. 49).

Fox, V.K., Bennett, K.A., Ehlmann, B., House, C., Fairén, A.G., Horgan, B., Johnson, S., Salvatore, M., Stack, K., Williams, R.C., Williams, A.J., 2019. Exploring the claybearing unit with the Curiosity rover. Lunar and Planetary Science Conference (Vol. 50).

Fraeman, A.A., Arvidson, R.E., Catalano, J.G., Grotzinger, J.P., Morris, R.V., Murchie, S.L., Stack, K.M., Humm, D.C., McGovern, J.A., Seelos, F.P., Seelos, K.D., Viviano, C.E., 2013. A hematite-bearing layer in Gale crater, Mars: mapping and implications for past aqueous conditions. Geology 41 (10), 1103-1106.

Fraeman, A.A., Ehlmann, B.L., Arvidson, R.E., Edwards, C.S., Grotzinger, J.P., Milliken, R.E., Quinn, D.P., Rice, M.S., 2016. The stratigraphy and evolution of lower Mount Sharp from spectral, morphological, and thermophysical orbital data sets. J. Geophys. Res. - Planets 121 (9), 1713-1736.

Fraeman, A.A., Edgar, L.A., Grotzinger, J.P., Vasavada, A.R., Johnson, J.R., Wellington, D.F., Fox, V.K., Sun, V.Z., Hardgrove, C.J., Horgan, B.N., House, C.H., Johnson, S.S., Stack Morgan, K.M., Rampe, E.B., Thompson, L.M., Wiens, R.C., Williams, A.J., 2018. Curiosity's investigation at Vera Rubin Ridge. Lunar and Planetary Science Conference (Vol. 49).

Fraeman, A.A., Johnson, J.R., Arvidson, R.E., Rice, M.S., Wellington, D.F., Morris, R.V., Fox, V.K., Horgan, B.H., Jacob, S.R., Salvatore, M.R., Sun, V.Z., Pinet, P., Bell, J.F. III, Wiens, R.C., Vasavada, A.R., submitted. Synergistic ground and orbital observations of iron oxides on Mt. Sharp and Vera Rubin ridge. J. Geophys. Res. - Planets.

Francis, R., Estlin, T., Doran, G., Johnstone, S., Gaines, D., Verma, V., Burl, M., Frydenvang, J., Montaño, S., Wiens, R.C., Schaffer, S., Gasnault, O., DeFlores, L., 
Blaney, D., Bornstein, B., 2017. AEGIS autonomous targeting for ChemCam on Mars Science Laboratory: deployment and results of initial science team use. Sci. Robot. 2 (7), eaan4582.

Freissinet, C., Glavin, D.P., Mahaffy, P.R., Miller, K.E., Eigenbrode, J.L., Summons, R.E., Brunner, A.E., Buch, A., Szopa, C., Archer Jr., P.D., Franz, H.B., Atreya, S.K., Brinckerhoff, W.B., Cabane, M., Coll, P., Conrad, P.G., Des Marais, D.J., Dworkin, J.P., Fairen, A.G., Francois, P., Grotzinger, J.P., Kashyap, S., ten Kate, I.L., Leshin, L.A., Malespin, C.A., Martin, M.G., Martin-Torres, F.J., McAdam, A.C., Ming, D.W., Navarro-Gonzalez, R., Pavlov, A.A., Prats, B.D., Squyres, S.W., Steele, A., Stern, J.C., Sumner, D.Y., Sutter, B., Zorzano, M.-P., the MSL Science Team, 2015. Organic molecules in the Sheepbed mudstone, Gale crater, Mars. J. Geophys. Res. - Planets 120 (3), 495-514.

Frydenvang, J., Gasda, P.J., Hurowitz, J.A., Grotzinger, J.P., Wiens, R.C., Newsom, H.E., Edgettt, K.S., Watkins, J., Bridges, J.C., Maurice, S., Fisk, M.R., Johnson, J.R., Rapin, W., Stein, N.T., Clegg, S.M., Schwenzer, S.P., Bedford, C.C., Edwards, P., Mangold, N., Cousin, A., Anderson, R.B., Payré, V., Vaniman, D., Blake, D.F., Lanza, N.L., Gupta, S., Van Beek, J., Sautter, V., Meslin, P.-Y., Rice, M., Milliken, R., Gellert, R., Thompson, L., Clark, B.C., Sumner, D.Y., Fraeman, A.A., Kinch, K.M., Madsen, M.B., Mitrofanov, I.G., Jun, I., Calef, F., Vasavada, A.R., 2017. Diagenetic silica enrichment and late-stage groundwater activity in Gale Crater, Mars. Geophys. Res. Lett. 44 (10), 4716-4724.

Frydenvang, J., Mangold, N., Wiens, R.C., Fraeman, A.A., Edgar, L.A., Fedo, C., L'Haridon, J., Gupta, S., Grotzinger, J.P., Bedford, C., Bridges, J., Clark, B.C., Rampe, E.B., Forni, O., Gasda, P.J., Lanza, N.L., Ollila, A.M., Meslin, P.-Y., Payré, V., Calef, F., Salvatore, M., 2019. The role of large-scale diagenesis in the formation of Vera Rubin Ridge in Gale crater, Mars, as implied by ChemCam observations. Lunar and Planetary Science Conference (Vol. 50).

Fukushi, K., Sekine, Y., Sakuma, H., Morida, K., Wordsworth, R., 2019. Semiarid climate and hyposaline lake on early Mars inferred from reconstructed water chemistry at Gale. Nature Comm. 10 (4896). https://doi.org/10.1038/s41467-019-12871-6.

Gasda, P.J., Haldeman, E.B., Wiens, R.C., Rapin, W., Bristow, T.F., Bridges, J.C. Schwenzer, S.P., Clark, B., Herkenhoff, K., Frydenvang, J., Lanza, N.L., Maurice, S. Clegg, S., Delapp, D.M., Sanford, V.L., Bodine, M.R., McInroy, R., 2017. In situ detection of boron by ChemCam on Mars. Geophys. Res. Lett. 44 (17), 8739-8748.

Gasda, P.J., Lanza, N., Meslin, P.-Y., Forni, O., l'Haridon, J., Fischer, W.W., Hurowitz, J., Rivera-Hernandez, F., Sumner, D.Y., Stein, N., Lamm, S.N., Ollila, O., Clark, B.C., Fairen, A.G., Newsom, H.E., Frydenvang, J., Clegg, S.M., Wiens, R.C., Maurice, S. 2019. High-Mn sandstone as evidence for oxidized conditions in Gale crater lake. Lunar and Planetary Science Conference (Vol. 50).

Gellert, R., Rieder, R., Brückner, J., Clark, B.C., Dreibus, G., Klingelhöfer, G., Lugmair, G., Ming, D.W., Wänke, H., Yen, A., Zipfel, J., Squyres, S.W., 2006. Alpha particle X-ray spectrometer (APXS): results from Gusev crater and calibration report. J. Geophys. Res. Planets 111 (E2). https://doi.org/10.1029/2005JE002555.

Getahun, A., Reed, M.H., Symonds, R., 1996. Mount St. Augustine volcano fumarole wall rock alteration: mineralogy, zoning, composition and numerical models of its formation process. J. Volcanol. Geotherm. Res. 71 (2), 73-107.

Gómez-Elvira, J., Armiens, C., Castañer, L., Domínguez, M., Genzer, M., Gómez, F., Haberle, R., Harri, A.-M., Jimenez, V., Kahanpaa, H., Kowalski, L., Lepinette, A., Martin, J., Martinez-Frias, J., McEwan, I., Mora, L., Moreno, J., Navarro, S., de Pablo, M.A., Peinado, V., Peña, A., Polkko, J., Ramos, M., Renno, N.O., Ricart, J., Richardson, M., Rodriguez-Manfredi, J., Romeral, J., Sebastian, E., Serrano, J., de la, T., Juarez, M., Torres, J., Torrero, F., Urqui, R., Vazquez, L., Velasco, T., Verdasca, J., Zorzano, M.-P., Martin-Torres, J., 2012. REMS: the environmental sensor suite for the Mars science laboratory rover. Space Sci. Rev. 170 (1-4), 583-640.

Grotzinger, J.P., Arvidson, R.E., Bell III, J.F., Calvin, W., Clark, B.C., Fike, D.A. Golombek, M., Greeley, R., Haldemann, A., Herkenhoff, K.E., Joliff, B.L., Knoll, A.H., Malin, M., McLennan, S.M., Parker, T., Soderblom, L., Sohl-Dickstein, J.N., Squyres, S.W., Tosca, N.J., Watters, W.A., 2005. Stratigraphy and sedimentology of a dry to wet eolian depositional system, Burns formation, Meridiani Planum, Mars. Earth Planet. Sci. Lett. 240 (1-2), 11-72.

Grotzinger, J.P., Crisp, J., Vasavada, A.R., Anderson, R.C., Baker, C.J., Barry, R., Blake, D.F., Conrad, P., Edgett, K.S., Ferdowski, B., Gellert, R., Gilbert, J.B., Golombek, M. Gomez-Elvira, J., Hassler, D.M., Jandura, L., Litvak, M., Mahaffy, P., Maki, J., Meyer, M., Malin, M.C., Mitrofanov, I., Simmonds, J.J., Vaniman, D., Welch, R.V., Wiens, R.C., 2012. Mars Science Laboratory mission and science investigation. Space Sci. Rev. 170 (1-4), 5-56.

Grotzinger, J.P., Sumner, D.Y., Kah, L.C., Stack, K., Gupta, S., Edgar, L., Rubin, D., Lewis, K., Schieber, J., Mangold, N., Milliken, R., Conrad, P.G., Des Marais, D., Farmer, J., Siebach, K., Calef III, F., Hurowitz, J., McLennan, S.M., Ming, D., Vaniman, D., Crisp, J., Vasavada, A., Edgett, K.S., Malin, M., Blake, D., Gellert, R., Mahaffy, P., Wiens, R.C., Maurice, S., Grant, J.A., Wilson, S., Anderson, R.C., Beegle, L., Arvidson, R., Hallet, B., Sletten, R.S., Rice, M., Bell III, J., Griffes, J., Ehlmann, B., Anderson, R.B., Bristow, T.F., Dietrich, W.E., Dromart, G., Eigenbrode, J., Fraeman, A., Hardgrove, C., Herkenhoff, K., Jandura, L., Kocurek, G., Lee, S., Leshin, L.A., Leveille, R., Limonadi, D., Maki, J., McCloskey, S., Meyer, M., Minitti, M., Newsom, H., Oehler, D., Okon, A., Palucis, M., Parker, T., Rowland, S., Schmidt, M., Squyres, S., Steele, A., Stolper, E., Summons, R., Treiman, A., Williams, R., Yingst, A., MSL Science Team, 2014. A habitable fluvio-lacustrine environment at Yellowknife Bay, Gale Crater, Mars. Science 343 (6169), 1242777.

Grotzinger, J.P., Gupta, S., Malin, M.C., Rubin, D.M., Schieber, J., Siebach, K., Sumner, D.Y., Stack, K.M., Vasavada, A.R., Arvidson, R.E., Calef III, F., Edgar, L., Fischer, W.F., Grant, J.A., Griffes, J., Kah, L.C., Lamb, M.P., Lewis, K.W., Mangold, N., Minitti, M.E., Palucis, M., Rice, M., Williams, R.M.E., Yingst, R.A., Blake, D., Blaney, D., Conrad, P., Crisp, J., Dietrich, W.E., Dromart, G., Edgett, K.S., Ewing, R.C., Gellert, R., Hurowitz, J.A., Kocurek, G., Mahaffy, P., McBride, M.J., McLennan, S.M., Mischna, M., Ming, D., Milliken, R., Newsom, H., Oehler, D., Parker, T.J., Vaniman, D., Wiens, R.C.,
Wilson, S.A., 2015. Deposition, exhumation, and paleoclimate of an ancient lake deposit, Gale crater, Mars. Science 350 (6257), aac7575.

Grotzinger, J.P., Milliken, R.E. (Eds.), 2012. Sedimentary Geology of Mars Vol 102 SEPM special publication. https://doi.org/10.2110/pec.12.102.

Hassler, D.M., Zeitlin, C., Wimmer-Schweingruber, R.F., Böttcher, S., Martin, C., Andrews, J., Böhm, E., Brinza, D.E., Bullock, M.A., Burmeister, S., Ehresmann, B., Epperly, M., Grinspoon, D., Kohler, J., Kortmann, O., Neal, K., Peterson, J., Posner, A., Rafkin, S., Seimetz, L., Smith, K.D., Tyler, Y., Weigle, G., Reitz, G., Cucinotta, F.A., 2012. The radiation assessment detector (RAD) investigation. Space Sci. Rev. 170 (1-4), 503-558.

Hausrath, E.M., Ming, D.W., Peretyazhko, T.S., Rampe, E.B., 2018. Reactive transport and mass balance modeling of the Stimson sedimentary formation and altered fracture zones constrain diagenetic conditions at Gale crater, Mars. Earth Planet. Sci. Lett. 491, 1-10.

Hoehler, T., 2007. An energy balance concept for habitability. Astrobiol 7 (6), 824-838.

Howard, A.D., Moore, J.M., Irwin III, R.P., 2005. An intense terminal epoch of widespread fluvial activity on early Mars: 1 . Valley network incision and associated deposits. J. Geophys. Res. Planets 110 (E12).

Hurowitz, J.A., Grotzinger, J.P., Fischer, W.W., McLennan, S.M., Milliken, R.E., Stein, N., Vasavada, A.R., Blake, D.F., Dehouck, E., Eigenbrode, J.L., Fairen, A.G., Frydenvang, J., Gellert, R., Grant, J.A., Gupta, S., Herkenhoff, K.E., Ming, D.W., Rampe, E.B., Schmidt, M.E., Siebach, K.L., Stack-Morgan, K., Sumner, D.Y., Wiens, R.C., 2017. Redox stratification of an ancient lake in Gale crater, Mars. Science 356 (6341) eaah6849.

Irwin, R.P., Howard, A.D., Craddock, R.A., Moore, J.M., 2005. An intense terminal epoch of widespread fluvial activity on early Mars: 2 . Increased runoff and paleolake development. J. Geophys. Res. - Planets 110 (E12).

Jakosky, B.M., Slipski, M., Benna, M., Mahaffy, P., Elrod, M., Yelle, R., Stone, S., Alsaeed, N., 2017. Mars' atmospheric history derived from upper-atmosphere measurements of ${ }^{38} \mathrm{Ar} /{ }^{36} \mathrm{Ar}$. Science 355 (6332), 1408-1410.

Johnson, J.R., Bell III, J.F., Bender, S., Blaney, D., Cloutis, E., DeFlores, L., Ehlmann, B., Gasnault, O., Gondet, B., Kinch, K., Lemmon, M., Le Mouélic, S., Maurice, S., Rice, M., Wiens, R.C., the MSL Science Team, 2015. ChemCam Passive Reflectance Spectroscopy of Surface Materials at the Curiosity Landing Site, Mars. Icarus 249, 74-92. https://doi.org/10.1016/j.icarus.2014.02.028.

Johnson, J.R., Bell III, J.F., Bender, S., Blaney, D., Cloutis, E., Ehlmann, B., Fraeman, A., Gasnault, O., Kinch, K., Le Mouélic, S., Maurice, S., Rampe, E., Vaniman, D., Wiens, R.C., 2016. Constraints on iron sulfate and iron oxide mineralogy from ChemCam visible/near-infrared reflectance spectroscopy of Mt. Sharp basal units, Gale Crater, Mars. Am. Mineral. 101, 1501-1514.

Johnson, J.R., Achilles, C., Bell III, J.F., Bender, S., Cloutis, E., Ehlmann, B., Fraeman, A., Gasnault, O., Hamilton, V.E., Le Mouélic, S., Maurice, S., Pinet, P., Thompson, L., Wellington, D., Wiens, R.C., 2017a. Visible/near-infrared spectral diversity from in situ observations of the Bagnold Dune Field sands in Gale Crater, Mars. J. Geophys. Res. 122. https://doi.org/10.1002/2016JE005187.

Johnson, J.R., Cloutis, E., Fraeman, A.A., Wiens, R.C., Maurice, S., Bender, S., Bell III, J.F., Rampe, E., 2017b. ChemCam passive reflectance spectroscopy of recent Murray formation drill tailings: Oudam, Marimba, Quela, Sebina. Lunar and Planetary Science Conference (Vol. 48).

Johnson, J.R., Bell III, J.F., Cloutis, E.A., Fraeman, A.A., Wiens, R.C., Maurice, S., 2017c Ferric oxide variability in the Murray formation from ChemCam passive reflectance observations. GSA Meeting With Abstracts (Cordilleran Section) (No. 12-1).

Kah, L.C., Kronyak, R.E., Ming, D.W., Grotzinger, J.P., Schieber, J., Sumner, D.Y., Edgett, K.S., 2015a. Diagenetic crystal growth in the Murray formation, Gale crater, Mars. Lunar and Planetary Science Conference (Vol. 46).

Kah, L.C., Kronyak, R., Van Beek, J., Nachon, M., Mangold, N., Thompson, L., Wiens, R., Grotzinger, J., Farmer, J., Minitti, M., 2015b. Diagenetic crystal clusters and dendrites, lower Mount sharp, Gale crater. Lunar and Planetary Science Conference (Vol. 46).

Kah, L.C., Stack, K., Eigenbrode, J., Yingst, R.A., Edgett, K., 2018. Implications of syndepositional calcium sulfate precipitation in Gale crater, Mars. Terra Nova 00, 1-9.

Kastner, M., Keene, J.B., Gieskes, J.M., 1977. Diagenesis of siliceous oozes - I. Chemical controls on the rate of opal-A to opal-CT transformation - an experimental study. Geochim. Cosmochim. Acta 41 (8), 1041-1051.

Kronyak, R.E., Kah, L.C., Edgett, K.S., VanBommel, S.J., Thompson, L.M., Wiens, R.C., Sun, V.Z., Nachon, M., 2019. Mineral-filled fractures as indicators of multigenerational fluid flow in the Pahrump Hills member of the Murray formation, Gale crater, Mars. Earth Space Sci. 6 (2), 238-265.

L'Haridon, J., Mangold, N., Wiens, R.C., Cousin, A., David, G., Johnson, J.R., Fraeman, A, Rapin, W., Frydenvang, J., Schwenzer, S., Bridges, J., Horgan, B., House, C., Meslin, P.-Y., Salvatore, M., Gasnault, O., Maurice, S., 2019. Iron mobility during diagenesis deduced from ChemCam observations at Gale crater, Mars. Lunar and Planetary Science Conference (Vol. 50).

Lanza, N.L., Fischer, W.W., Wiens, R.C., Grotzinger, J., Ollila, A.M., Cousin, A., Anderson, R.B., Clark, B.C., Gellert, R., Mangold, N., Maurice, S., Le Mouélic, S., Nachon, M., Schmidt, M., Berger, J., Clegg, S.M., Forni, O., Hardgrove, C., Melikechi, N., Newsom, H.E., Sautter, V., 2014. High manganese concentrations in rocks at Gale crater, Mars. Geophys. Res. Lett. 41 (16), 5755-5763.

Lanza, N.L., Wiens, R.C., Arvidson, R.E., Clark, B.C., Fischer, W.W., Gellert, R., Grotzinger, J.P., Hurowitz, J.A., McLennan, S.M., Morris, R.V., Rice, M.S., Bell III, J.F., Berger, J.A., Blaney, D.L., Bridges, N.T., Calef III, F., Campbell, J.L., Clegg, S.M., Cousin, A., Edgett, K.S., Fabre, C., Fisk, M.R., Forni, O., Frydenvang, J., Hardy, K.R., Hardgrove, C., Johnson, J.R., Lasue, J., Le Mouélic, Malin, M.C., Mangold, N., MartinTorres, J., Maurice, S., McBride, M.J., Ming, D.W., Newsom, H.E., Ollila, A.M., Sautter, V., Schröder, S., Thompson, L.M., Treiman, A.H., VanBommel, S., Vaniman, D.T., Zorzano, M.-P., 2016. Oxidation of manganese in an ancient aquifer, Kimberley 
formation, Gale crater, Mars. Geophys. Res. Lett. 43 (14), 7398-7407.

Lapotre, M.G.A., Rampe, E.B., 2018. Curiosity's investigation of the Bagnold Dunes, Gale crater: overview of the two-phase scientific campaign and introduction to the special collection. Geophys. Res. Lett. 45 (19), 10-200.

Lapotre, M.G., Ehlmann, B.L., Minson, S.E., Arvidson, R.E., Ayoub, F., Fraeman, A.A., Ewing, R.C., Bridges, N.T., 2017. Compositional variations in sands of the Bagnold Dunes, Gale crater, Mars, from visible-shortwave infrared spectroscopy and comparison with ground truth from the Curiosity rover. J. Geophys. Res. - Planets 122 (12), 2489-2509.

Lasue, J., Cousin, A., Meslin, P.-Y., Mangold, N., Wiens, R.C., Berger, G., Dehouck, E., Forni, O., Goetz, W., Gasnault, O., Rapin, W., Schroeder, S., Ollila, A., Le Mouelic, S., Maurice, S., Anderson, R., Blaney, D., Clark, B., Clegg, S.M., d’Uston, C., Fabre, C., Lanza, N., Madsen, M.B., Martin-Torres, J., Melikechi, N., Newsom, H., Sautter, V., Zorzano, M.P., 2018. Martian eolian dust probed by ChemCam. Geophys. Res. Lett. 45 (20), 10-968.

Le Deit, L., Mangold, N., Forni, O., Cousin, A., Lasue, J., Schröder, S., Wiens, R.C., Sumner, D., Fabre, C., Stack, K.M., Anderson, R.B., Blaney, D., Clegg, S., Dromart, G., Fisk, M., Gasnault, O., Grotzinger, J.P., Gupta, S., Lanza, N., Le Mouélic, S., Maurice, S., McLennan, S.M., Meslin, P.-Y., Nachon, M., Newsom, H., Payré, V., Rapin, W., Rice, M., Sautter, V., Treiman, A.H., 2016. The potassic sedimentary rocks in Gale crater, Mars, as seen by ChemCam on board Curiosity. J. Geophys. Res. - Planets 121 (5), 784-804.

Le Mouélic, S., Gasnault, O., Herkenhoff, K.E., Bridges, N.T., Langevin, Y., Mangold, N., Maurice, S., Wiens, R.C., Pinet, P., Newsom, H.E., Deen, R.G., Bell III, J.F., Johnson, J.R., Rapin, W., Barraclough, B., Blaney, D.L., Deflores, L., Maki, J., Malin, M.C., Perez, R., Saccoccio, M., 2015. The ChemCam Remote Micro-Imager at Gale crater: review of the first year of operations on Mars. Icarus 249, 93-107.

Leshin, L.A., Mahaffy, P.R., Webster, C.R., Cabane, M., Coll, P., Conrad, P.G., Archer Jr., P.D., Atreya, S.K., Brunner, A.E., Buch, A., Eigenbrode, J.L., Flesch, G.J., Franz, H.B., Freissinet, C., Glavin, D.P., McAdam, A.C., Miller, K.E., Ming, D.W., Morris, R.V., Navarro-González, R., Niles, P.B., Owen, T., Pepin, R.O., Squyres, S., Steele, A., Stern, J.C., Summons, R.E., Sumner, D.Y., Sutter, B., Szopa, C., Teinturier, S., Trainer, M.G., Wray, J.J., Grotzinger, J.P., MSL Science Team, 2013. Volatile, isotope, and organic analysis of martian fines with the Mars Curiosity rover. Science 341 (6153), 1238937.

Léveillé, R.J., Bridges, J., Wiens, R.C., Mangold, N., Cousin, A., Lanza, N., Forni, O., Ollila, A., Grotzinger, J., Clegg, S., Siebach, K., Berger, G., Clark, B., Fabre, C., Anderson, R., Gasnault, O., Blaney, D., Deflores, L., Leshin, L., Maurice, S., Newsom, H., 2014. Chemistry of fracture-filling raised ridges in Yellowknife Bay, Gale crater: window into past aqueous activity and habitability on Mars. J. Geophys. Res. - Planets 119 (11), 2398-2415.

Lewis, K.W., Peters, S., Gonter, K., Morrison, S., Schmerr, N., Vasavada, A.R., Gabriel, T., 2019. A surface gravity traverse on Mars indicates low bedrock density at Gale crater. Science 363 (6426), 535-537.

Litvak, M.L., Mitrofanov, I.G., Barmakov, Y.N., Behar, A., Bitulev, A., Bobrovnitsky, Y., Bogolubov, E.P., Boynton, W.V., Bragin, S.I., Churin, S., Grebennikov, A.S., Konovalov, A., Kozyrevl, A.S., Kurdumov, G., KrylovYu, A., Kuznetsov, P., Malakhov, A.V., Mokrousov, M.I., Ryzhkov, V.I., Sanin, A.B., Shvetsov, V.N., Smirnov, G.A., Sholeninov, S., Timoshenko, G.N., Tomilina, T.M., Tuvakin, D.V., Tretyakov, V.I., Troshin, V.S., Uvarov, A., Varenikov, A., Vostrukhin, A., 2008. The dynamic albedo of neutrons (DAN) experiment for NASA's 2009 Mars science laboratory. Astrobiology 8 (3), 605-612.

Lynch, K.L., Jackson, W.A., Rey, K., Spear, J.R., Rosenzweig, F., Munakata-Marr, J., 2019. Evidence for biotic perchlorate reduction in naturally perchlorate-rich sediments of Pilot Valley Basin, Utah. Astrobiol 19 (5), 629-641.

Mahaffy, P.R., Webster, C.R., Cabane, M., Conrad, P.G., Coll, P., Atreya, S.K., Arvey, R., Bariciniak, M., Benna, M., Bleacher, L., Brinckerhoff, W.B., Eigenbrode, J.L., Carignan, D., Cascia, M., Chalmers, R.A., Dworkin, J.P., Errigo, T., Everson, P., Franz, H., Farley, R., Feng, S., Frazier, G., Freissinet, C., Glavin, D.P., Harpold, D.N., Hawk, D., Holmes, V., Johnson, C.S., Jones, A., Jordan, P., Kellogg, J., Lewis, J., Lyness, E., Malespin, C.A., Martin, D.K., Maurer, J., McAdam, A.C., McLennan, D., Nolan, T.J., Noriega, M., Pavlov, A.A., Prats, B., Raaen, E., Sheinman, O., Sheppard, D., Smith, J., Stern, J.C., Tan, F., Trainer, M., Ming, D.W., Morris, R.V., Jones, J., Gundersen, C., Steele, A., Wray, J., Botta, O., Leshin, L.A., Owen, T., Battel, S., Jakosky, B.M., Manning, H., Squyres, S., Navarro-Gonzalez, McKay, C.P., Paulin, F., Sternberg, R., Buch, A., Sorensen, P., Kline-Schoder, R., Soscia, D., Szopa, C., Teinturier, S., Baffes, C., Feldman, J., Flesch, G., Forouhar, S., Garcia, R., Keymeulen, D., Woodward, S., Block, B.P., Arnett, K., Miller, R., Edmonson, C., Gorevan, S., Mumm, E., 2012. The sample analysis at Mars investigation and instrument suite. Space Sci. Rev. 170 (1-4), 401-478.

Mahaffy, P.R., Webster, C.R., Stern, J.C., Brunner, A.E., Atreya, S.K., Conrad, P.G., Domagal-Goldman, S., Eigenbrode, J.L., Flesch, G.J., Christensen, L.E., Franz, H.B., Freissinet, C., Glavin, D.P., Grotzinger, J.P., Jones, J.H., Leshin, L.A., Malespin, C., McAdam, A.C., Ming, D.W., Navarro-Gonzalez, R., Niles, P.B., Owen, T., Pavlov, A.A., Steele, A., Trainer, M.G., Williford, K.H., Wray, J.J., the MSL Science Team, 2015 The imprint of atmospheric evolution in the $\mathrm{D} / \mathrm{H}$ of Hesperian clay minerals on Mars. Science 347 (6220), 412-414.

Malin, M.C., Ravine, M.A., Caplinger, M.A., Ghaemi, F.T., Schaffner, J.A., Maki, J.N., Bell III, J.F., Cameron, J.F., Dietrich, W.E., Edgett, K.S., Edwards, L.J., Garvin, J.B., Hallet, B., Herkenhoff, K.E., Heydari, E., Kah, L.C., Lemmon, M.T., Minitti, M.E., Olson, T.S., Parker, T.J., Rowland, S.K., Schieber, J., Sletten, R., Sullivan, R.J., Sumner, D.Y., Yingst, S.A., Duston, B.M., McNair, S., Jensen, E.H., 2017. The mars science laboratory (MSL) mast cameras and descent imager: investigation and instrument descriptions. Earth Space Sci. 4, 506-539.

Mangold, N., Thompson, L.M., Forni, O., Williams, A.J., Fabre, C., Le Deit, L., Wiens, R.C., Williams, R., Anderson, R.B., Blaney, D.L., Calef, F., Cousin, A., Clegg, S.M., Dromart, G., Dietrich, W.E., Edgett, K.S., Fisk, M.R., Gasnault, O., Gellert, R., Grotzinger, J.P.,
Kah, L., Le Mouélic, S., McLennan, S.M., Maurice, S., Meslin, P.-Y., Newsom, H.E., Palucis, M.C., Rapin, W., Sautter, V., Siebach, K.L., Stack, K., Sumner, D., Yingst, A., 2016. Composition of conglomerates analyzed by the Curiosity rover: implications for Gale crater crust and sediment sources. J. Geophys. Res. - Planets 121 (3), 353-387.

Mangold, N., Dehouck, E., Fedo, C., Forni, O., Achilles, C., Bristow, T., Downs, R.T., Frydenvang, J., Gasnault, O., L'Haridon, J., Le Deit, L., Maurice, S., McLennan, S.L., Meslin, P.-Y., Morrison, S., Newsom, H.E., Rampe, E., Rapin, W., Rivera-Hernandez, F., Salvatore, M., Wiens, R.C., 2019. Chemical alteration of fine-grained sedimentary rocks at Gale crater. Icarus 321, 619-631.

Martin, P.E., Farley, K.A., Baker, M.B., Malespin, C.A., Schwenzer, S.P., Cohen, B.A. Mahaffy, P.R., McAdam, A.C., Ming, D.W., Vasconcelos, P.M., Navarro-González, R., 2017. A two-step K-Ar experiment on mars: dating the diagenetic formation of jarosite from amazonian groundwaters. J. Geophys. Res. - Planets 122 (12), 2803-2818.

Matsumoto, G., Torii, T., Hanya, T., 1984. Vertical distribution of organic constituents in an Antarctic lake: Lake Vanda. Hydrobiol 111, 119-126.

Matsumoto, G.I., Watanuki, K., Torii, T., 1989. Vertical distribution of organic constituents in an Antarctic lake: Lake Fryxell. Hydrobiol 172, 291-303.

Maurice, S., Wiens, R.C., Saccoccio, M., Barraclough, B., Gasnault, O., Forni, O., Mangold, N., Baratoux, D., Bender, S., Berger, G., Bernardin, J., Berthé, M., Bridges, N., Blaney, D., Bouyé, M., Cais, P., Clark, B., Clegg, S., Cousin, A., Cremers, D., Cros, A., DeFlores, L., Derycke, C., Dingler, B., Dromart, G., Dubois, B., Dupieux, M., Durand, E., d'Uston, L., Fabre, C., Fabre, B., Gaboriaud, A., Gharsa, T., Herkenhoff, K., Kan, E., Kirkland, L., Kaouach, D., Lacour, J.-L., Langevin, Y., Lasue, J., Le Mouélic, S., Lescure, M., Lewin, E., Limonadi, D., Manhes, G., Mauchien, P., McKay, C., Meslin, P.-Y., Michel, Y., Miller, E., Newsom, H.E., Orttner, G., Paillet, P., Parès, L., Parot, Y., Pérez, R., Pinet, P., Poitrasson, F., Quertier, B., Sallé, B., Sotin, C., Sautter, V., Séran, H., Simmonds, J.J., Sirven, J.-B., Stiglich, R., Striebig, N., Thocaven, J.-J., Toplis, M.J., Vaniman, D., 2012. The ChemCam instrument suite on the Mars Science Laboratory (MSL) rover: science objectives and mast unit description. Space Sci. Rev. 170 (1-4), 95-166.

Maurice, S., Clegg, S.M., Wiens, R.C., Gasnault, O., Rapin, W., Forni, O., Cousin, A., Sautter, V., Mangold, N., Le Deit, L., Nachon, M., Anderson, R.B., Lanza, N.L., Fabre, C., Payré, V., Lasue, J., Meslin, P.-Y., Leveille, R.J., Barraclough, B.L., Beck, P., Bender, S.C., Berger, G., Bridges, J.C., Bridges, N.T., Dromart, G., Dyar, M.D., Francis, R., Frydenvang, J., Gondet, B., Ehlmann, B.L., Herkenhoff, K.E., Johnson, J.R., Langevin, Y., Madsen, M.B., Melikechi, N., Lacour, J.-L., Le Mouélic, S., Lewin, E., Newsom, H.E., Ollila, A.M., Pinet, P., Schröder, S., Sirven, J.-B., Tokar, R.L., Toplis, M.J., d'Uston, C., Vaniman, D.T., Vasavada, A.R., 2016. ChemCam activities and discoveries during the nominal mission of the Mars Science Laboratory in Gale crater, Mars. J. Anal. At. Spectrom. https://doi.org/10.1039/c5ja00417a.

McAdam, A.C., Franz, H.B., Sutter, B., Archer Jr., P.A., Freissinet, C., Eigenbrode, J.L Ming, D.W., Atreya, S.K., Bish, D.L., Blake, D.F., Bower, H., Brunner, A., Buch, A., Glavin, D.P., Grotzinger, J.P., Mahaffy, P.R., McLennan, S.M., Morris, R.V., NavarroGonzález, R., Rampe, E.B., Squyres, S.W., Steele, A., Stern, J.C., Sumner, D.Y., Wray, J.J., 2014. Sulfur-bearing phases detected by evolved gas analysis of the Rocknest aeolian deposit, Gale crater, Mars. J. Geophys. Res. Planets 119, 373-393.

McLennan, S.M., 2003. Sedimentary silica on Mars. Geology 31 (4), 315-318.

McLennan, S.M., Bell III, J.F., Calvin, W., Christensen, P.R., Clark, B.C., De Souza Jr., P.A., Farmer, J., Farrand, W.H., Fike, D.A., Gellert, R., Ghosh, A., Glotch, T.D., Grotzinger, J.P., Hahn, B., Herkenhoff, K.E., Hurowitz, J.A., Johnson, J.R., Johnson, S.S., Joliff, B., Klingelhöfer, G., Knoll, A.H., Learner, Z., Malin, M.C., McSween Jr., H.Y., Pocock, J., Ruff, S.W., Soderblom, L.A., Squyres, S.W., Tosca, N.J., Watters, W.A., Wyatt, M.B., Yen, A., 2005. Provenance and diagenesis of the evaporite-bearing Burns formation, Meridiani Planum, Mars. Earth Planet. Sci. Lett. 240 (1-2), 95-121.

McLennan, S.M., Anderson, R.B., Bell III, J.F., Bridges, J.C., Calef, F., Campbell, J.L., Clark, B.C., Clegg, S., Conrad, P., Cousin, A., Des Marais, D.J., Dromart, G., Dyar, M.D., Edgar, L.A., Ehlmann, B.L., Fabre, C., Forni, O., Gasnault, O., Gellert, R., Gordon, S., Grant, J.A., Grotzinger, J.P., Gupta, S., Herkenhoff, K.E., Hurowitz, J.A., King, P.L., Le Mouélic, S., Leshin, L.A., Léveillé, R., Lewis, K.W., Mangold, N., Maurice, S., Ming, D.W., Morris, R.V., Nachon, M., Newsom, H.E., Ollila, A.M., Perrett, G.M., Rice, M.S., Schmidt, M.E., Schwenzer, S.P., Stack, K., Stolper, E.M., Sumner, D.Y., Treiman, A.H., VanBommel, S., Vaniman, D.T., Vasavada, A., Wiens, R.C., 2014. Elemental geochemistry of sedimentary rocks at Yellowknife Bay, Gale crater, Mars. Science 343 (6169), 1244734.

Meslin, P.Y., Gasnault, O., Forni, O., Schröder, S., Cousin, A., Berger, G., Clegg, S.M., Lasue, J., Sautter, V., Le Mouélic, S., Wiens, R.C., Fabre, C., Goetz, W., Bish, D., Mangold, N., Ehlmann, B., Lanza, N., Harri, A.-M., Anderson, R., Rampe, E. McConnochie, T.H., Pinet, P., Blaney, D., Leveille, R., Archer, D., Barraclough, B., Bender, S., Blake, D., Blank, J.G., Bridges, N., Clark, B.C., DeFlores, L., Delapp, D., Dromart, G., Dyar, M.D., Fisk, M., Gondet, B., Grotzinger, J., Herkenhoff, K., Johnson, J., Lacour, J.-L., Langevin, Y., Leshin, L., Lewin, E., Madsen, M.B., Melikechi, N., Mezzacappa, A., Mischna, M.A., Moores, J.E., Newsom, H., Ollila, A., Perez, R., Renno, N., Sirven, J.-B., Tokar, R., de la Torre, M., d'Uston, L., Vaniman, D., Yingst, A., MSL Science Team, 2013. Soil diversity and hydration as observed by ChemCam at Gale crater, Mars. Science 341 (6153), 1238670.

Milliken, R.E., Grotzinger, J.P., Thomson, B.J., 2010. Paleoclimate of Mars as captured by the stratigraphic record in Gale crater. Geophys. Res. Lett. 37 (4).

Ming, D.W., Mumpton, F.A., 1989. Zeolites in soils. In: Dixon, J.B., Weed, S.B. (Eds.), Minerals in Soil Environments, 2nd ed. SSSA Book Ser. 1. SSSA, Madison, WI, pp. 873-911.

Ming, D.W., Gellert, R., Morris, R.V., Arvidson, R.E., Brueckner, J., Clark, B.C., Cohen, B.A., d’Uston, C., Economou, T., Fleischer, I., Klingelhöfer, G., McCoy, T.J., Mittlefehldt, D.W., Schmidt, M.E., Schröder, C., Squyres, S.W., Tréguier, E., Yen, A.S., Zipfel, J., 2008. Geochemical properties of rocks and soils in Gusev crater, mars: results of the alpha particle X-ray spectrometer from Cumberland Ridge to home plate. J. Geophys. Res. - Planets 113 (E12). 
Ming, D.W., Archer Jr., P.D., Glavin, D.P., Eigenbrode, J.L., Franz, H.B., Sutter, B., Brunner, A.E., Stern, J.C., Freissinet, C., McAdam, A.C., Mahaffy, P.R., Cabane, M. Coll, P., Campbell, J.L., Atreya, S.K., Niles, P.B., Bell III, J.F., Bish, D.L., Brinckerhoff, W.B., Buch, A., Conrad, P.G., Des Marais, D.J., Ehlmann, B.L., Fairén, A.G., Farley, K., Flesch, G.J., Francois, P., Gellert, R., Grant, J.A., Grotzinger, J.P., Gupta, S., Herkenhoff, K.E., Hurowitz, J.A., Leshin, L.A., Lewis, K.W., McLennan, S.M., Miller, K.E., Moersch, J., Morris, R.V., Navarro-González, R., Pavlov, A.A., Perrett, G.M., Pradler, I., Squyres, S.W., Summons, R.E., Steele, A., Stolper, E.M., Sumner, D.Y., Szopa, C., Teinturier, S., Trainer, M.G., Treiman, A.H., Vaniman, D.T., Vasavada, A.R., Webster, C.R., Wray, J.J., Yingst, R.A., MSL Science Team, 2014. Volatile and organic compositions of sedimentary rocks in Yellowknife Bay, Gale Crater, Mars. Science 343 (6169), 1245267.

Mloszewska, A.M., Pecoits, E., Cates, N.L., Mojzsis, S.J., O'Neil, J., Robbins, L.J. Konhauser, K.O., 2012. The composition of Earth's oldest iron formations: the Nuvvuagittuq Supracrustal Belt (Québec, Canada). Earth Planet. Sci. Lett. 317, $331-342$

Morris, R.V., Klingelhoefer, G., Schröder, C., Rodionov, D.S., Yen, A., Ming, D.W., de Souza Jr., P.A., Wdowiak, T., Fleischer, I., Gellert, R., Bernhardt, B., Bonnes, U., Cohen, B.A., Evlanov, E.N., Foh, J., Gütlich, P., Kankeleit, E., McCoy, T., Mittlefehldt, D.W., Renz, F., Schmidt, M.E., Zubkov, B., Squyres, S.W., Arvidson, R.E., 2006. Mössbauer mineralogy of rock, soil, and dust at Meridiani Planum, Mars: opportunity's journey across sulfate-rich outcrop, basaltic sand and dust, and hematite lag deposits. J. Geophys. Res. - Planets 111 (E12).

Morris, R.V., Klingelhoefer, G., Schröder, C., Fleischer, I., Ming, D.W., Yen, A.S., Gellert, R., Arvidson, R.E., Rodionov, D.S., Crumpler, L.S., Clark, B.C., Cohen, B.A., McCoy, T.J., Mittlefehldt, D.W., Schmidt, M.E., de Souza Jr., P.A., Squyres, S.W., 2008. Iron mineralogy and aqueous alteration from Husband Hill through home plate at Gusev crater, Mars: results from the Mössbauer instrument on the spirit mars exploration rover. J. Geophys. Res. - Planets 113 (E12).

Morris, R.V., Ming, D.W., Blake, D.F., Vaniman, D.T., Bish, D.L., Chipera, S.J., Downs, R.T., Gellert, R., Treiman, A.H., Yen, A.S., Achilles, C.N., Anderson, R.C., Bristow, T.F., Crisp, J.A., Des Marais, D.J., Farmer, J.D., Grotzinger, J.P., Leshin, L.A., McAdam, A.C., Morookian, J.M., Morrison, S.M., Rampe, E.B., Sarrazin, P.C., Spanovich, N., Stolper, E.M., the MSL Science Team, 2013. The amorphous component in martian basaltic soil in global perspective from MSL and MER missions. Lunar and Planetary Science Conference (Vol. 44).

Morris, R.V., Rampe, E.B., Graff, T.G., Archer Jr., P.D., Le, L., Ming, D.W., Sutter, B., 2015. Transmission X-ray diffraction (XRD) patterns relevant to the MSL CheMin amorphous component: sulfates and silicates. Lunar and Planetary Science Conference (Vol. 46).

Morris, R.V., Vaniman, D.T., Blake, D.F., Gellert, R., Chipera, S.J., Rampe, E.B., Ming, D.W., Morrison, S.M., Downs, R.T., Treiman, A.H., Yen, A.S., Grotzinger, J.P., Achilles, C.N., Bristow, T.F., Crisp, J.A., Des Marais, D.J., Farmer, J.D., Fendrich, K.V., Frydenvang, J., Graff, T.G., Morookian, J.M., Stolper, E.M., Schwenzer, S.P., 2016. Silicic volcanism on Mars evidenced by tridymite in high- $\mathrm{SiO}_{2}$ sedimentary rock at Gale crater. P. Natl. Acad. Sci. 113 (26), 7071-7076.

Morris, R.V., Bristow, T.F., Rampe, E.B., Yen, A.S., Vaniman, D.T., Tu, V., Thorpe, M.T. Peretyazhko, T.S., Morrison, S.M., Ming, D.W., Hazen, R.M., Downs, R.T., Downs, G.W., Des Marais, D.J., Craig, P.I., Chipera, S.J., Castle, N., Blake, D.F., Achilles, C.N., 2019. Mineralogy and formation processes for the Vera Rubin Ridge at Gale crater, Mars from CheMin and XRD analyses. Lunar and Planetary Science Conference (Vol. 50).

Morris, R., Rampe, E., Vaniman, D., Christoffersen, R., Yen, A., Morrison, S., Ming, D., Achilles, C., Fraeman, A., Le, L., Tu, V., Ott, J., Treiman, A., Hogancamp, J., Graff, T., Adams, M., Hamilton, J., Mertzman, S., Bristow, T., Blake, D., Castle, N., Chipera, S., Craig, P., Des Marais, D., Downs, G., Downs, R., Hazen, R., Morookian, J., Thorpe, M., 2020. Hydrothermal precipitation of sanidine (adularia) having full Al,Si structural disorder and specular hematite at Maunakea volcano (Hawai'i) and at Gale crater (Mars). J. Geophys. Res. Planets Submitted for publication.

Morrison, S.M., Downs, R.T., Blake, D.F., Prabhu, A.E., Vaniman, D.T., Ming, D.W., Rampe, E.B., Hazen, R.M., Achilles, C.N., Treiman, A.H., Yen, A.S., Morris, R.V., Bristow, T.F., Chipera, S.J., Sarrazin, P.C., Fendrich, K.V., Morookian, J.M., Farmer, J.D., Des Marais, D.J., Craig, P.I., 2018a. Relationships between unit-cell parameters and composition for rock-forming minerals on Earth, Mars, and other extraterrestrial bodies. Am. Mineral. 103 (6), 848-856.

Morrison, S.M., Downs, R.T., Blake, D.F., Vaniman, D.T., Ming, D.W., Hazen, R.M., Treiman, A.H., Achilles, C.N., Yen, A.S., Morris, R.V., Rampe, E.B., Bristow, T.F., Chipera, S.J., Sarrazin, P.C., Gellert, R., Fendrich, K.V., Morookian, J.M., Farmer, J.D., Des Marais, D.J., Craig, P.I., 2018b. Crystal chemistry of martian minerals from Bradbury Landing through Naukluft Plateau, Gale crater, Mars. Am. Mineral. 103 (6), 857-871.

Nachon, M., Clegg, S.M., Mangold, N., Schröder, S., Kah, L.C., Dromart, G., Ollila, A., Johnson, J.R., Oehler, D.Z., Bridges, J.C., Le Mouélic, S., Forni, O., Wiens, R.C., Anderson, R.B., Blaney, D.L., Bell III, J.F., Clark, B., Cousin, A., Dyar, M.D., Ehlmann, B., Fabre, C., Gasnault, O., Grotzinger, J., Lasue, J., Lewin, E., Léveillé, R., McLennan, S., Maurice, S., Meslin, P.-Y., Rapin, W., Rice, M., Squyres, S.W., Stack, K., Sumner, D.Y., Vaniman, D., Wellington, D., 2014. Calcium sulfate veins characterized by ChemCam/Curiosity at Gale crater, Mars. J. Geophys. Res. - Planets 119 (9), 1991-2016.

Nachon, M., Mangold, N., Forni, O., Kah, L.C., Cousin, A., Wiens, R.C., Anderson, R., Blaney, D., Blank, J.G., Calef, F., Clegg, S.M., Fabre, C., Fisk, M.R., Gasnault, O., Grotzinger, J.P., Kronyak, R., Lanza, N.L., Lasue, J., Le Deit, L., Le Mouélic, S., Maurice, S., Meslin, P.-Y., Oehler, D.Z., Payré, V., Rapin, W., Schröder, S., Stack, K., Sumner, D., 2017. Chemistry of diagenetic features analyzed by ChemCam at Pahrump Hills, Gale crater, Mars. Icarus 281, 121-136.

Nozawa-Inoue, M., Jien, M., Hamilton, N.S., Stewart, V., Scow, K.M., Hristova, K.R.,
2008. Quantitative detection of perchlorate-reducing bacteria by real-time PCR targeting the perchlorate reductase gene. Appl. Environ. Microb. 74 (6), 1941-1944.

O'Connell-Cooper, C.D., Spray, J.G., Thompson, L.M., Gellert, R., Berger, J.A., Boyd, N.I., DeSouza, E.D., Perrett, G.M., Schmidt, M., VanBommel, S.J., 2017. APXS-derived chemistry of the Bagnold dune sands: comparisons with Gale crater soils and the global Martian average. J. Geophys. Res. Planets 122 (12), 2623-2643.

O'Connell-Cooper, C.D., Thompson, L.M., Spray, J.G., Berger, J.A., VanBommel, S.J., Gellert, R., Boyd, N.I., DeSouza, E., 2018. Chemical diversity of sands within the linear and barchan dunes of the Bagnold Dunes, Gale crater, as revealed by APXS onboard Curiosity. Geophys. Res. Lett. 45 (18), 9460-9470.

Okeke, B.C., Giblin, T., Frankenberger Jr., W.T., 2002. Reduction of perchlorate and nitrate by salt tolerant bacteria. Environ. Pollut. 118 (3), 357-363.

Ott, J.P., Rampe, E.B., Morris, R.V., Treiman, A.H., 2019. Chemistry and crystallography of diagenetic, authigenic, and igneous potassium feldspar: implications for sedimentary petrology in Gale crater, Mars. Lunar and Planetary Science Conference (Vol. 50).

Peret, L., Gasnault, O., Dingler, R., Langevin, Y., Bender, S., Blaney, D., Clegg, S., Clewans, C., Delapp, D., Donny, C.M., Johnstone, S., Little, C., Lorigny, E., McInroy, R., Maurice, S., Mittal, N., Pavri, B., Perez, R., Wiens, R.C., Yana, C., 2016. Restoration of the autofocus capability of the ChemCam instrument onboard the Curiosity rover. 14th International Conference on Space Operations 2539.

Post, J.E., Bish, D.L., 1989. Rietveld refinement of crystal structures using powder X-ray diffraction data. Modern Powder Diffraction 20, 277-308.

Rampe, E.B., Morris, R.V., Archer Jr., P.D., Agresti, D.G., Ming, D.W., 2016. Recognizing sulfate and phosphate complexes chemisorbed onto nanophase weathering products on Mars using in-situ and remote observations. Am. Mineral. 101 (3), 678-689.

Rampe, E.B., Ming, D.W., Blake, D.F., Bristow, T.F., Chipera, S.J., Grotzinger, J.P., Morris, R.V., Morrison, S.M., Vaniman, D.T., Yen, A.S., Achilles, C.N., Craig, P.I., Des Marais, D.J., Downs, R.T., Farmer, J.D., Fendrich, K.V., Gellert, R., Hazen, R.M., Kah, L.C., Morookian, J.M., Peretyazhko, T.S., Sarrazin, P., Treiman, A.H., Berger, J.A., Eigenbrode, J., Fairén, A.G., Forni, O., Gupta, S., Hurowitz, J.A., Lanza, N.L., Schmidt, M.E., Siebach, K., Sutter, B., Thompson, L.M., 2017. Mineralogy of an ancient lacustrine mudstone succession from the Murray formation, Gale crater, Mars. Earth Planet. Sci. Lett. 471, 172-185.

Rampe, E.B., Lapotre, M.G.A., Bristow, T.F., Arvidson, R.E., Morris, R.V., Achilles, C.N., Weitz, C., Blake, D.F., Ming, D.W., Morrison, S.M., Vaniman, D.T., Chipera, S.J., Downs, R.T., Grotzinger, J.P., Hazen, R.M., Peretyazhko, T.S., Sutter, B., Tu, V., Yen, A.S., Horgan, B., Castle, N., Craig, P.I., Des Marais, D.J., Farmer, J.D., Gellert, R., McAdam, A.C., Morookian, J.M., Sarrazin, P., Treiman, A.H., 2018. Sand mineralogy within the Bagnold Dunes, Gale crater, as observed in situ and from orbit. Geophys. Res. Lett. 45 (18), 9488-9497.

Rampe, E.B., Bristow, T.F., Morris, R.V., Morrison, S.M., Achilles, C.N., Ming, D.W., Vaniman, D.T., Blake, D.F., Tu, V.M., Chipera, S.J., Yen, A.S., Peretyazhko, T.S. Downs, R.T., Hazen, R.M., Treiman, A.H., Grotzinger, J.P., Castle, N., Craig, P.I., Des Marais, D.J., Thorpe, M.T., Walroth, R.C., Downs, G.W., Fraeman, A.A., Siebach, K.L., Gellert, R., McAdam, A.C., Meslin, P.-Y., Sutter, B., Salvatore, M.R., 2020. Mineralogy of Vera Rubin Ridge from the Mars Science Laboratory CheMin Instrument. J. Geophys. Res. Planets Submitted for publication.

Rapin, W., Meslin, P.-Y., Maurice, S., Vaniman, D., Nachon, M., Mangold, N., Schröder, S., Gasnault, O., Forni, O., Wiens, R.C., Martínez, G.M., Cousin, A., Sautter, V., Lasue, J., Rampe, E.B., Archer, D., 2016. Hydration state of calcium sulfates in Gale crater, Mars: identification of bassanite veins. Earth Planet. Sci. Lett. 452, 197-205.

Rapin, W., Chauviré, B., Gabriel, T.S.J., McAdam, A.C., Ehlmann, B.L., Hardgrove, C., Meslin, P.-Y., Rondeau, B., Dehouck, E., Franz, H.B., Mangold, N., Chipera, S.J., Wiens, R.C., Frydenvang, J., Schröder, S., 2018. In situ analysis of opal in Gale crater, Mars. J. Geophys. Res. - Planets 123 (8), 1955-1972.

Rapin, W., Ehlmann, B.L., Dromart, G., Schieber, J., Thomas, N.H., Fischer, W.W., Fox, V.K., Stein, N.T., Nachon, M., Clark, B.C., Kah, L.C., Thompson, L.C., Meyer, H.A., Gabriel, T.S.J., Hardgrove, C., Mangold, N., Rivera-Hernandez, F., Wiens, R.C., Vasavada, A.R., 2019. An interval of high salinity in ancient Gale crater lake on Mars. Nat. Geosci. 12, 889-895.

Rice, M.S., Gupta, S., Treiman, A.H., Stack, K.M., Calef, F., Edgar, L.A., Grotzinger, J. Lanza, N., Le Deit, L., Lasue, J., Siebach, K.L., Vasavada, A., Wiens, R.C., Williams, J., 2017. Geologic overview of the Mars Science Laboratory rover mission at the Kimberley, Gale crater, Mars. J. Geophys. Res. - Planets 122 (1), 2-20.

Rietveld, H., 1969. A profile refinement method for nuclear and magnetic structures. J. Appl. Crystallogr. 2 (2), 65-71.

Rubin, D.M., Fairén, A.G., Martínez-Frías, J., Frydenvang, J., Gasnault, O., Gelfenbaum, G., Goetz, W., Grotzinger, J.P., Le Mouélic, S., Mangold, N., Newsom, H., Oehler, D.Z., Rapin, W., Schieber, J., Wiens, R.C., 2017. Fluidized-sediment pipes in Gale crater, Mars, and possible Earth analogs. Geology 45 (1), 7-10.

Rudolph, A., Horgan, B., Bennett, K., Rice, M., 2019. Sources of sand in Mt. Sharp: possible volcanic layers in Gale crater, Mars. Lunar and Planetary Science Conference (Vol. 50).

Sautter, V., Fabre, C., Forni, O., Toplis, M.J., Cousin, A., Ollila, A.M., Melsin, P.-Y., Maurice, S., Wiens, R.C., Baratoux, D., Mangold, N., Le Mouélic, S., Gasnault, O., Berger, G., Lasue, J., Anderson, R.A., Lewin, E., Schmidt, M., Dyar, D., Ehlmann, B.L., Bridges, J., Clark, B., Pinet, P., 2014. Igneous mineralogy at bradbury rise: the first ChemCam campaign at Gale crater. J. Geophys. Res. - Planets 119 (1), 30-46.

Sautter, V., Toplis, M.J., Wiens, R.C., Cousin, A., Fabre, C., Gasnault, O., Maurice, S., Forni, O., Lasue, J., Ollila, A., Bridges, J.C., Mangold, N., Le Mouélic, S., Fisk, M. Meslin, P.-Y., Beck, P., Pinet, P., Rapin, W., Stolper, E.M., Newsom, H., Dyar, D., Lanza, N., Vaniman, D., Clegg, S., Wray, J.J., 2015. In situ evidence for continental crust on early Mars. Nat. Geosci. 8 (8), 605.

Schieber, J., Bish, D., Coleman, M., Reed, M., Hausrath, E.M., Cosgrove, J., Gupta, S., Minitti, M.E., Edgett, K.S., Malin, M., 2017. Encounters with an unearthly mudstone: 
understanding the first mudstone found on Mars. Sedimentology 64 (2), 311-358.

Schwenzer, S.P., Bridges, J.C., Wiens, R.C., Conrad, P.G., Kelley, S.P., Leveille, R., Mangold, N., Martín-Torres, J., McAdam, A., Newsom, H., Zorzano, M.P., Rapin, W., Spray, J., Treiman, A.H., Westall, F., Fairén, A.G., Meslin, P.-Y., 2016. Fluids during diagenesis and sulfate vein formation in sediments at Gale Crater, Mars. Meteorit. Planet. Sci. 51, 2175-2202.

Schwertmann, U., Cornell, R.M., 2000. Iron Oxides in the Laboratory: Preparation and Characterization. John Wiley \& Sons.

Seelos, K.D., Seelos, F.P., Viviano-Beck, C.E., Murchie, S.L., Arvidson, R.E., Ehlmann, B.L., Fraeman, A.A., 2014. Mineralogy of the MSL Curiosity landing site in Gale crater as observed by MRO/CRISM. Geophys. Res. Lett. 41 (14), 4880-4887.

Siebach, K.L., Grotzinger, J.P., Kah, L.C., Stack, K.M., Malin, M., Léveillé, R., Sumner, D.Y., 2014. Subaqueous shrinkage cracks in the Sheepbed mudstone: Implications for early fluid diagenesis, Gale crater, Mars. J. Geophys. Res. - Planets 119 (7), 1597-1613.

Siebach, K.L., Baker, M.B., Grotzinger, J.P., McLennan, S.M., Gellert, R., Thompson, L.M., Hurowitz, J.A., 2017. Sorting out compositional trends in sedimentary rocks of the Bradbury group (Aeolis Palus), Gale crater, Mars. J. Geophys. Res. - Planets 122 (2), 295-328.

Smith, M.R., Bandfield, J.L., 2012. Geology of quartz and hydrated silica-bearing deposits near Antoniadi Crater, Mars. J. Geophys. Res. - Planets 117 (E6).

Smith, R.J., Rampe, E.B., Horgan, B.H.N., Dehouck, E., 2018. Deriving amorphous component abundance and composition of rocks and sediments on Earth and Mars. J. Geophys. Res. - Planets 123, 2485-2505.

Squyres, S.W., Knoll, A.H., 2005. Sedimentary rocks at Meridiani Planum: origin, diagenesis, and implications for life on Mars. Earth Planet. Sci. Lett. 240 (1), 1-10.

Squyres, S.W., Arvidson, R.E., Ruff, S., Gellert, R., Morris, R.V., Ming, L., D.W, Crumpler, L., Farmer, J.D., Yen, A., McLennan, S.M., Calvin, W., Bell III, J.F., Clark, B.C., Wang, A., McCoy, T.J., Schmidt, M.E., de Souza Jr., P.A., 2008. Detection of silica-rich deposits on Mars. Science 320 (5879), 1063-1067.

Stack, K.M., Grotzinger, J.P., Kah, L.C., Schmidt, M.E., Mangold, N., Edgett, K.S., Sumner, D.Y., Siebach, K.L., Nachon, M., Lee, R., Blaney, D.L., Deflores, L.P., Edgar, L.A., Fairén, A.G., Leshin, L.A., Maurice, S., Oehler, D.Z., Rice, M.S., Wiens, R.C., 2014 Diagenetic origin of nodules in the Sheepbed member, Yellowknife Bay formation, Gale crater, Mars. J. Geophys. Res. - Planets 119 (7), 1637-1664.

Stack, K.M., Grotzinger, J.P., Lamb, M.P., Gupta, S., Rubin, D.M., Kah, L.C., Edgar, L.A., Fey, D.M., Hurowitz, J.A., McBride, M., Rivera-Hernández, F., Sumner, D.Y., Van Beek, J.K., Williams, R.M.E., Yingst, R.A., 2018. Evidence for plunging river plume deposits in the Pahrump Hills member of the Murray formation, Gale crater, Mars. Sedimentology 66 (5), 1768-1802. https://doi.org/10.1111/sed.12558.

Stein, N., Grotzinger, J.P., Schieber, J., Mangold, N., Hallet, B., Newsom, H., Stack, K.M., Berger, J.A., Thompson, L., Siebach, K.L., Cousin, A., Le Mouélic, S., Minitti, M., Sumner, D.Y., Fedo, C., House, C.H., Gupta, S., Vasavada, A.R., Gellert, R., Wiens, R.C., Frydenvang, J., Forni, O., Meslin, P.-Y., Payré, V., Dehouck, E., 2018. Desiccation cracks provide evidence of lake drying on Mars, Sutton Island member, Murray formation, Gale crater. Geology 46 (6), 515-518.

Stern, J.C., Sutter, B., Freissinet, C., Navarro-González, R., McKay, C.P., Archer Jr., P.D., Buch, A., Brunner, A.E., Coll, P., Eigenbrode, J.L., Fairen, A.G., Franz, H.B., Glavin, D.P., Kashyap, S., McAdam, A.C., Ming, D.W., Steele, A., Szopa, C., Wray, J.J., Martín-Torres, F.J., Zorzano, M.-P., Conrad, P.G., Mahaffy, P.R., the MSL Science Team, 2015. Evidence for indigenous nitrogen in sedimentary and aeolian deposits from the Curiosity rover investigations at Gale crater, Mars. P. Natl. Acad. Sci 112 (14), 4245-4250.

Stolper, E.M., Baker, M.B., Newcombe, M.E., Schmidt, M.E., Treiman, A.H., Cousin, A., Dyar, M.D., Fisk, M.R., Gellert, R., King, P.L., Leshin, L., Maurice, S., McLennan, S.M., Minitti, M.E., Perrett, G., Rowland, S., Sautter, V., Wiens, R.C., Science Team, M.S.L., 2013. The petrochemistry of Jake_M: A Martian Mugearite. Science 341 (6153), 1239463.

Sun, V.Z., Stack, K.M., Kah, L.C., Thompson, L., Fischer, W., Williams, A.J., Johnson, S.S., Wiens, R.C., Kronyak, R.E., Nachon, M., House, C.H., VanBommel, S., 2019. Latestage diagenetic concretions in the Murray formation, Gale crater, Mars. Icarus 321, 866-890.

Sutter, B., Mcadam, A.C., Mahaffy, P.R., Ming, D.W., Edgett, K.S., Rampe, E.B., Eigenbrode, J.L., Franz, H.B., Freissinet, C., Grotzinger, J.P., Steele, A., House, C.H., Archer, P.D., Malespin, C.A., Navarro-González, R., Stern, J.C., Bell, J.F., Calef, F.J., Gellert, R., Glavin, D.P., Thompson, L.M., Yen, A.S., 2017. Evolved gas analyses of sedimentary rocks and eolian sediment in Gale crater, Mars: results of the Curiosity rover's sample analysis at Mars instrument from Yellowknife Bay to the Namib Dune. J. Geophys. Res. - Planets 122 (12), 2574-2609.

Taylor, S.R., McLennan, S., 2009. . Planetary Crusts: Their Composition, Origin and Evolution Vol. 10 Cambridge University Press.

Thomas, N.H., Ehlmann, B.L., Meslin, P.-Y., Rapin, W., Anderson, D.E., Rivera-Hernández, F., Wiens, R.C., 2019. Mars Science Laboratory observations of chloride salts in Gale crater, Mars. Geophys. Res. Lett. 46. https://doi.org/10.1029/2019GL082764.

Thompson, L.M., Fraeman, A.A., Berger, J.A., Boyd, N.I., Desouza, E., Gellert, R., O'Connell-Cooper, C., Spray, J.G., Yen, A.S., 2018. APXS determined chemistry of the Vera Rubin (Hematite) Ridge, Gale crater, Mars: implications for Hematite signature origin. Lunar and Planetary Science Conference (Vol. 49).

Thompson, L.M., Fraeman, A.A., Berger, J.A., Rampe, E.B., Boyd, N.I., Gellert, R., O'Connell-Cooper, C., Spray, J.G., VanBommel, S., Wilhelm, B., Yen, A., 2019. Compositional characteristics and trends withing the Vera Rubin Ridge, Gale crater, Mars as determined by APXS: sedimentary, diagenetic and alteration history. Lunar and Planetary Science Conference (Vol. 50).

Thomson, B.J., Bridges, N.T., Milliken, R., Baldridge, A., Hook, S.J., Crowley, J.K., Marion, G.M., de Souza Filho, C.R., Brown, A.J., Weitz, C.M., 2011. Constraints on the origin and evolution of the layered mound in Gale crater, Mars using Mars
Reconnaissance Orbiter data. Icarus 214 (2), 413-432.

Tosca, N.J., Knoll, A.H., 2009. Juvenile chemical sediments and the long term persistence of water at the surface of Mars. Earth Planet. Sci. Lett. 286 (3-4), 379-386.

Tosca, N.J., Ahmed, I.A., Tutolo, B.M., Ashpitel, A., Hurowitz, J.A., 2018. Magnetite authigenesis and the warming of early Mars. Nat. Geosci. 11 (9), 635.

Treiman, A.H., Morris, R.V., Agresti, D.G., Graff, T.G., Achilles, C.N., Rampe, E.B., Bristow, T.F., Ming, D.W., Blake, D.F., Vaniman, D.T., Bish, D.L., Chipera, S.J., Morrison, S.M., Downs, R.T., 2014. Ferrian saponite from the Santa Monica Mountains (California, USA, Earth): Characterization as an analog for clay minerals on Mars with application to Yellowknife Bay in Gale Crater. Am. Mineral. 99 (11-12), 2234-2250.

Treiman, A.H., Bish, D.L., Vaniman, D.T., Chipera, S.J., Blake, D.F., Ming, D.W., Morris, R.V., Bristow, T.F., Morrison, S.M., Baker, M.B., Rampe, E.B., Downs, R.T., Filiberto, J., Glazner, A.F., Gellert, R., Thompson, L.M., Schmidt, M.E., Le Deit, L., Wiens, R.C., McAdam, A.C., Achilles, C.N., Edgett, K.S., Farmer, J.D., Fendrich, K.V., Grotzinger, J.P., Gupta, S., Morookian, J.M., Newcombe, M.E., Rice, M.S., Spray, J.G., Stolper, E.M., Sumner, D.Y., Vasavada, A.R., Yen, A.S., 2016. Mineralogy, provenance, and diagenesis of a potassic basaltic sandstone on Mars: CheMin X-ray diffraction of the Windjana sample (Kimberley area, Gale crater). J. Geophys. Res. - Planets 121 (1), 75-106.

Trüper, H.G., 1982. Microbial processes in the sulfur cycle through time. Mineral Deposits and the Evolution of the Biosphere. Springer, Berlin, Heidelberg, pp. 5-30.

VanBommel, S.J., Gellert, R., Berger, J.A., Campbell, J.L., Thompson, L.M., Edgett, K.S., McBride, M.J., Minitti, M.E., Pradler, I., Boyd, N.I., 2016. Deconvolution of distinct lithology chemistry through oversampling with the Mars Science Laboratory Alpha Particle X-ray Spectrometer. Xray Spectrom. 45, 155-161.

Vaniman, D.T., Bish, D.L., Ming, D.W., Bristow, T.F., Morris, R.V., Blake, D.F., Chipera, S.J., Treiman, A.H., Rampe, E.B., Rice, M., Achilles, C.N., Grotzinger, J.P., McLennan, S.M., Williams, J., Bell III, J.F., Newsom, H.E., Downs, R.T., Maurice, S., Sarrazin, P., Yen, A.S., Morookian, J.M., Farmer, J.D., Stack, K., Milliken, R.E., Ehlmann, B.L., Sumner, D.Y., Berger, G., Crisp, J.A., Hurowitz, J.A., Anderson, R., Des Marais, D.J., Stolper, E.M., Edgett, K.S., Gupta, S., Spanovich, N., MSL Science Team, 2014. Mineralogy of a mudstone at Yellowknife Bay, Gale crater, Mars. Science 343 (6169), 1243480.

Vaniman, D.T., Martínez, G.M., Rampe, E.B., Bristow, T.F., Blake, D.F., Yen, A.S., Ming, D.W., Rapin, W., Meslin, P.-Y., Morookian, J.M., Downs, R.T., Chipera, S.J., Morris R.V., Morrison, S.M., Treiman, A.H., Achilles, C.N., Robertson, K., Grotzinger, J.P., Hazen, R.M., Wiens, R.C., Sumner, D.Y., 2018. Gypsum, bassanite, and anhydrite at Gale crater, Mars. Am. Mineral. 103 (7), 1011-1020.

Vasavada, A.R., Grotzinger, J.P., Arvidson, R.E., Calef, F.J., Crisp, J.A., Gupta, S., Hurowitz, J., Mangold, N., Maurice, S., Schmidt, M.E., Wiens, R.C., Williams, R.M.E. Yingst, R.A., 2014. Overview of the mars science laboratory mission: Bradbury landing to Yellowknife Bay and beyond. J. Geophys. Res. - Planets 119 (6), 1134-1161.

Webster, C.R., Mahaffy, P.R., Atreya, S.K., Moores, J.E., Flesch, G.J., Malespin, C., McKay, C.P., Martinez, G., Smith, C.L., Martin-Torres, J., Gomez-Elvira, J., Zorzano, M.-P., Wong, M.H., Trainer, M.G., Steele, A., Archer Jr., D., Sutter, B., Coll, P.J., Freissinet, C., Meslin, P.-Y., Gough, R., House, C.H., Pavlov, A., Eigenbrode, J.L., Glavin, D.P., Pearson, J.C., Keymeulen, D., Christensen, L.E., Schwenzer, S.P., Navarro-Gonzalez, R., Pla-García, J., Rafkin, S.C., Vicente-Retortillo, Á., Kahanpää, H., Viudez-Moreiras, D., Smith, M.D., Harri, A.-M., Gezner, M., Hassler, D.M., Lemmon, M., Crisp, J., Sander, S.P., Zurek, R.W., Vasavada, A.R., 2018. Background levels of methane in Mars' atmosphere show strong seasonal variations. Science 360 (6393), 1093-1096.

Wellington, D.F., Bell III, J.F., Johnson, J.R., Kinch, K.M., Rice, M.S., Godber, A., Ehlmann, B.L., Fraeman, A.A., Hardgrove, C., the MSL Science Team, 2017a. Visible to near-infrared MSL/Mastcam multispectral imaging: Initial results from select highinterest science targets within Gale Crater, Mars. Am. Mineral. 102 (6), 1202-1217.

Wellington, D.F., Bell III, J.F., Ehlmann, B., Fraeman, A.A., Horgan, B.H.N., Johnson, J.R., Rice, M.S., 2017b. Spectral variability along Curiosity's traverse through the Murray formation from Mars science Laboratory/Mastcam multispectral observations. GSA Meeting With Abstracts (Cordilleran Section) (No. 12-7).

Wiens, R.C., Maurice, S., Barraclough, B., Saccoccio, M., Barkley, W.C., Bell III, J.F., Bender, S., Bernardin, J., Blaney, D., Blank, J., Bouyé, M., Bridges, N., Cais, P., Clanton, R.C., Clark, B., Clegg, S., Cousin, A., Cremers, D., Cros, A., DeFlores, L., Delapp, D., Dingler, R., d'Uston, C., Dyar, M.D., Elliott, T., Enemark, D., Fabre, C. Flores, M., Forni, O., Gasnault, O., Hale, T., Hays, C., Herkenhoff, K., Kan, E., Kirkland, L., Kouach, D., Landis, D., Langevin, Y., Lanza, N., LaRocca, F., Lasue, J., Latino, J., Limonadi, D., Lindensmith, C., Little, C., Mangold, N., Manhes, G., Mauchien, P., McKay, C., Miller, E., Mooney, J., Morris, R.V., Morrison, L., Nelson, T., Newsom, H., Ollila, A., Ott, M., Pares, L., Perez, R., Poitrasson, F., Provost, C., Reiter, J.W., Roberts, T., Romero, F., Sautter, V., Salazar, S., Simmonds, J.J., Stiglich, R., Storms, S., Striebig, N., Thocaven, J.-J., Trujillo, T., Ulibarri, M., Vaniman, D., Warner, N., Waterbury, R., Whitaker, R., Witt, J., Wong-Swanson, B., 2012. The ChemCam instrument suite on the Mars Science Laboratory (MSL) rover: body unit and combined system tests. Space Sci. Rev. 170 (1-4), 167-227.

Wiens, R.C., Maurice, S., MSL Science Team, 2015a. ChemCam: chemostratigraphy by the first Mars microprobe. Elements 11 (1), 33-38.

Wiens, R.C., Maurice, S., Gasnault, O., Clegg, S., Fabre, C., Nachon, M., Rubin, D., Goetz, W., Mangold, N., Schröder, S., Rapin, W., Milliken, R., Fairen, A.G., Oehler, D., Forni, O., Sautter, V., Blaney, D., Le Mouelic, S., Anderson, R.B., Cousin, A., Vasavada, A., Grotzinger, J., the MSL Science Team, 2015b. Centimeter to decimeter size spherical and cylindrical features in Gale crater sediments. Lunar and Planetary Science Conference (Vol. 46)

Wiens, R.C., Rubin, D.M., Goetz, W., Fairén, A.G., Schwenzer, S.P., Johnson, J.R., Milliken, R.E., Clark, B., Mangold, N., Stack, K.M., Oehler, D., Rowland, S., Chan, M., Vaniman, D., Maurice, S., Gasnault, O., Rapin, W., Schroeder, S., Clegg, S., Forni, O., 
Blaney, D., Cousin, A., Payré, V., Fabre, C., Nachon, M., Le Mouelic, S., Sautter, V., Johnstone, S., Calef, F., Vasavada, A.R., Grotzinger, J.P., 2017. Centimeter to decimeter hollow concretions and voids in Gale crater sediments, Mars. Icarus 289, 144-156.

Williams, R.M.E., Grotzinger, J.P., Dietrich, W.E., Gupta, S., Sumner, D.Y., Wiens, R.C. Mangold, N., Malin, M.C., Edgett, K.S., Maurice, S., Forni, O., Gasnault, O., Ollila, A., Newsom, H.E., Dromart, G., Palucis, M.C., Yingst, R.A., Anderson, R.B., Herkenhoff, K.E., Le Mouelic, S., Goetz, W., Madsen, M.B., Koefoed, A., Jensen, J.K., Bridges, J.C., Schwenzer, S.P., Lewis, K.W., Stack, K.M., Rubin, D., Kah, L.C., Bell III, J.F., Farmer, J.D., Sullivan, R., Van Beek, J., Blaney, D.L., Pariser, O., Deen, R.G., MSL Science Team, 2013. Martian fluvial conglomerates at Gale crater. Science 340 (6136), 1068-1072.

Wiseman, S.M., Arvidson, R.E., Morris, R.V., Poulet, F., Andrews-Hanna, J.C., Bishop, J.L., Murchie, S.L., Seelos, F.P., Des Marais, D., Griffes, J.L., 2010. Spectral and stratigraphic mapping of hydrated sulfate and phyllosilicate-bearing deposits in northern Sinus Meridiani, Mars. J. Geophys. Res. - Planets 115 (E7).

Wray, J.J., Noe Dobrea, E.Z., Arvidson, R.E., Wiseman, S.M., Squyres, S.W., McEwan, A.S., Mustard, J.F., Murchie, S.L., 2009. Phyllosilicates and sulfates in Endeavor crater, Meridiani Planum, Mars. Geophys. Res. Lett. 36. https://doi.org/10.1029/ 2009GL040734.
Yen, A.S., Ming, D.W., Vaniman, D.T., Gellert, R., Blake, D.F., Morris, R.V., Morrison, S.M., Bristow, T.F., Chipera, S.J., Edgett, K.S., Treiman, A.H., Clark, B.C., Downs, R.T., Farmer, J.D., Grotzinger, J.P., Rampe, E.B., Schmidt, M.E., Sutter, B., Thompson, L.M., MSL Science Team, 2017. Multiple stages of aqueous alteration along fractures in mudstone and sandstone strata in Gale Crater, Mars. Earth Planet. Sci. Lett. 471, 186-198.

Yen, A.S., Morris, R.V., Ming, D.W., Schwenzer, S., Sutter, B., Vaniman, D.T., Treiman, A.H., Gellert, R., Achilles, C.N., Berger, J.A., Blake, D.F., Boyd, N.I., Bristow, T., Chipera, S., Clark, B.C., Craig, P.I., Downs, R.T., Franz, H.B., Gabriel, T., McAdam, A.C., Morrison, S.M., O'Connell-Cooper, C.D., Rampe, E.B., Schmidt, M.E.,

Thompson, L.M., VanBommel, S.J., 2020. High-temperature hydrothermal history at Gale crater, Mars. Geophys. Res. Lett Submitted for publication.

Yingst, R.A., Kah, L.C., Palucis, M., Williams, R.M.E., Garvin, J., Bridges, J.C., Bridges, N., Deen, R.G., Farmer, J., Gasnault, O., Goetz, W., Hamilton, V.E., Hipkin, V., Jensen, J.K., King, P.L., Foefoed, A., Le Mouélic, S.P., Madsen, M.B., Mangold, N., MartinezFrias, J., Maurice, S., McCartney, E.M., Newsom, H., Pariser, O., Sautter, V.H., Wiens, R.C., 2013. Characteristics of pebble-and cobble-sized clasts along the Curiosity rover traverse from Bradbury Landing to Rocknest. J. Geophys. Res. - Planets 118 (11), $2361-2380$. 